\title{
The Fracture Toughness of Nuclear Graphite Grades
}

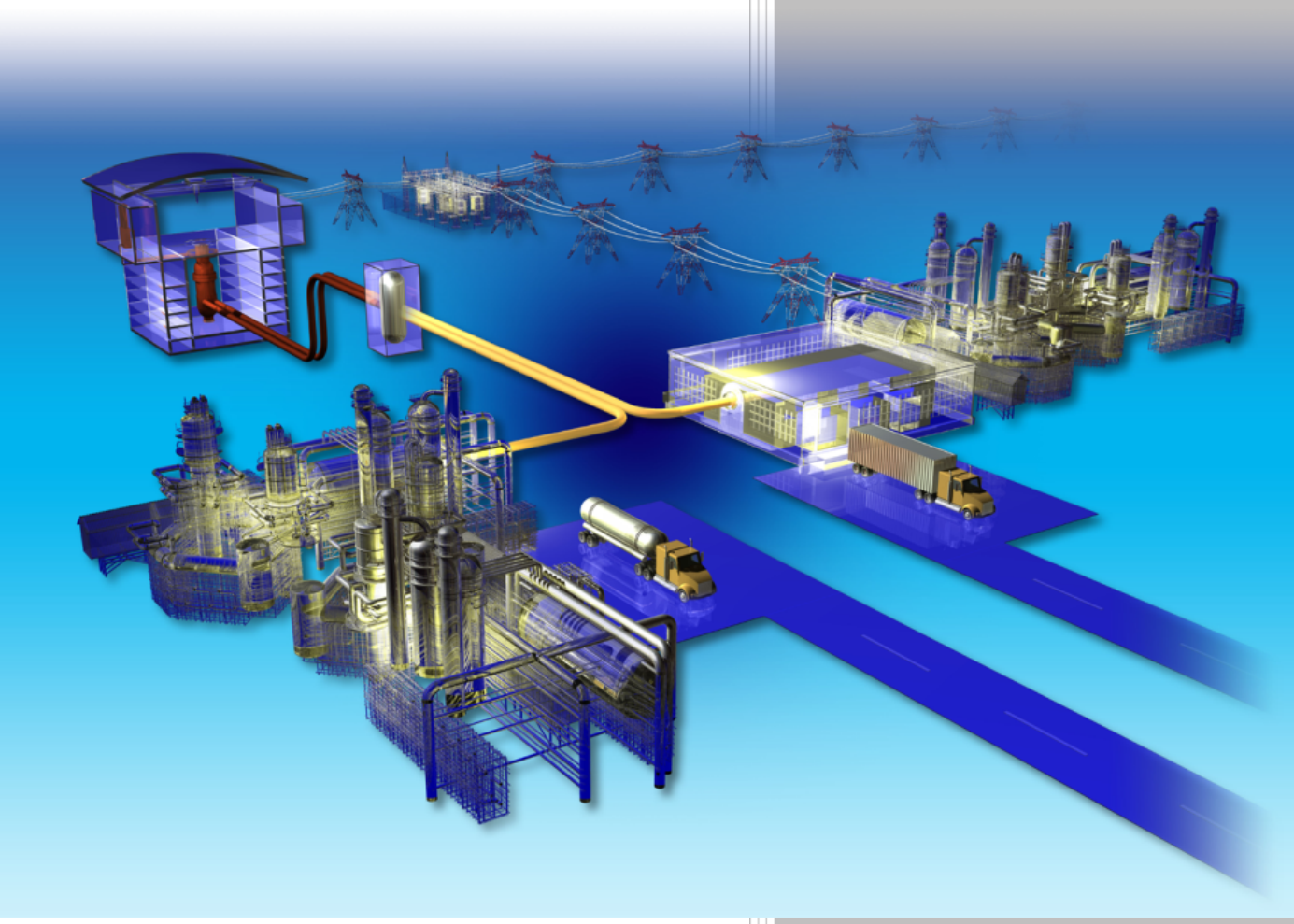

Tim Burchell, Don Erdmann III Rick R. Lowden James Hunter Cara Hannel

November 2016 


\title{
DOCUMENT AVAILABILITY
}

Reports produced after January 1, 1996, are generally available free via US Department of Energy (DOE) SciTech Connect.

Website http://www.osti.gov/scitech/

Reports produced before January 1, 1996, may be purchased by members of the public from the following source:

\author{
National Technical Information Service \\ 5285 Port Royal Road \\ Springfield, VA 22161 \\ Telephone 703-605-6000 (1-800-553-6847) \\ TDD 703-487-4639 \\ Fax 703-605-6900 \\ E-mail info@ntis.gov \\ Website http://www.ntis.gov/help/ordermethods.aspx
}

Reports are available to DOE employees, DOE contractors, Energy Technology Data Exchange representatives, and International Nuclear Information System representatives from the following source:

Office of Scientific and Technical Information

PO Box 62

Oak Ridge, TN 37831

Telephone 865-576-8401

Fax 865-576-5728

E-mail reports@osti.gov

Website http://www.osti.gov/contact.html

This report was prepared as an account of work sponsored by an agency of the United States Government. Neither the United States Government nor any agency thereof, nor any of their employees, makes any warranty, express or implied, or assumes any legal liability or responsibility for the accuracy, completeness, or usefulness of any information, apparatus, product, or process disclosed, or represents that its use would not infringe privately owned rights. Reference herein to any specific commercial product, process, or service by trade name, trademark, manufacturer, or otherwise, does not necessarily constitute or imply its endorsement, recommendation, or favoring by the United States Government or any agency thereof. The views and opinions of authors expressed herein do not necessarily state or reflect those of the United States Government or any agency thereof. 


\title{
THE FRACTURE TOUGHNESS OF NUCLEAR GRAPHITE GRADES
}

\author{
Tim Burchell \\ Don Erdmann III \\ Rick R. Lowden \\ James Hunter \\ Cara Hannel
}

Date Published: November 2016

Prepared by

OAK RIDGE NATIONAL LABORATORY

Oak Ridge, TN 37831-6283

managed by

UT-BATTELLE, LLC

for the

US DEPARTMENT OF ENERGY

under contract DE-AC05-00OR22725 



\section{Contents}

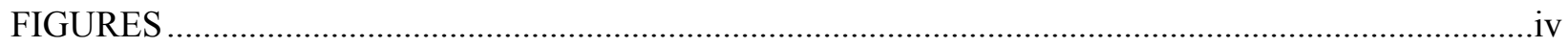

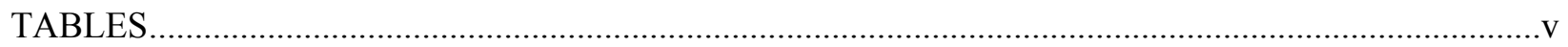

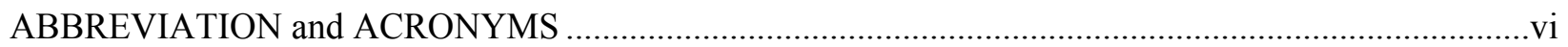

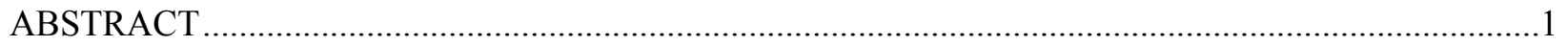

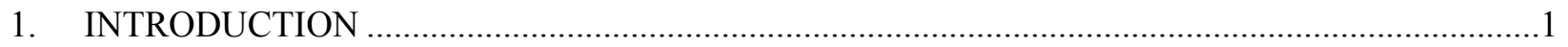

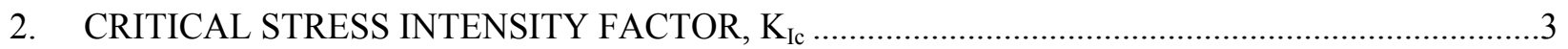

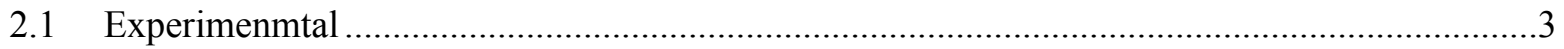

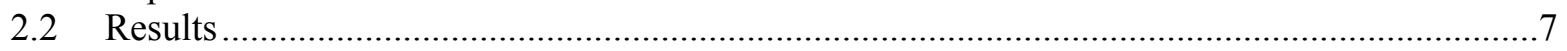

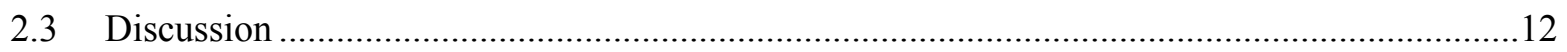

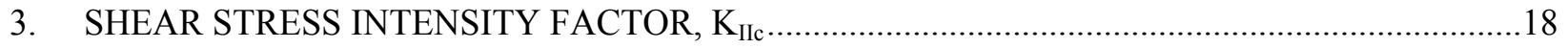

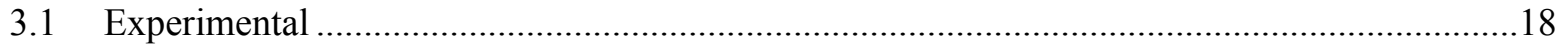

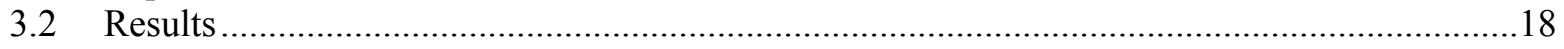

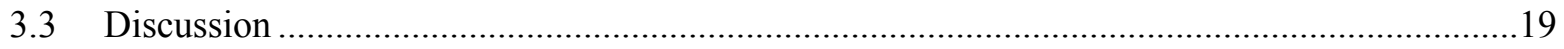

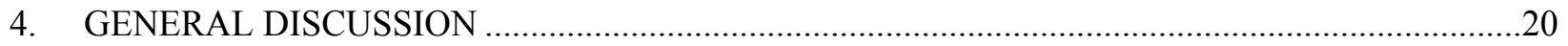

4.1 Application of fracture mechnics in ASTM standards and specifications ................................20

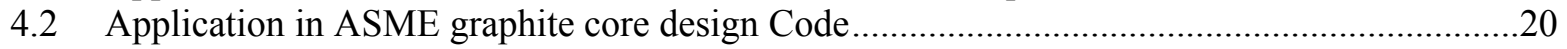

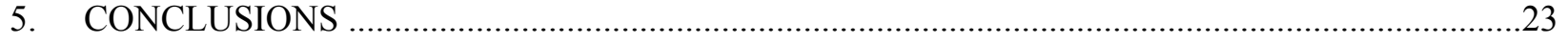

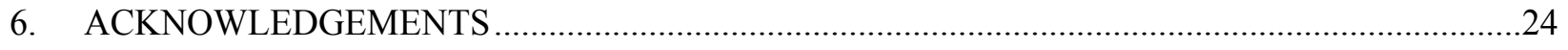

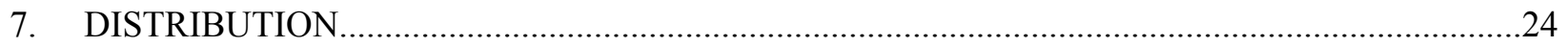

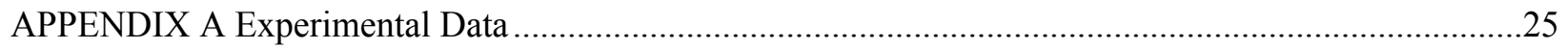

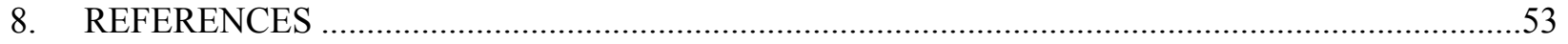




\section{FIGURES}

Figure 1 Specimen configuration showing dimensions L, W, B, and a.............................................

Figure 2 Typical SENB specimen showing the notching process ...................................................

Figure 3 Profilometry technique used to determine notch dimensions and standard conformity .................5

Figure 4 SENB - specimen under test showing the test configuration and AE probe locations...................6

Figure 5 AE Probe frequency response curve ${ }^{9}$..................................................................................

Figure 6 Load-time and cumulative AE counts-time curves for grade 2114 Block 2 specimen WG

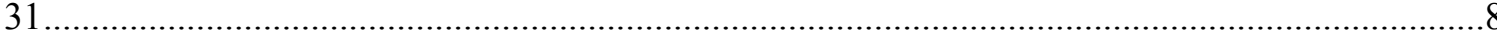

Figure 7 Load-time and cumulative AE counts-time curves for grade 2114 Block 2 specimen AG

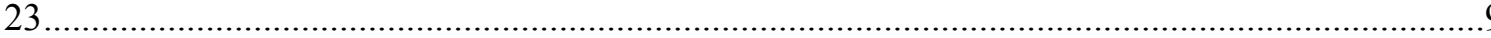

Figure 8 Load-time and cumulative AE counts-time curves for grade IG-110 specimen 22 ....................9

Figure 9 Load-time and cumulative AE counts-time curves for grade PCEA specimen $\mathrm{WG} \mathrm{K}_{\mathrm{Ic}}$ 118

Figure 10 Load-time and cumulative AE counts-time curves for grade PCEA specimen AG KIc 75

Figure 11 Load-time and cumulative AE counts-time curves for grade NBG-18 specimen 3B perp 10

Figure 12 Load-time and cumulative AE counts-time curves for grade NBG-18 specimen 3B Par 15

Figure 13 Variation of Critical Stress Intensity Factor with the graphite filler particle size

Figure 14 Variation of cumulative AE counts at maximum load, P, with the graphite filler particle size $(\mathrm{mm})$

Figure 15 Variation of cumulative AE counts at fracture end load with the graphite filler particle size $(\mathrm{mm})$

Figure 16 Variation of cumulative AE counts (i) at max load P, and (ii) at fracture end load with Critical Stress Intensity Factor

Figure 17 Variation of cumulative AE counts at maximum load, P, with the Log of graphite filler particle size $(\mathrm{mm})$

Figure 18 Variation of Critical Stress Intensity Factor with the graphite fracture process zone size..........17

Figure 19 Calculated probability of failure for nuclear graphite core components as a function of

Grain Size, mm. 


\section{TABLES}

Table 1 Fracture testing chronology for the test data reported here ....................................................2

Table 2 Summary of mean and St.Dev. for $\mathrm{K}_{\mathrm{Ic}}$ and $\mathrm{AE}$ data for the grades examined here....................... 7

Table $3 \mathrm{~K}_{\mathrm{Ic}}$ and calculated process zone size, $\mathrm{PZ}$, (radius) for the graphite grades examined here ..............8

Table 4 Summary $K_{I c}$ and $K_{\text {IIc }}$ data for the specimens tested here (note, in the case of the PCEA

(PAR) specimens and the NBG-18 (WG) specimens our prior data is included or

reported,

Table 5 Mean values, Standard deviation and [mean-(3*St. Dev.)] values ............................................20

Table 6 Existing and Proposed new $\mathrm{V}_{\mathrm{m}}$ for the ASME Sect III, Div. 5 Graphite code (HHA) ..................23

Table $7 \mathrm{~K}_{\mathrm{Ic}}$ and AE data for grade 2114, WG specimen (AG fracture orientation) .................................26

Table $8 \mathrm{~K}_{\mathrm{Ic}}$ and AE data for grade 2114, AG specimen (WG fracture orientation) .................................29

Table $9 \mathrm{~K}_{\mathrm{Ic}}$ and AE data for grade IG-110 (Graphite assumed to be isotropic).......................................32

Table $10 \mathrm{~K}_{\mathrm{Ic}}$ and AE data for grade PCEA, WG specimen (AG fracture orientation) ..............................34

Table $11 \mathrm{~K}_{\mathrm{Ic}}$ and AE data for grade PCEA, AG specimen (WG fracture orientation) ..............................39

Table $12 \mathrm{~K}_{\mathrm{Ic}}$ and AE data for grade NBG-18, AG specimen-perpendicular to long axis of billet

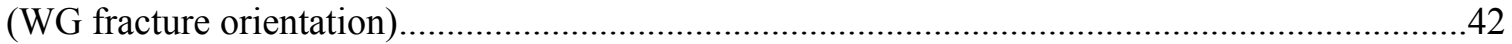

Table $13 \mathrm{~K}_{\mathrm{Ic}}$ and $\mathrm{AE}$ data for grade NBG-18, WG specimen-parallel to long axis of billet (AG

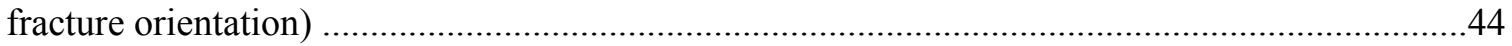

Table $14 \mathrm{~K}_{\mathrm{IIc}}$ data for grade PCEA, specimen cut parallel to billet long axis or extrusion direction ...........46

Table $15 \mathrm{~K}_{\mathrm{IIC}}$ data for PCEA, specimens cut perpendicular to the billet long axis or extrusion

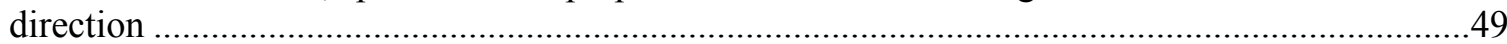

Table $16 \mathrm{~K}_{\mathrm{IIc}}$ data for IG-110, isostatically pressed fine-grained graphite .............................................51 


\section{ABBREVIATION AND ACRONYMS}

$\begin{array}{ll}\text { AE } & \text { acoustic emission } \\ \text { AG } & \text { against grain } \\ \text { ASME } & \text { American Society for Mechanical Engineers } \\ \text { ASTM } & \text { American Society for Testing of Materials } \\ \text { B\&PV } & \text { Boiler \& Pressure Vessel } \\ \text { CNSR } & \text { Chevron Notched Short Rod } \\ \text { DENC } & \text { Double Edge Notched Compression } \\ \text { FEM } & \text { Finite Element Analysis } \\ \text { K }_{\text {Ic }} & \text { critical stress intensity factor, or facture toughness } \\ \text {K}_{\text {IIc }} & \text { critical shear stress intensity factor, or shear facture toughness } \\ \text { SENB } & \text { Single Edge Notched Beam } \\ \text { SINAP } & \text { Shanghai Institute of Applied Physics } \\ \text { PZ } & \text { Process Zone } \\ \text { WG } & \text { with grain }\end{array}$




\begin{abstract}
New measurements of graphite mode I critical stress intensity factor, $\mathrm{K}_{\mathrm{Ic}}$ (commonly referred to as the fracture toughness) and the mode II critical shear stress intensity, $\mathrm{K}_{\text {IIc }}$, are reported and compared with prior data for $\mathrm{K}_{\mathrm{Ic}}$ and $\mathrm{K}_{\mathrm{IIc}}$. The new data are for graphite grades PCEA, IG-110 and 2114. Variations of $\mathrm{K}_{\mathrm{Ic}}$ and acoustic emission (AE) data with graphite texture are reported and discussed. The Codes and Standards applications of fracture toughness, $\mathrm{K}_{\mathrm{Ic}}$, data are also discussed. A specified minimum value for nuclear graphite $\mathrm{K}_{\mathrm{Ic}}$ is recommended.
\end{abstract}

\title{
1. INTRODUCTION
}

Quantitative measures of graphite fracture are not widely used in nuclear graphite technology, perhaps because representative toughness values vary with specimen geometry/measurement method $^{1}$ and with the specimen $\operatorname{size}^{2}$, this despite the fact that the critical stress intensity factor, $\mathrm{K}_{\mathrm{Ic}}$, can vary by $\sim 50 \%$ from grade to grade. For example, the critical stress intensity factor for grade IG-110 was reported ${ }^{1}$ with values from 0.83 to $1.16 \mathrm{MPa} \vee \mathrm{m}$, when measured on six different specimen geometries. Romanoski and Burchell ${ }^{2}$, using just the chevron notched short rod geometry (CNSR), reported an increase in $\mathrm{K}_{\mathrm{Ic}}$ of $>20 \%$ when the CNSR specimen diameter increased from $12.7 \mathrm{~mm}$ to $25.4 \mathrm{~mm}$ for the three graphite grades they tested $(\mathrm{H}-451, \mathrm{~S}-2020$ and IG-110).

The recent adoption of an ASTM Standard Test Method for the Determination of Fracture Toughness of Graphite at Ambient Temperature ${ }^{3}$ has allowed for the use of standard values and consequently the adoption of $\mathrm{K}_{\mathrm{Ic}}$ minimums in ASTM Standard Specifications for nuclear graphite ${ }^{4,5}$. The proposed use of fracture toughness in codes and standards is discussed in section 4 General Discussion.

The standard method ${ }^{3}$ prescribes the use of the single edge notched beam (SENB) specimen and test geometry. It mandates the specimen minimum size and loading conditions, and gives details of the notch sharpening methodology and required notch dimensions. As noted in the experimental section (2.1) all $\mathrm{K}_{\mathrm{Ic}}$ testing reported here was in accordance with the ASTM standard for graphite fracture toughness ${ }^{3}$ and all testing was performed on identical geometry specimen and test conditions. Thus, the variations in the $\mathrm{K}_{\mathrm{Ic}}$ data reported and discussed here can only be attributed to changes of the grade (i.e., to the texture changes between different grades).

In prior work Burchell and Strizak ${ }^{6,7}$ studied nuclear graphite grade PCEA to determine the effect of neutron irradiation on the critical stress intensity factor, $\mathrm{K}_{\mathrm{Ic}}$. Although the SENB-type specimen was used and the specimen was compliant with ASTM D7779 3 a smaller volume sample was required for the irradiations. The $\mathrm{K}_{\mathrm{Ic}}$ value of $0.97 \mathrm{MPa} \sqrt{\mathrm{m}}$ for these small specimens is significantly smaller than the $1.33 \mathrm{MPa} \vee \mathrm{m}$ reported in the current work, suggesting the SENB geometry suffers significantly from a specimen size effect.

Yang et $\mathrm{al}^{8}$ reported a study of graphite SENB specimen size on the absolute value of $\mathrm{K}_{\mathrm{Ic}}$ measured. They tested a fine-grain $(20 \mu \mathrm{m})$, isostatically pressed graphite (grade SNG742) and obtained $\mathrm{K}_{\mathrm{Ic}}=1.12$ from specimens of identical geometry and size as tested here. However, a 
reduced value of $\mathrm{K}_{\mathrm{Ic}}=0.76 \mathrm{MPa} \sqrt{\mathrm{m}}$ was measured for smaller volume samples measuring $23 \times 2$ $\mathrm{x} 1.5 \mathrm{~mm}$, confirming the observation that the value of $\mathrm{K}_{\mathrm{Ic}}$ derived from an SENB specimen is subject to a significant size effect.

Additionally, Burchell and Strizak ${ }^{6,7}$ reported toughness was increased for specimens oriented in a with-grain direction (yielding an against-grain crack plane). Similar toughness change with changes to the sample orientation was also noted in the current study.

If the derived $\mathrm{K}_{\mathrm{Ic}}$ value is to be used for the purposes of grade comparison, quality control, or codes and standards activities the specimen geometry and size should be held constant.

The $\mathrm{K}_{\mathrm{Ic}}$ and $\mathrm{K}_{\mathrm{IIc}}$ data reported here were taken over a two year period. Table 1 reports the testing chronology for the data reported here.

\begin{tabular}{|c|c|c|c|c|c|}
\hline $\begin{array}{c}\text { Year } \\
\text { Tested }\end{array}$ & $\begin{array}{c}\text { Fracture } \\
\text { Measurement } \\
\text { type }\end{array}$ & $\begin{array}{l}\text { specimen } \\
\text { Geometry }\end{array}$ & Grade/Crack Orientation & $\begin{array}{l}\text { No. } \\
\text { specimens } \\
\text { Tested }\end{array}$ & $\begin{array}{l}\text { Total No. of } \\
\text { Specimens } \\
\text { for grade } \\
\text { and } \\
\text { Orientation }\end{array}$ \\
\hline \multicolumn{6}{|c|}{$\mathrm{K}_{\mathrm{Ic}}$ (SENB) } \\
\hline 2016 & $K_{\mathrm{Ic}}$ & SENB & $2114(A G)$ & 54 & 54 \\
\hline 2016 & $\mathrm{~K}_{\mathrm{Ic}}$ & SENB & 2114 (WG) & 55 & 55 \\
\hline 2016 & $\mathrm{~K}_{\mathrm{Ic}}$ & SENB & IG-110 & 32 & 32 \\
\hline 2015 & $\mathrm{~K}_{\mathrm{Ic}}$ & SENB & PCEA (AG) & 20 & \\
\hline 2016 & $K_{\mathrm{Ic}}$ & SENB & PCEA (AG) & 98 & 118 \\
\hline 2015 & $\mathrm{~K}_{\mathrm{Ic}}$ & SENB & PCEA (WG) & 37 & \\
\hline 2016 & $\mathrm{~K}_{\mathrm{Ic}}$ & SENB & PCEA (WG) & 36 & 73 \\
\hline 2015 & $\mathrm{~K}_{\mathrm{Ic}}$ & SENB & NBG-18WG (spec. PERP*) & 25 & 25 \\
\hline 2015 & $\mathrm{~K}_{\mathrm{Ic}}$ & SENB & NBG-18 AG (spec. PAR*) & 25 & 25 \\
\hline \multicolumn{6}{|c|}{$\mathrm{K}_{\text {III }}(\mathrm{DENC})$} \\
\hline 2016 & $\mathrm{~K}_{\text {Illc }}$ & DENC & IG-110 & 26 & 26 \\
\hline 2015 & $\mathrm{~K}_{\| \mathrm{ll}}$ & DENC & PCEA (PAR) & 8 & \\
\hline 2016 & $\mathrm{~K}_{\mathrm{Ilc}}$ & DENC & PCEA (PAR) & 51 & 59 \\
\hline 2015 & $\mathrm{~K}_{\| \mathrm{ll}}$ & DENC & PCEA (PERP) & 0 & \\
\hline 2016 & $\mathrm{~K}_{\| \mathrm{ll}}$ & DENC & PCEA (PERP) & 24 & 24 \\
\hline 2015 & $\mathrm{~K}_{\mathrm{IIc}}$ & DENC & NBG-18 WG (spec. PERP*) & 10 & 10 \\
\hline $2015 / 16$ & $\mathrm{~K}_{\text {IIc }}$ & DENC & NBG-18 AG (spec. PAR*) & 0 & 0 \\
\hline
\end{tabular}

*orientation w.r.t. long axis of billet 


\section{CRITICAL STRESS INTENSITY FACTOR, $\mathbf{K}_{\mathrm{Ic}}$}

\subsection{EXPERIMENMTAL}

The "Fracture Toughness" or Critical Stress Intensity Factor, $\mathrm{K}_{\mathrm{Ic}}$, was determined using the single edge notched beam (SENB) with the ASTM recommended size and geomtry ${ }^{3}$. The critical stress intensity factor, $\mathrm{K}_{\mathrm{Ic}}$, was calculated for three-point flexure with $5 \leq \mathrm{S} / \mathrm{W} \leq 10$, and $0.35 \leq \mathrm{a} / \mathrm{W} \leq 0.60$ using equation (1):

$$
K_{I c}=g\left[\frac{P_{\max } S 10^{-6}}{B W^{3 / 2}}\right]\left[\frac{3[a / W]^{1 / 2}}{2[1-a / W]^{3 / 2}}\right]
$$

Where:

$$
\begin{aligned}
& g=g(a / W) \\
& g=A_{o}+A_{1}(a / W)+A_{2}(a / W)^{2}+A_{3}(a / W)^{3}+A_{4}(a / W)^{4}+A_{5}(a / W)^{5}
\end{aligned}
$$

The coefficients for the factor, g, are shown in Table 1 of the ASTM standard or calculated from equation 2 .

Where:

$$
\begin{array}{ll}
\mathrm{K}_{\mathrm{Ic}} & =\text { fracture toughness }(\mathrm{MPa} \sqrt{\mathrm{m}}), \\
\mathrm{g}=\mathrm{g}(\mathrm{a} / \mathrm{W}) & =\text { function of the ratio a/W, } \\
\mathrm{P}_{\max } & =\text { maximum force }(\mathrm{N}), \\
\mathrm{S} & =\operatorname{support} \text { span }(\mathrm{m}) \\
\mathrm{B} & =\text { breadth }(\text { width }) \text { of the specimen }(\mathrm{m}), \\
\mathrm{W} & =\text { specimen depth }(\mathrm{m}), \text { and } \\
\mathrm{a} & =\text { notch depth }(\mathrm{m})
\end{array}
$$

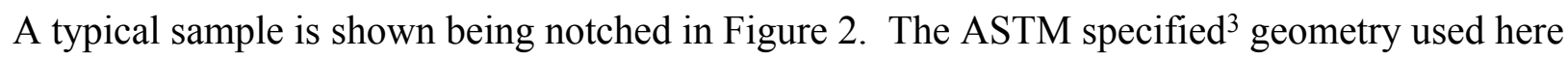
was the centrally slotted single edge notched beam (SENB) with dimensions of length $200 \mathrm{x}$ depth $20 \mathrm{x}$ width $15-\mathrm{mm}$ nominal.

The notch was sharpened with a scalpel (Figure 2), and had a nominal ligament length and notch depth of 12-mm and 8-mm, respectively. The notch was first cut to width $0.38-0.51-\mathrm{mm}$ with a machine tool slitting saw. The specimen utilized here thus had an $(\mathrm{a} / \mathrm{W})$ ratio of $\sim 0.4$ 


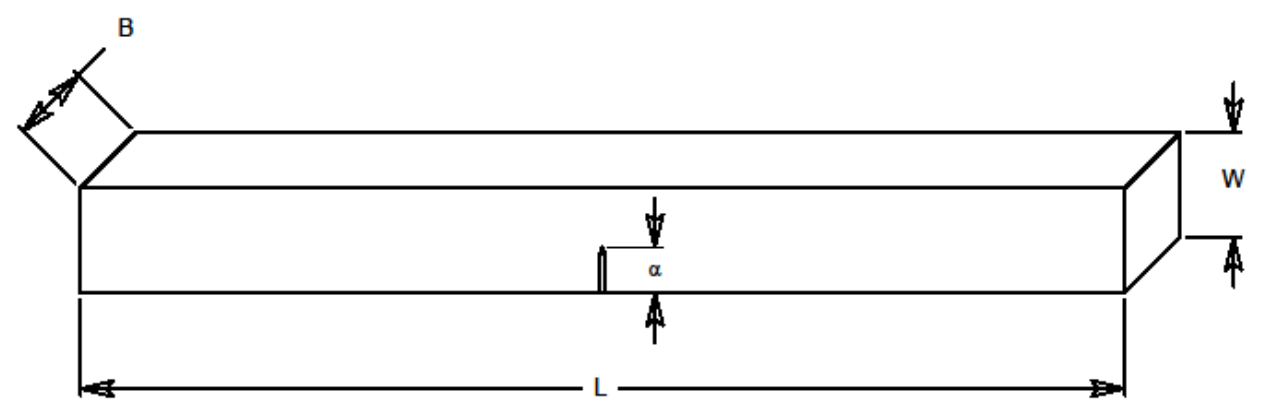

Figure 1 Specimen configuration showing dimensions L, W, B, and a.

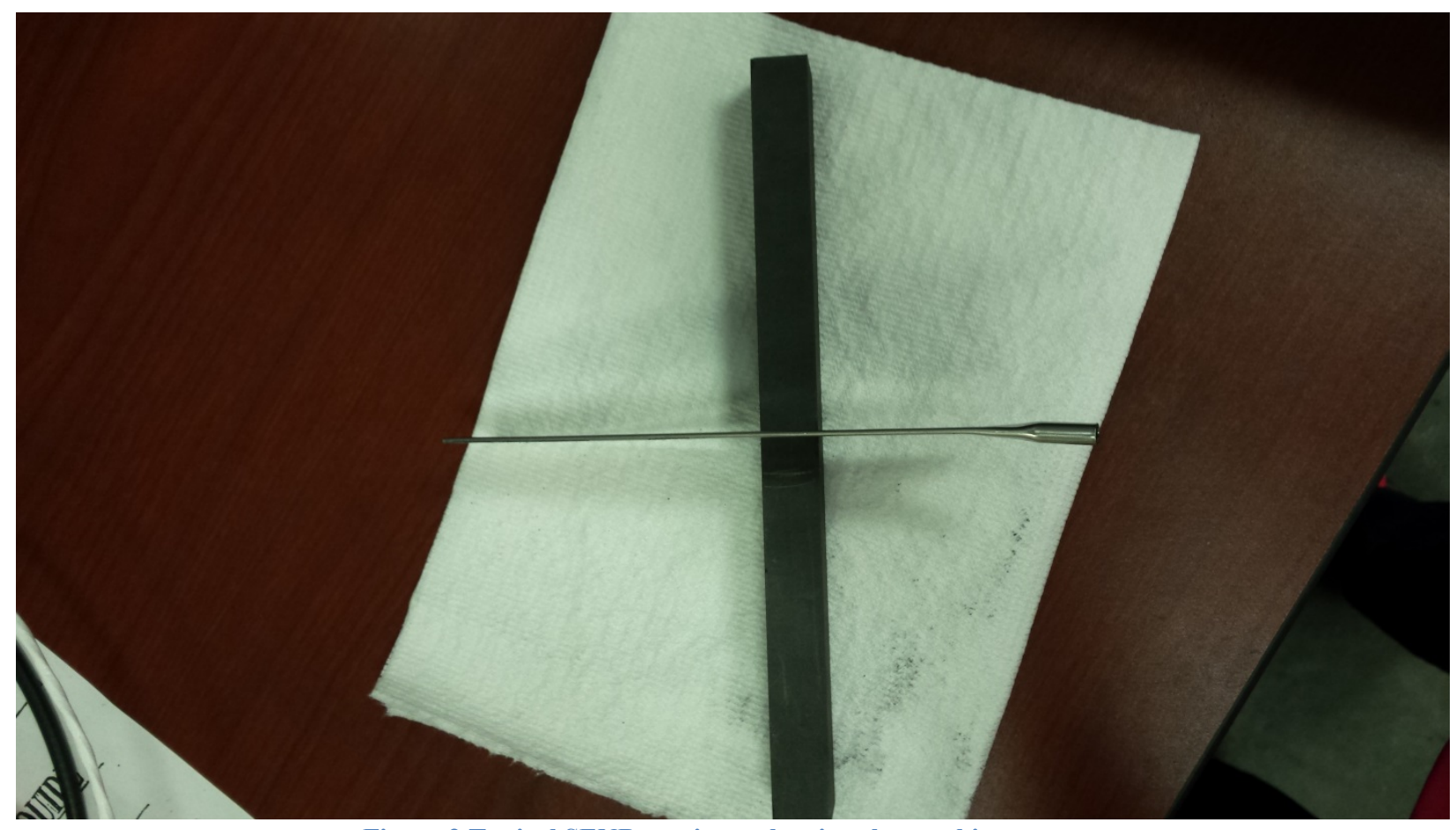

Figure 2 Typical SENB specimen showing the notching process

The specimens were each subjected to dimensional inspection after notching using calipers, micrometer, and shadowgraph profilometry (Figure 3 ) to ensure they conformed to the dimensions adopted here. 


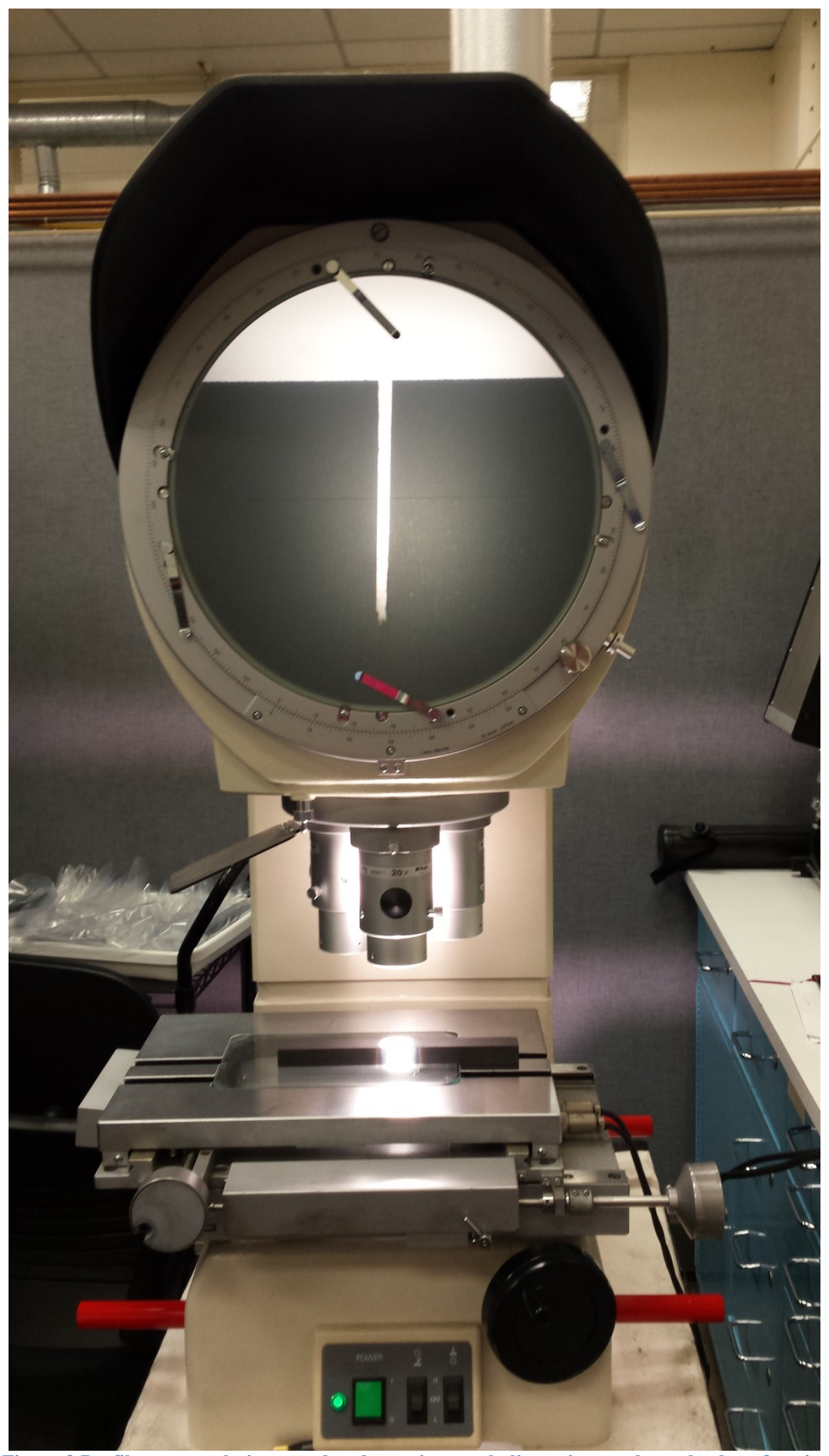

Figure 3 Profilometry technique used to determine notch dimensions and standard conformity 
Fracture testing was performed in 3-point bending, with the support span set to $160 \mathrm{~mm}$. Thus, the $\mathrm{S} / \mathrm{W}$ ratio was $\sim 8$ for this work (Figure 4). A uniform crosshead speed of $7.6 \mu \mathrm{m} / \mathrm{sec}$ or 0.46 $\mathrm{mm} / \mathrm{min}(0.0003 \mathrm{in} / \mathrm{sec})$ was used for all testing.

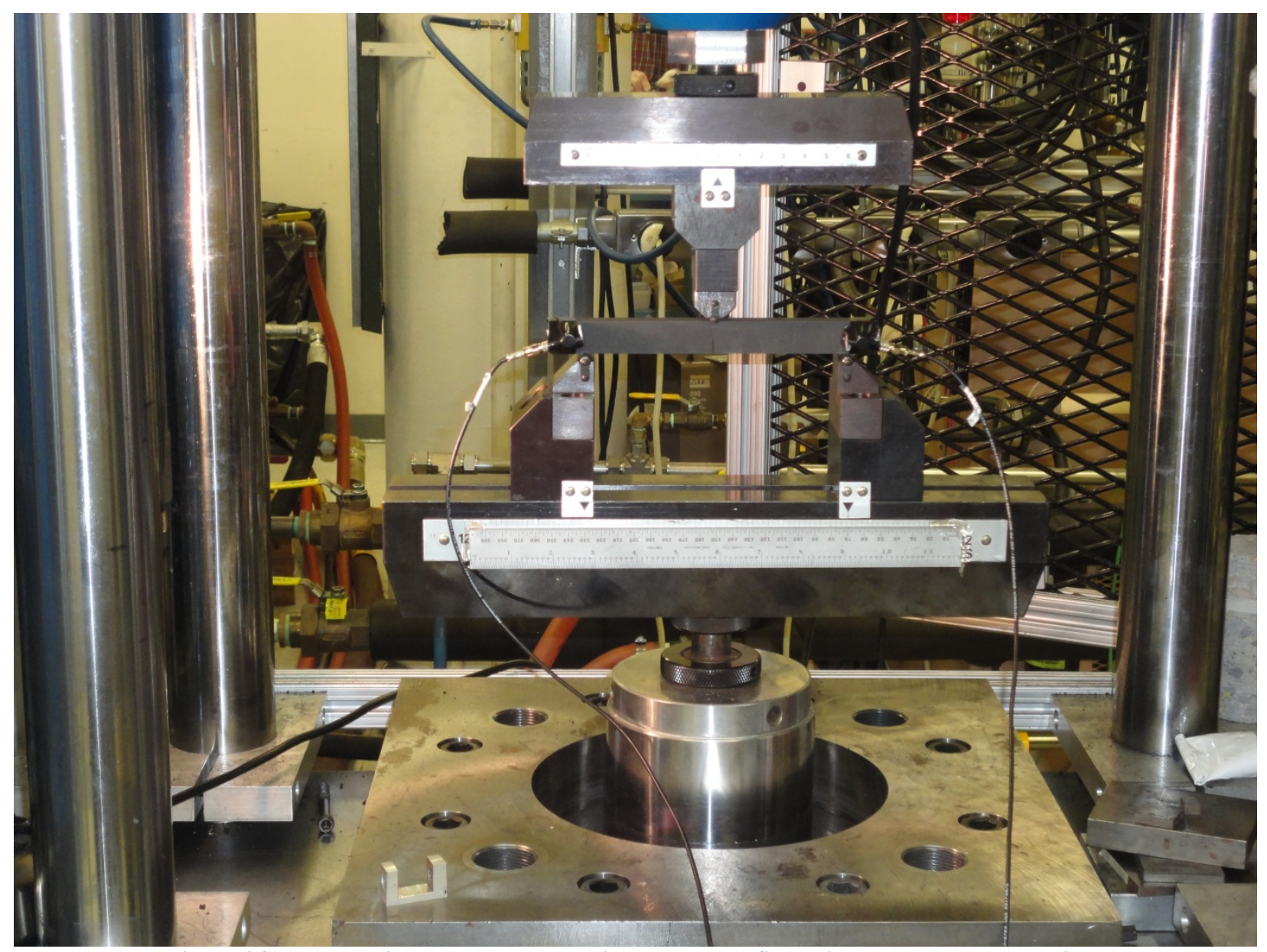

Figure 4 SENB - specimen under test showing the test configuration and AE probe locations

Acoustic Emission (AE) was monitored during specimen loading using a Vallen AMSY-6 multichannel system, running two channels with type AE105A high frequency probes ${ }^{9}$. The $8 \mathrm{~mm}$ dia. X $8 \mathrm{~mm}$ height, ceramic faced, stainless steel mini-probes had a frequency range from 450 to $1150 \mathrm{kHz}$ with a peak response frequency of $800 \mathrm{kHz}$. A representative probe frequency response is given in Figure 5. 


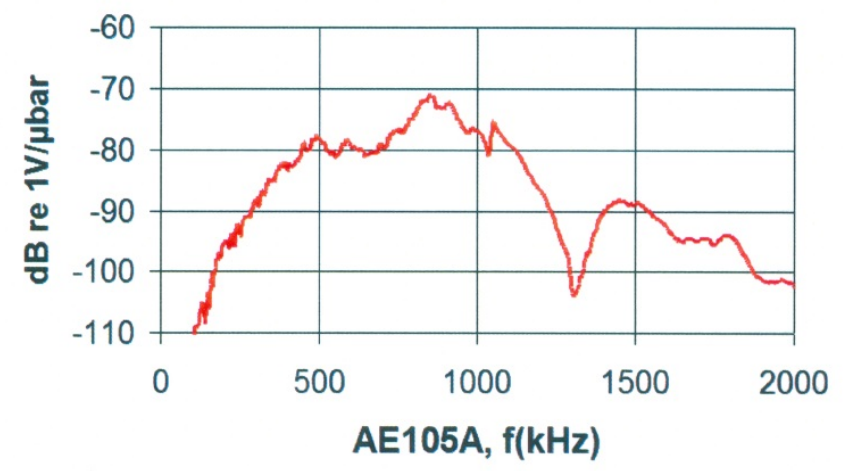

Figure 5 AE Probe frequency response curve 9

The two AE probes were placed equidistance from the notch on the center of the front face of the SENB specimen (Figure 4). Sonotrace 40 Ultrasonic Couplant was used between the specimen and the probes. The acoustic emission was recorded as the cumulative total of AE events at $\mathrm{P}$, the peak load used in the calculation of $\mathrm{K}_{\mathrm{Ic}}$, and the cumulative total of AE events at the facture load (this was arbitrarily taken to be at a load $50 \mathrm{~N}$ where a fracture end point was ill-defined).

\subsection{RESULTS}

The results of individual tests are given by grade in Appendix A along with the mean and standard deviations of the experimental values determined. The test data means are summarized in Table 2. Typical load-time plots for the graphite grades examined here are in Figure 6 to Figure 12. The load and cumulative AE counts are obtained from the digital data at the time intervals for $\mathrm{P}$ and the fracture end point was arbitrarily taken to be $50 \mathrm{~N}$ bending load (Figure 6 to Figure 12).

Table 2 Summary of mean and St.Dev, for $\mathbf{K}_{\text {Ic }}$ and AE data for the grades examined here

\begin{tabular}{|c|c|c|c|c|c|c|c|c|c|c|c|c|}
\hline $\begin{array}{l}\text { Grade/notch } \\
\text { orientation }\end{array}$ & Manufacturer & Forming method & $\begin{array}{c}\text { Filler Particle } \\
\text { Size, } \mathrm{mm}\end{array}$ & $\begin{array}{c}\text { Number of } \\
\text { specimens, } \\
n\end{array}$ & $\begin{array}{c}\text { Mean failure } \\
\text { load (N) }\end{array}$ & $\begin{array}{l}\text { S.D. failure } \\
\text { load (N) }\end{array}$ & $\begin{array}{c}\text { Mean Fracture } \\
\text { Toughness, KIc } \\
(\mathrm{MPa} V \mathrm{~m})\end{array}$ & $\begin{array}{c}\text { S.D. Fracture } \\
\text { Toughness, KIc } \\
(\mathrm{MPa} \sqrt{ } \mathrm{m})\end{array}$ & \begin{tabular}{|c|} 
Mean \\
cumulative \\
AE counts \\
at failure \\
(P) \\
\end{tabular} & \begin{tabular}{|c|} 
S.D. \\
cumulative \\
AE counts \\
at failure \\
(P)
\end{tabular} & $\begin{array}{c}\text { Mean } \\
\text { cumulative } \\
\text { AE counts at } \\
50 \mathrm{~N}\end{array}$ & $\begin{array}{c}\text { S.D. } \\
\text { cumulative } \\
\text { AE counts at } \\
50 \mathrm{~N}\end{array}$ \\
\hline $2114(\mathrm{AG})^{*}$ & Mercen & $\begin{array}{l}\text { Isostatically } \\
\text { molded }\end{array}$ & 0.013 & 54 & 149.62 & 4.62 & 1.15 & 0.04 & 1532 & 723 & 16813 & 8992 \\
\hline $2114(\mathrm{WG})^{*}$ & Mercen & $\begin{array}{l}\text { Isostatically } \\
\text { molded }\end{array}$ & 0.013 & 55 & 148.77 & 3.05 & 1.15 & 0.02 & 1503 & 171 & 15713 & 10229 \\
\hline IG-110 & Toyo Tanso & $\begin{array}{c}\text { Isostatically } \\
\text { molded }\end{array}$ & 0.02 & 32 & 138.7 & 3.9 & 1.07 & 0.03 & 585 & 446 & 17138 & 1738 \\
\hline PCEA (WG) & GrafTech & Extruded & 0.8 & 73 & 168.62 & 3.82 & 1.33 & 0.06 & 2101 & 1113 & 21845 & 5672 \\
\hline PCEA (AG) & GrafTech & Extruded & 0.8 & 118 & 186.17 & 5.14 & 1.48 & 0.06 & 2797 & 1419 & 27864 & 6273 \\
\hline NBG-18 (WG) & SGL Carbon & $\begin{array}{l}\text { Vibrationally } \\
\text { molded }\end{array}$ & 1.6 & 25 & 176.1 & 12.8 & 1.36 & 0.1 & 3578 & 2806 & 41693 & 16115 \\
\hline NBG-18 (AG) & SGL Carbon & $\begin{array}{c}\text { Vibrationally } \\
\text { molded }\end{array}$ & 1.6 & 25 & 182.7 & 6.6 & 1.41 & 0.05 & 4210 & 2174 & 54092 & 10826 \\
\hline
\end{tabular}

Table 3 provides calculated values of the fracture process zone ${ }^{12}$ (from equation 3 ) for the graphite grades examined. Manufacturer's data was used in some instances for this calculation. 
Table $3 \mathrm{~K}_{\mathrm{Ic}}$ and calculated process zone size, PZ, (radius) for the graphite grades examined here

\begin{tabular}{|c|c|c|c|c|c|c|c|}
\hline $\begin{array}{c}\text { Grade/notch } \\
\text { orientation }\end{array}$ & Manufacturer & Forming method & $\begin{array}{c}\text { Filler Particle } \\
\text { Size, } \mathrm{mm}\end{array}$ & $\begin{array}{l}\text { Ten. Stren. } \\
\text { (Manufact } \\
\text { data) } \mathrm{MPa}\end{array}$ & $\mathrm{KIc}(\mathrm{MPa} \sqrt{\mathrm{m}})$ & $P Z r_{c}(m)$ & $\mathrm{PZ} \mathrm{r}_{\mathrm{c}}(\mathrm{mm})$ \\
\hline $2114(\mathrm{WG})^{*}$ & Mercen & $\begin{array}{c}\text { Isostatically } \\
\text { molded }\end{array}$ & 0.013 & 34.7 & 1.15 & 0.00173 & 1.73 \\
\hline $2114(\mathrm{AG})^{*}$ & Mercen & $\begin{array}{c}\text { Isostatically } \\
\text { molded }\end{array}$ & 0.013 & 34.7 & 1.15 & 0.00173 & 1.73 \\
\hline IG-110 & Toyo Tanso & $\begin{array}{c}\text { Isostatically } \\
\text { molded }\end{array}$ & 0.02 & 24.5 & 1.07 & 0.00300 & 3.00 \\
\hline PCEA (WG) & GrafTech & Extruded & 0.8 & 16 & 1.33 & 0.01085 & 10.85 \\
\hline PCEA (AG) & GrafTech & Extruded & 0.8 & 20 & 1.48 & 0.00860 & 8.60 \\
\hline NBG-18 (WG)** & SGL Carbon & $\begin{array}{c}\text { Vibrationally } \\
\text { molded }\end{array}$ & 1.6 & 21 & 1.36 & 0.00659 & 6.59 \\
\hline NBG-18 $(\mathrm{AG})^{* *}$ & SGL Carbon & $\begin{array}{c}\text { Vibrationally } \\
\text { molded }\end{array}$ & 1.6 & 20 & 1.41 & 0.00781 & 7.81 \\
\hline$*$ & Tensile strength take & $n$ as $2 / 3$ of bend strength & & & & & \\
\hline$* *$ & Tensile Strength from & ORNL/TM-2010/219 Bill & et 60226356 & & & & \\
\hline
\end{tabular}

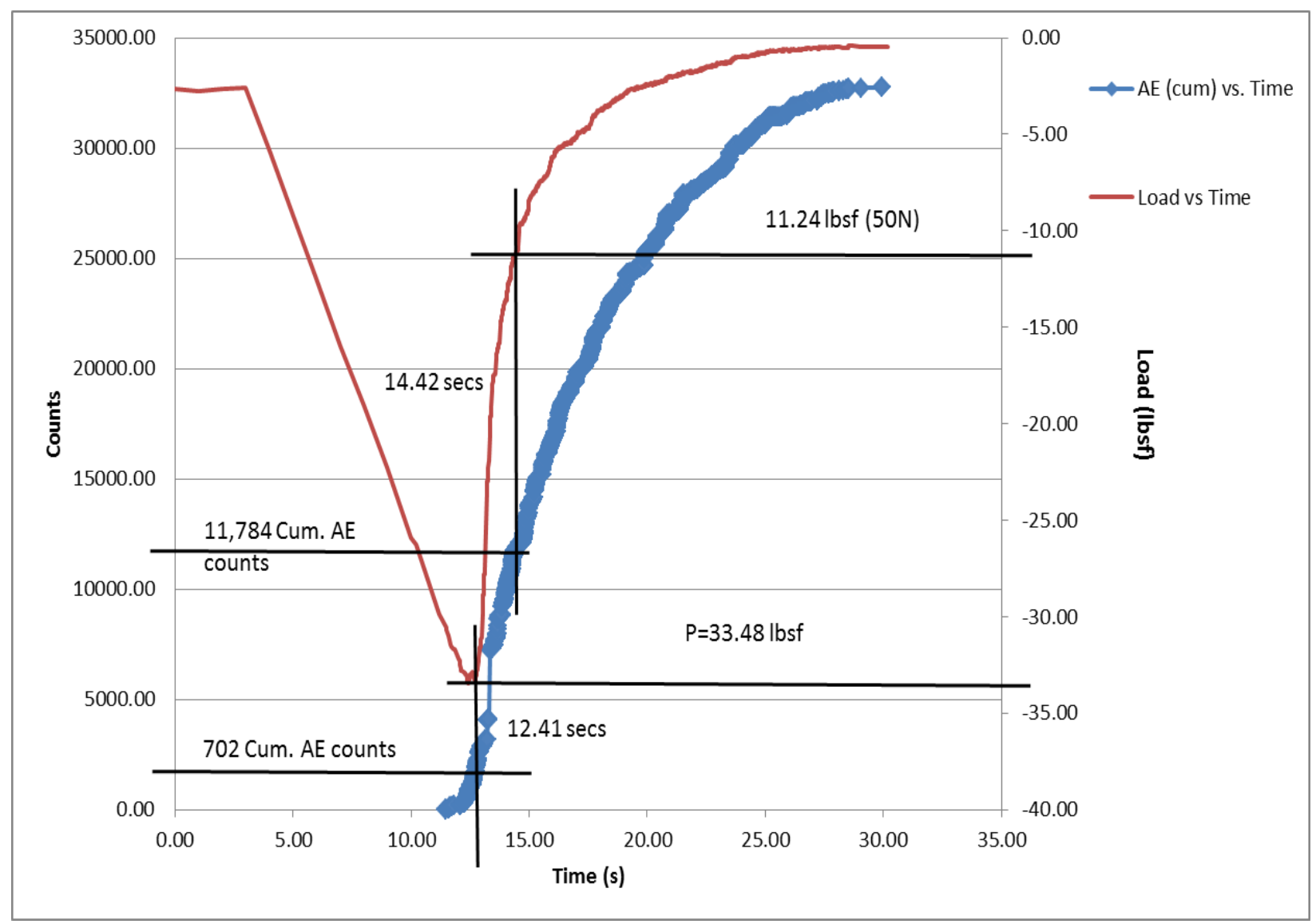

Figure 6 Load-time and cumulative AE counts-time curves for grade 2114 Block 2 specimen WG 31 


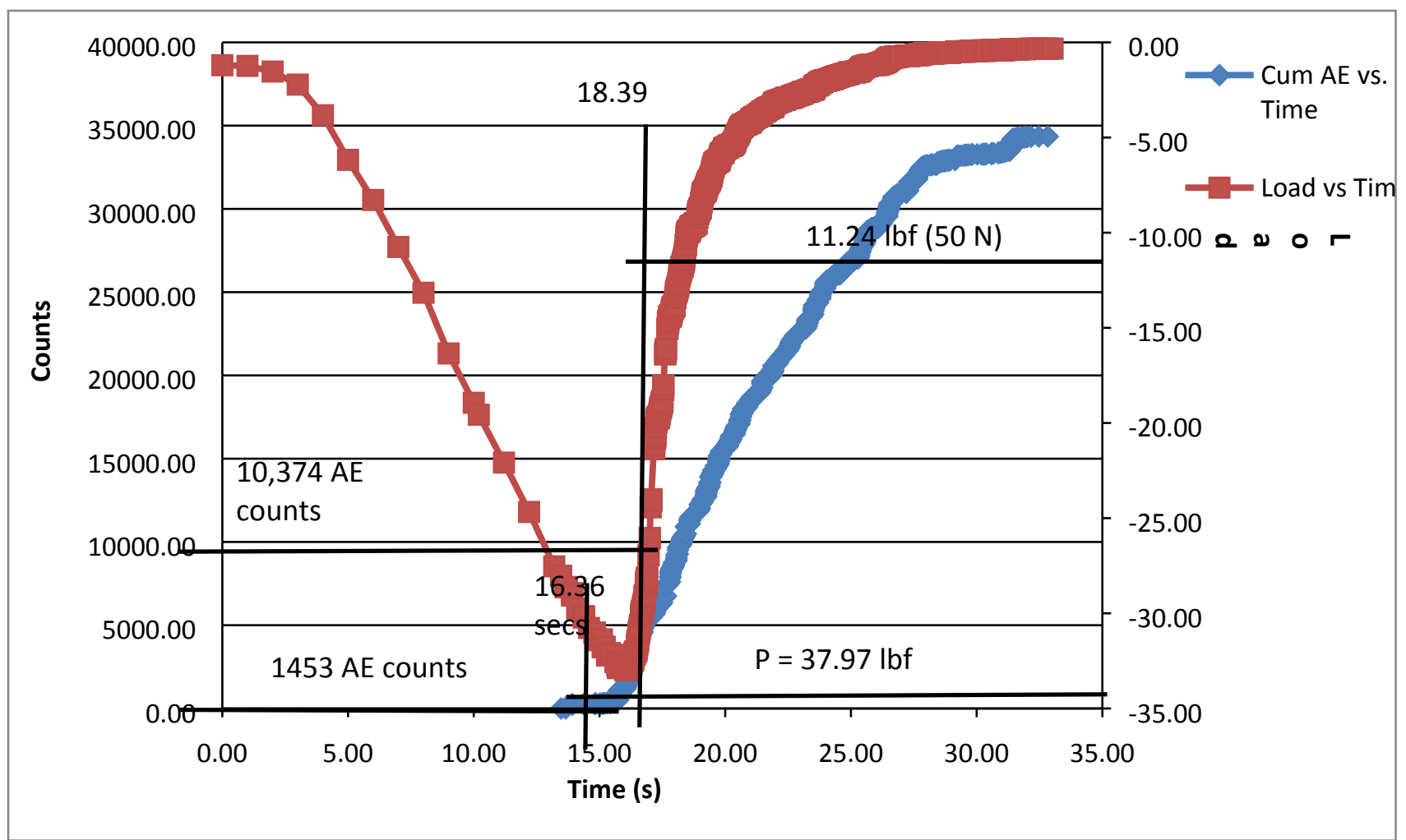

Figure 7 Load-time and cumulative AE counts-time curves for grade 2114 Block 2 specimen AG 23

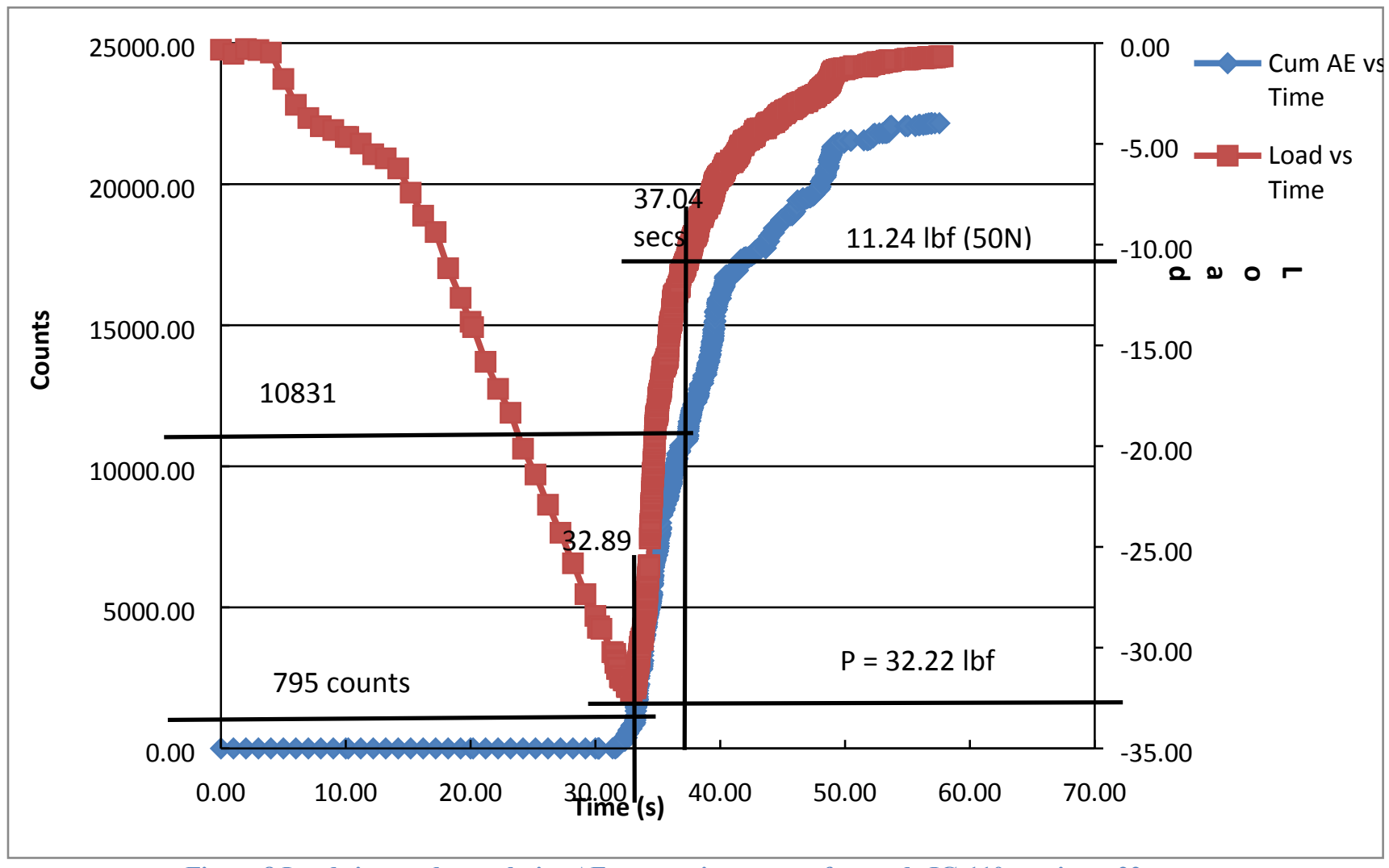

Figure 8 Load-time and cumulative AE counts-time curves for grade IG-110 specimen 22 


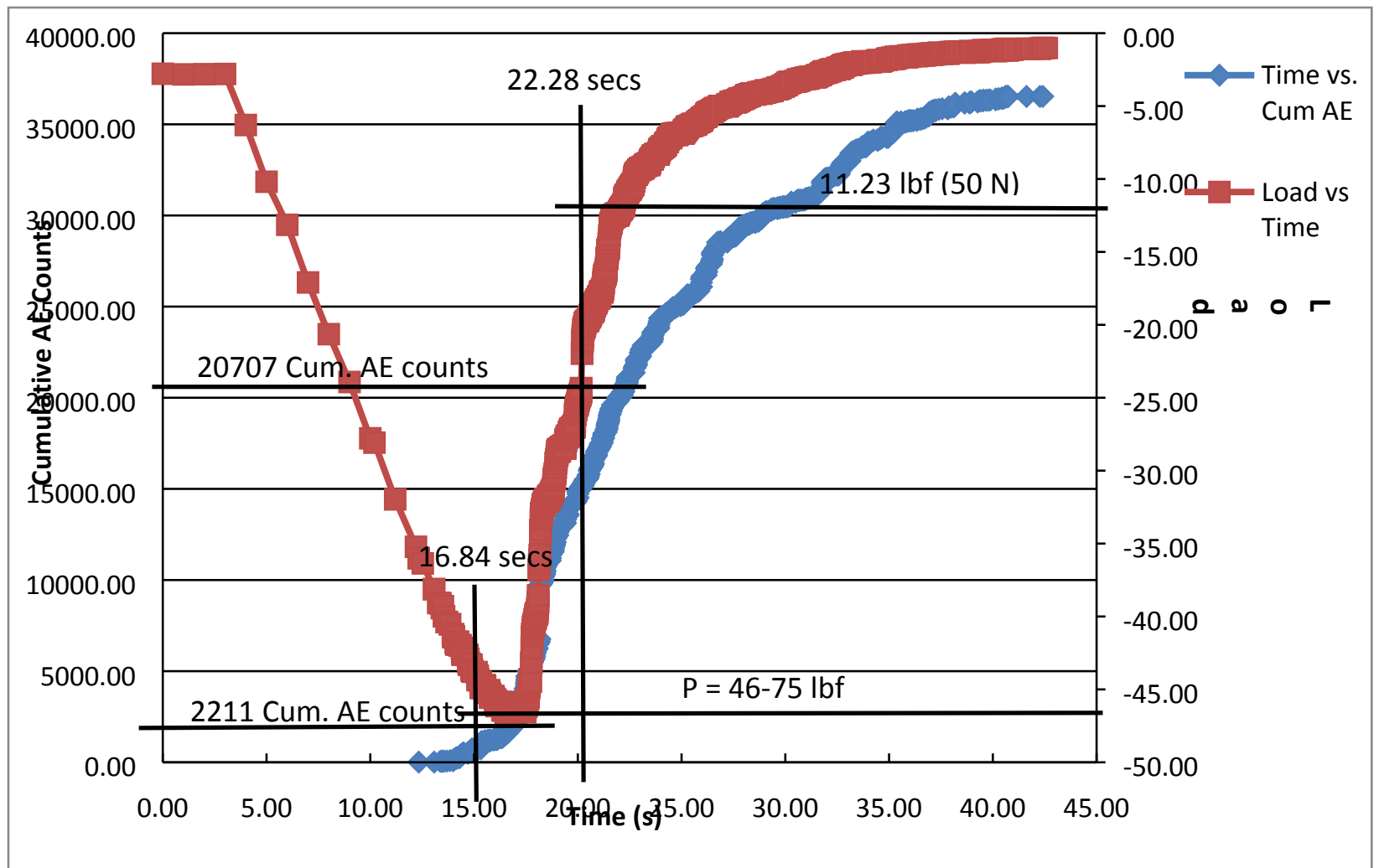

Figure 9 Load-time and cumulative AE counts-time curves for grade PCEA specimen WG K 118

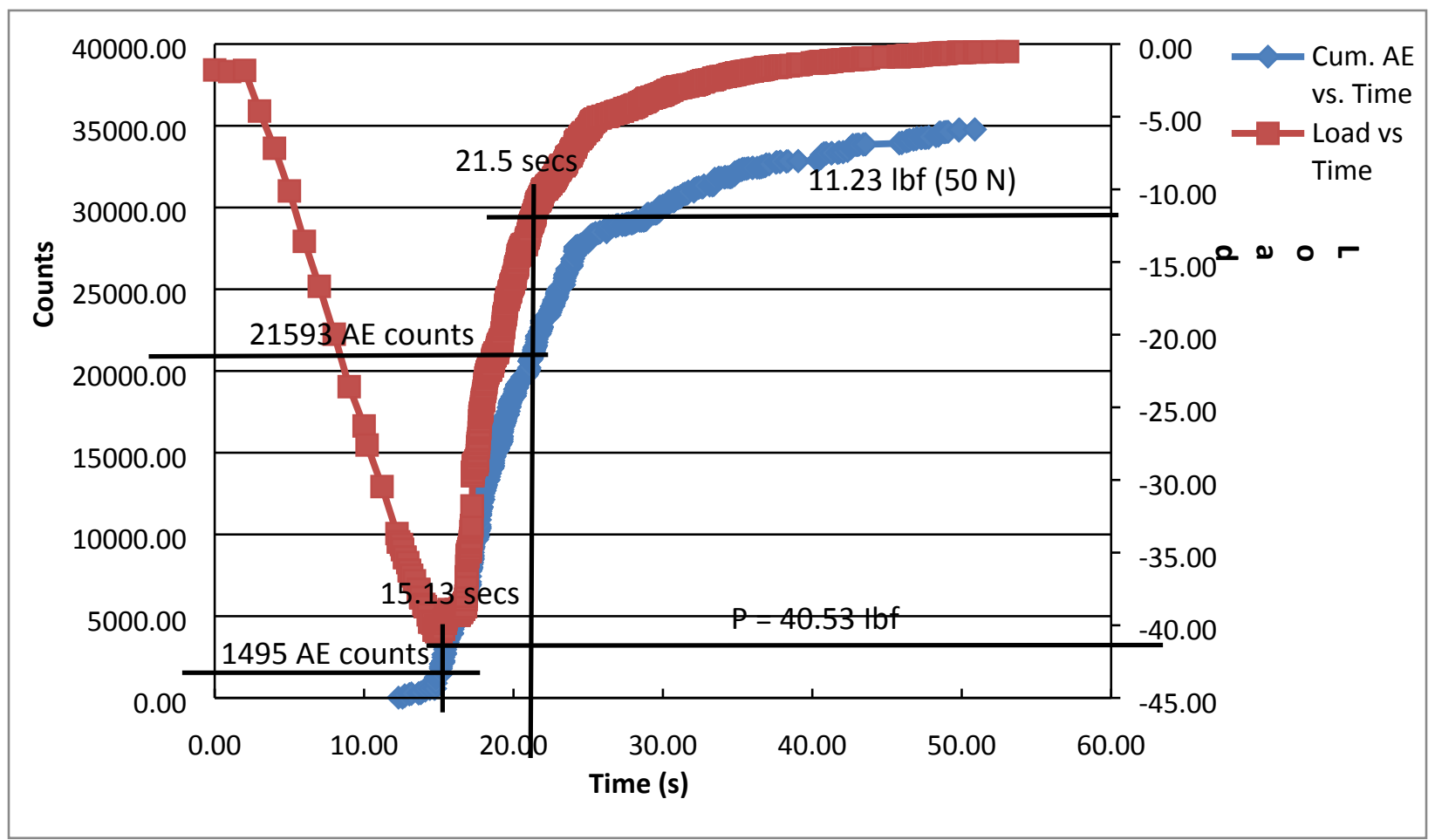

Figure 10 Load-time and cumulative AE counts-time curves for grade PCEA specimen AG KIc 75 


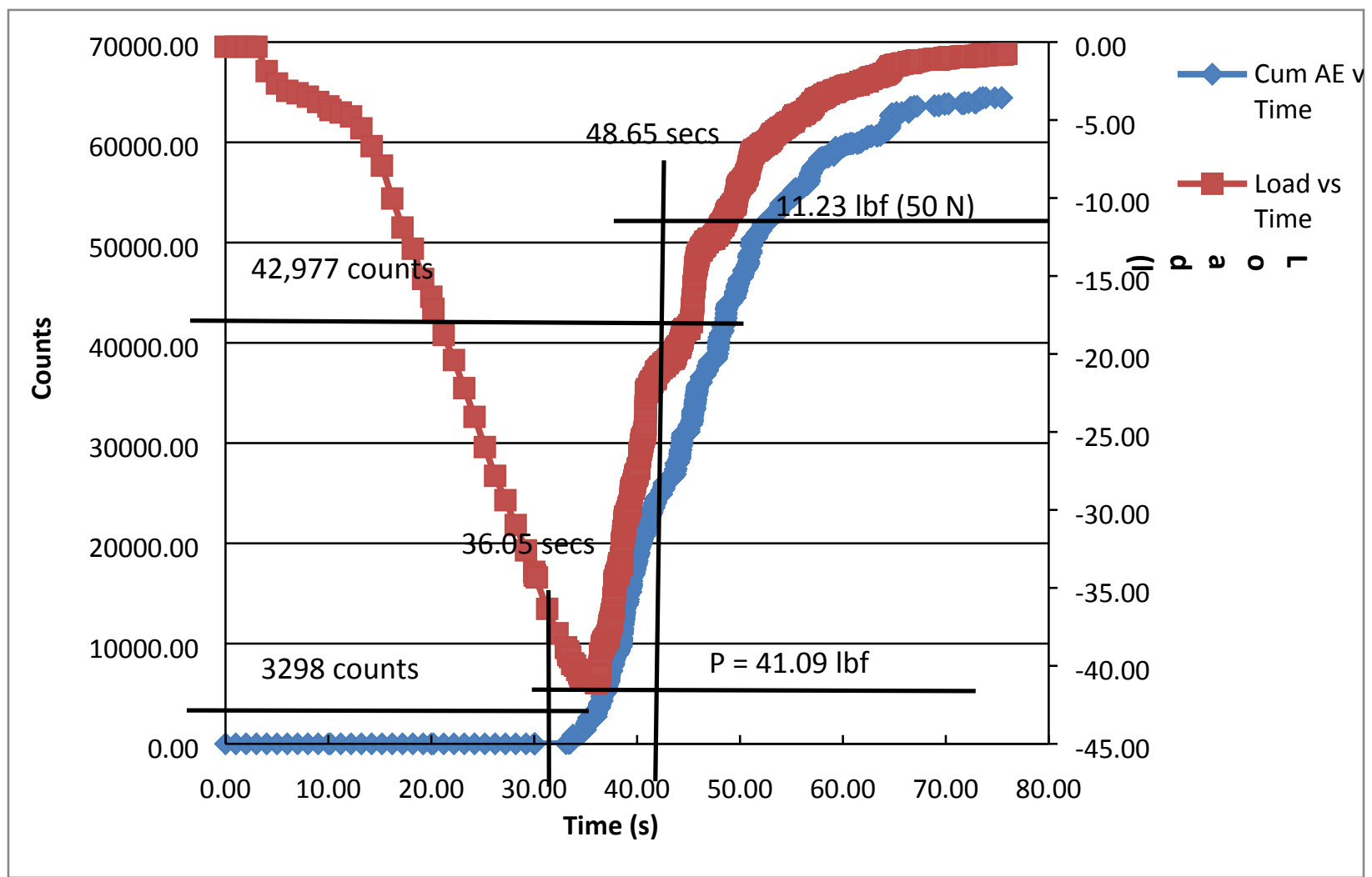

Figure 11 Load-time and cumulative AE counts-time curves for grade NBG-18 specimen 3B perp 10

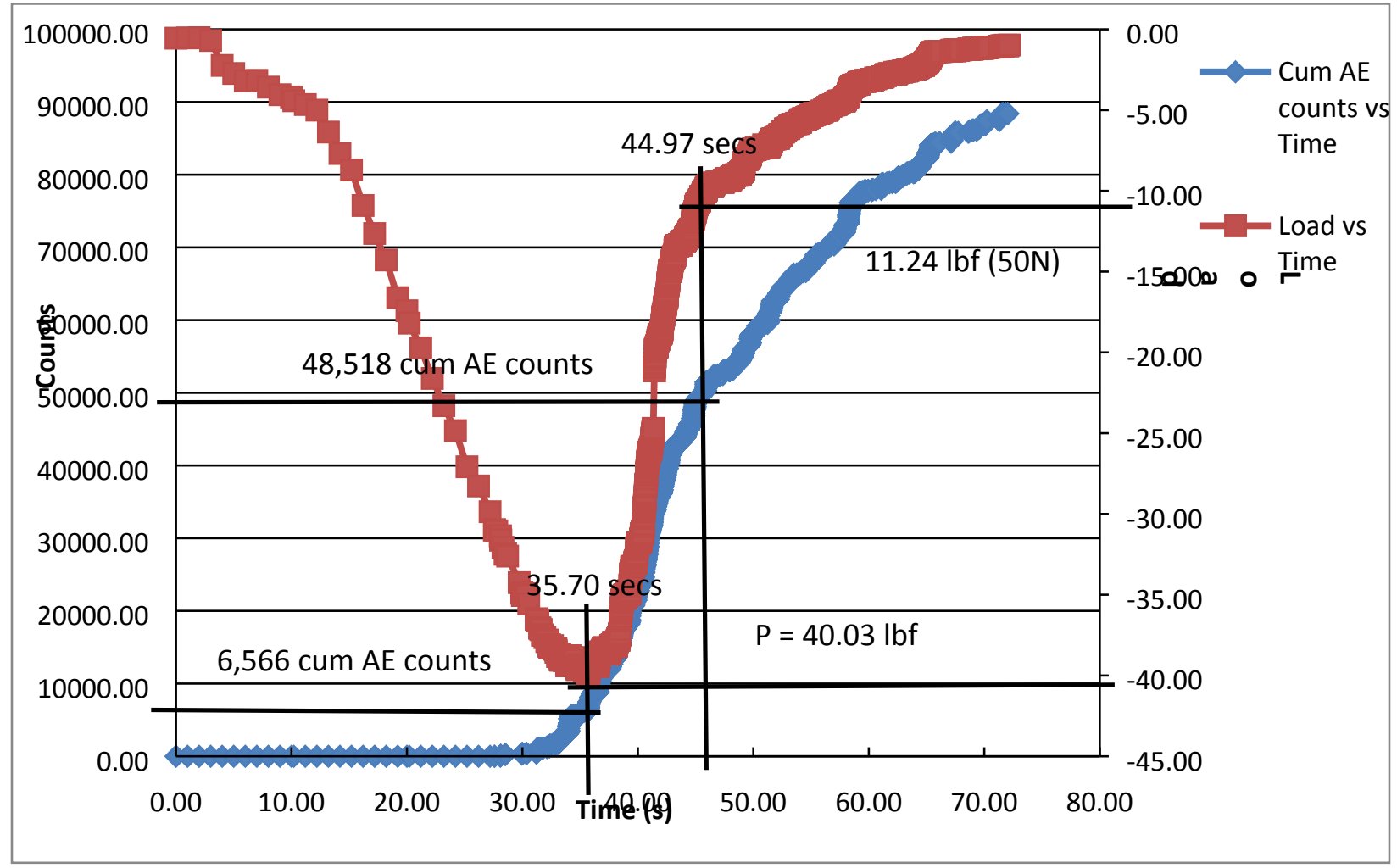

Figure 12 Load-time and cumulative AE counts-time curves for grade NBG-18 specimen 3B Par 15 


\subsection{DISCUSSION}

The summarized $\mathrm{K}_{\mathrm{Ic}}$ data from Table 3 are plotted against graphite texture (described by the manufacturers reported filler particle size) in Figure 13. Coarser textured graphite grades are seen to exhibit a larger $\mathrm{K}_{\mathrm{Ic}}$ value, i.e., the fine grain graphite grades tend to be more brittle. This trend is well established from previous studies in literature. In addition, the AE data shows that the coarser textured grades exhibit more acoustic emissions prior to sustaining their maximum load (Figure 14), or upon reaching their notional failure load of 50N (Figure 15). Anisotropy in $\mathrm{K}_{\mathrm{Ic}}$ was observed for grades PCEA and NBG-18. These were the medium grained graphite grades that were respectively extruded or vibrationally molded.

The fine grained, isostatically pressed grade MERCEN 2114 was isotropic with respect to $\mathrm{K}_{\mathrm{Ic}}$. Both the 2114(WG) and 2114(AG) returned a $\mathrm{K}_{\mathrm{Ic}}$ value of $1.15 \mathrm{MPa} \sqrt{\mathrm{m}}$. Although the standard deviation in the $2114(\mathrm{AG})$ specimens, (i.e., WG crack propagation orientation) was twice that of the standard deviation of the $2114(\mathrm{WG})$ specimens (i.e., AG crack propagation orientation). Given the direction of crack propagation in 2114 a more variable $\mathrm{K}_{\mathrm{Ic}}$ result from the $2114(\mathrm{WG})$ specimens might be expected. Graphite grade Toyo-Tanso IG-110 was assumed to be isotropic with respect to $\mathrm{K}_{\mathrm{Ic}}$.

Increasing $\mathrm{AE}$ with increasing $\mathrm{K}_{\mathrm{Ic}}$ is anticipated (Figure 16) since the "toughening" mechanisms in graphite, such as slip, shear, cleavage, and particularly micro-cracking, give rise to the acoustic emissions. ${ }^{10,11}$. Thus, coarser textured graphite grades, which exhibit more microcracking, are tougher than the fine textured graphite grades, even though they may well possess a lower strength than finer textured graphite.

The relationship between the cumulative AE and texture should be very apparent for sub-critical fracture events, i.e., those occurring prior to the graphite specimen sustaining its peak load, P. Indeed, inspection of Figure 14 shows a correlation coefficient better than 0.89 for the linear relationship between graphite filler particle size and cumulative AE. These data are replotted in Figure 17 with the filler particle size plotted on a logarithmic scale since the correlation apparently holds across four orders of magnitude in filler particle size. However, the filler particle size may not be the best descriptor of the graphite texture relevant to fracture toughness variations. 


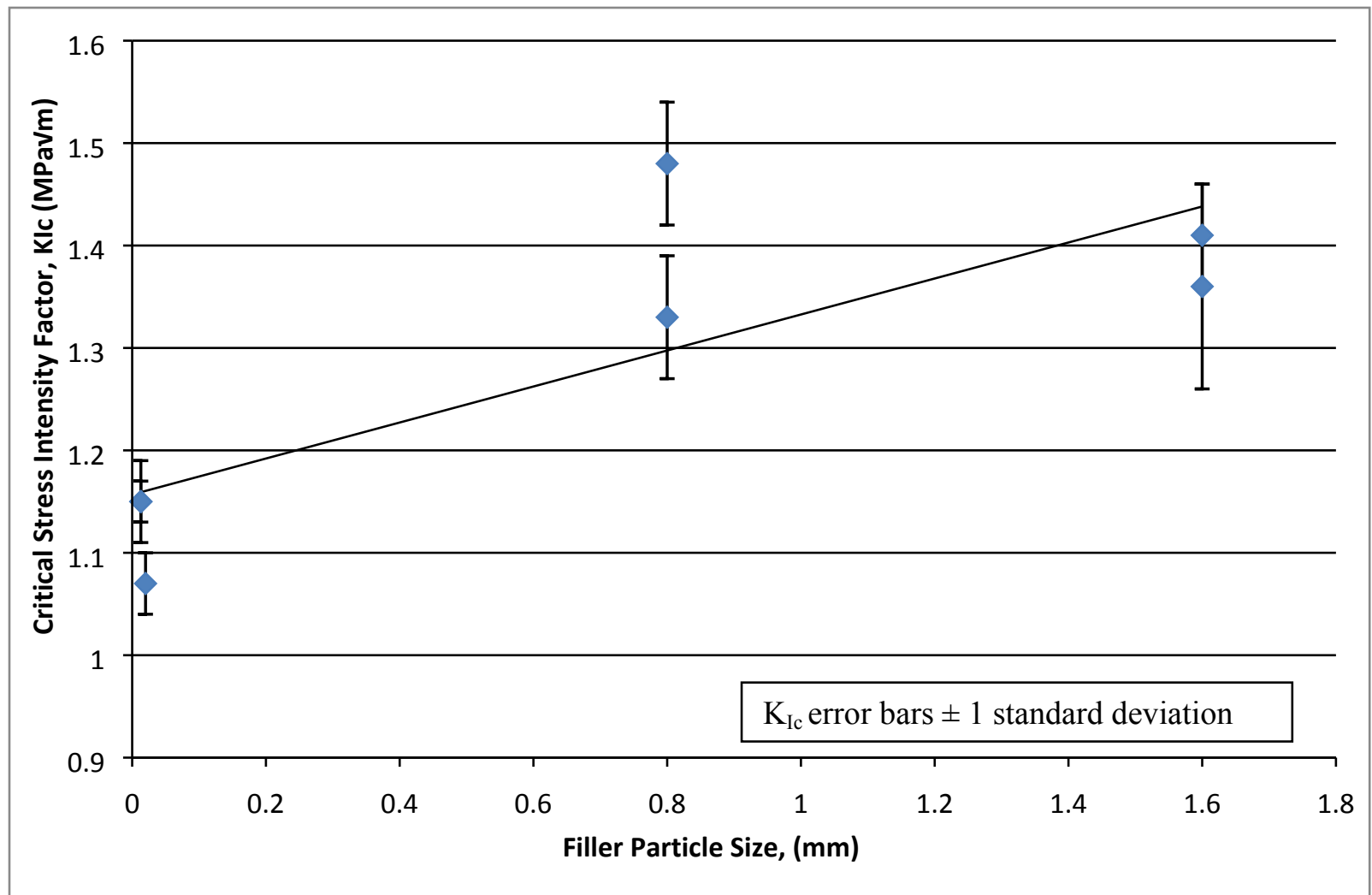

Figure 13 Variation of Critical Stress Intensity Factor with the graphite filler particle size

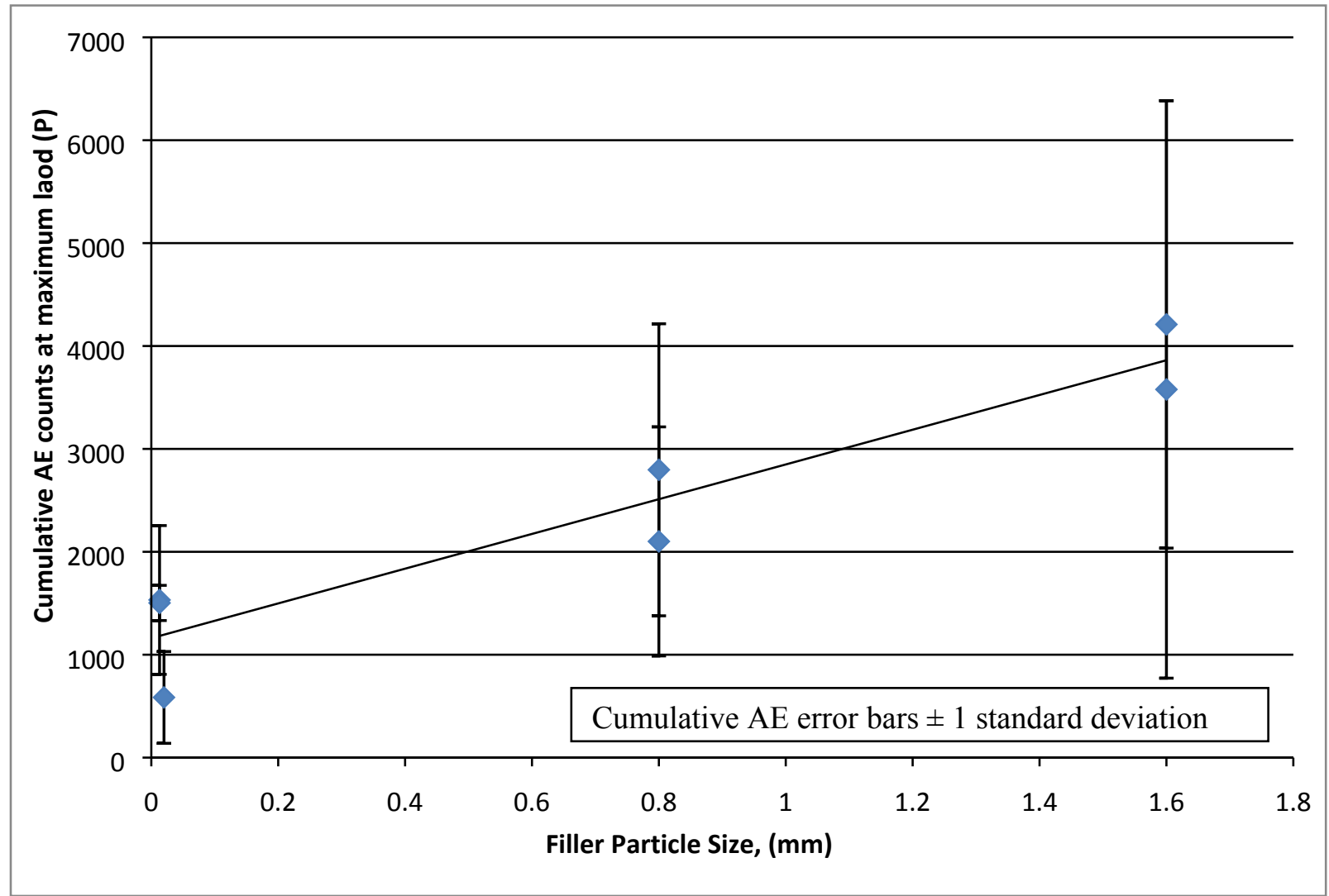

Figure 14 Variation of cumulative AE counts at maximum load, P, with the graphite filler particle size (mm) 


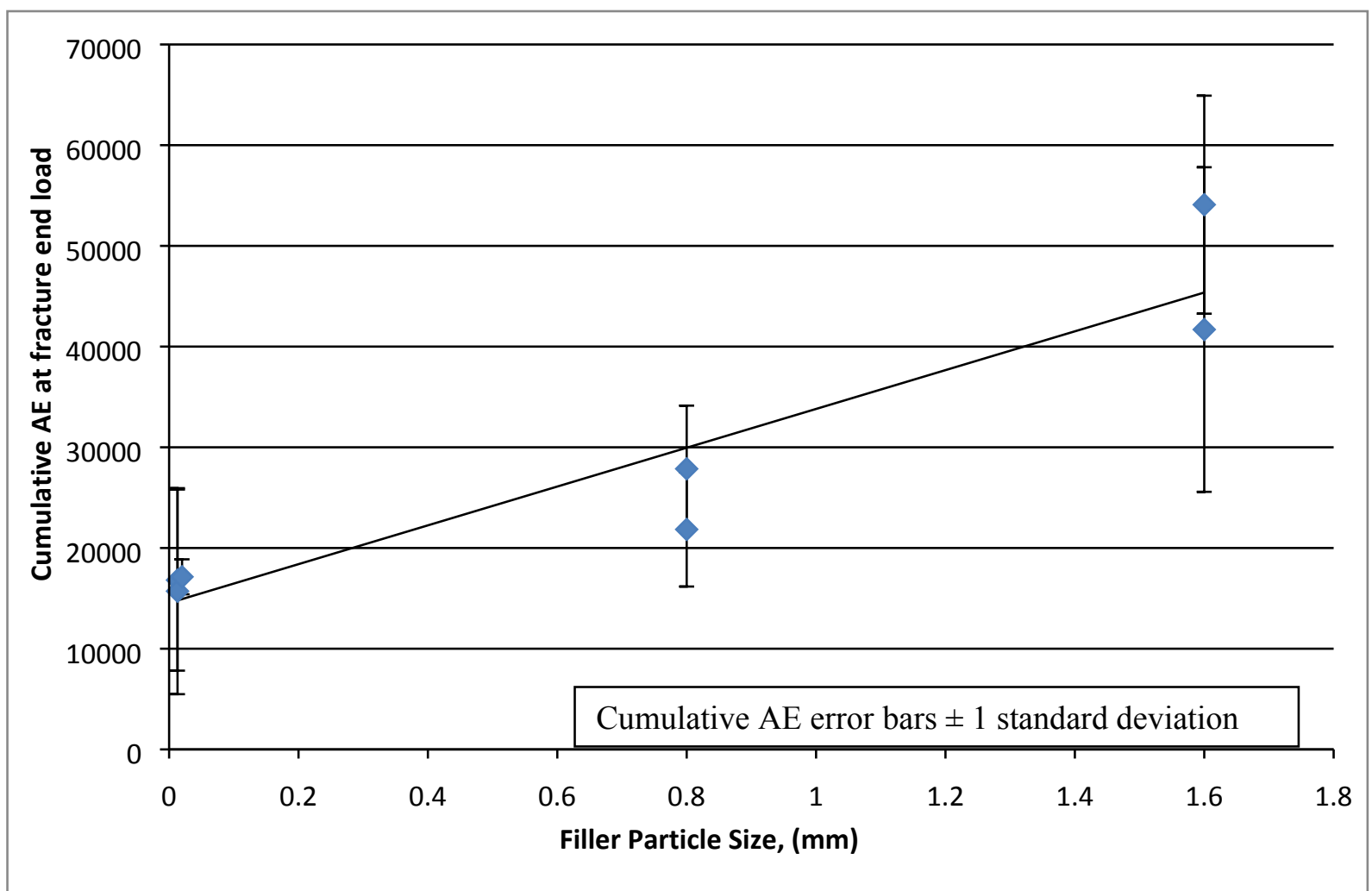

Figure 15 Variation of cumulative AE counts at fracture end load with the graphite filler particle size (mm) 


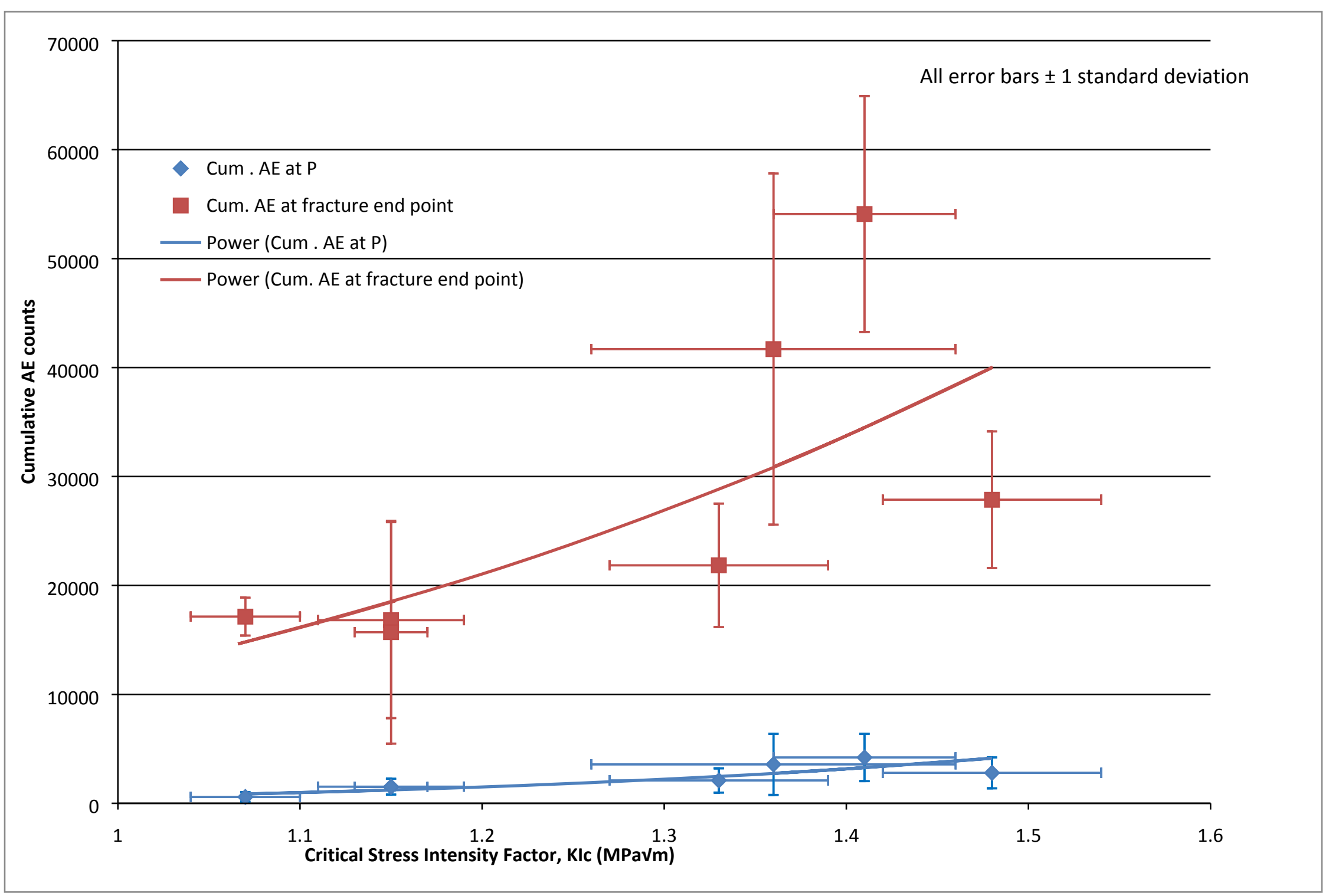

Figure 16 Variation of cumulative AE counts (i) at max load P, and (ii) at fracture end load with Critical Stress Intensity Factor 


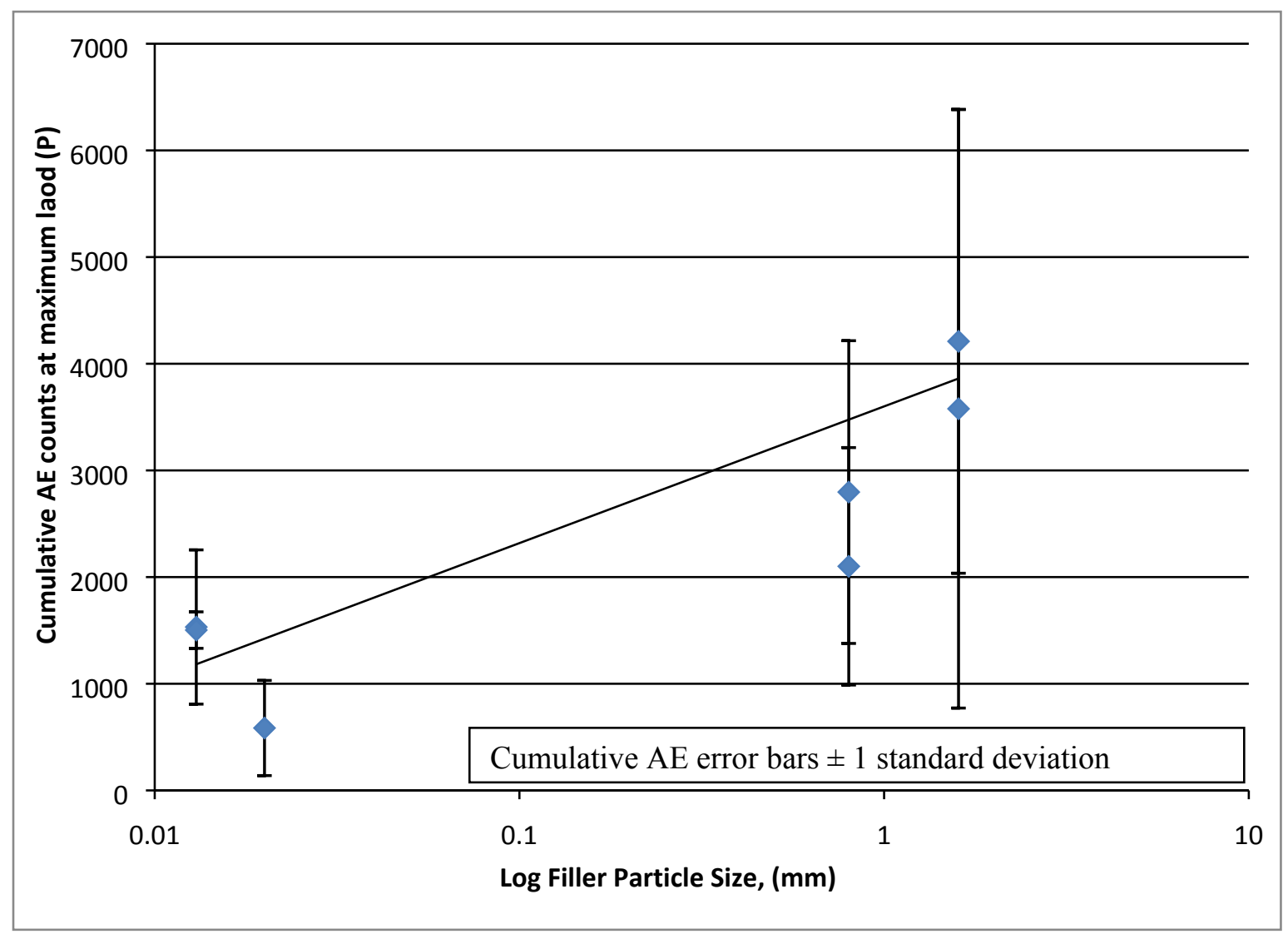

Figure 17 Variation of cumulative AE counts at maximum load, P, with the Log of graphite filler particle size (mm)

It is possible to define a volume of material in which the sub-critical, microcracking events of fracture occur i.e., those events giving rise to AE. The size of this "Process Zone"12" is defined by its radius, $r$, and is given as a function of the material's tensile strength and its critical stress intensity factor (tensile strength orthogonal to the fracture propagation direction).

$$
\text { Process Zone Size }, \quad r_{c}=\frac{1}{2 \pi}\left[\frac{K_{I c}}{\sigma_{t}}\right]^{2}
$$

Where $\mathrm{K}_{\mathrm{Ic}}$ is the critical stress intensity factor $(\mathrm{MPa} \sqrt{\mathrm{m}})$ and $\sigma_{t}$ is the tensile strength $(\mathrm{MPa})$.

Thus, graphite grades with smaller $\mathrm{K}_{\mathrm{Ic}}$ and higher tensile strength (such as fine-grained graphite grades) would exhibit smaller process zone size. The "process zone" sizes for the six graphite grade/orientation combinations reported in this study are given in Table 3. As the texture coarsens the process zone increases (Table 3). However, the increase of Process Zone size is from $\mathrm{r}=1.7 \mathrm{~mm}$ to $13.4 \mathrm{~mm}$, i.e., approximately one order of magnitude compared to four orders of magnitude when describing the texture with the filler particle size. The variation of $\mathrm{K}_{\mathrm{Ic}}$ with the Process Zone size is shown in Figure 18. 


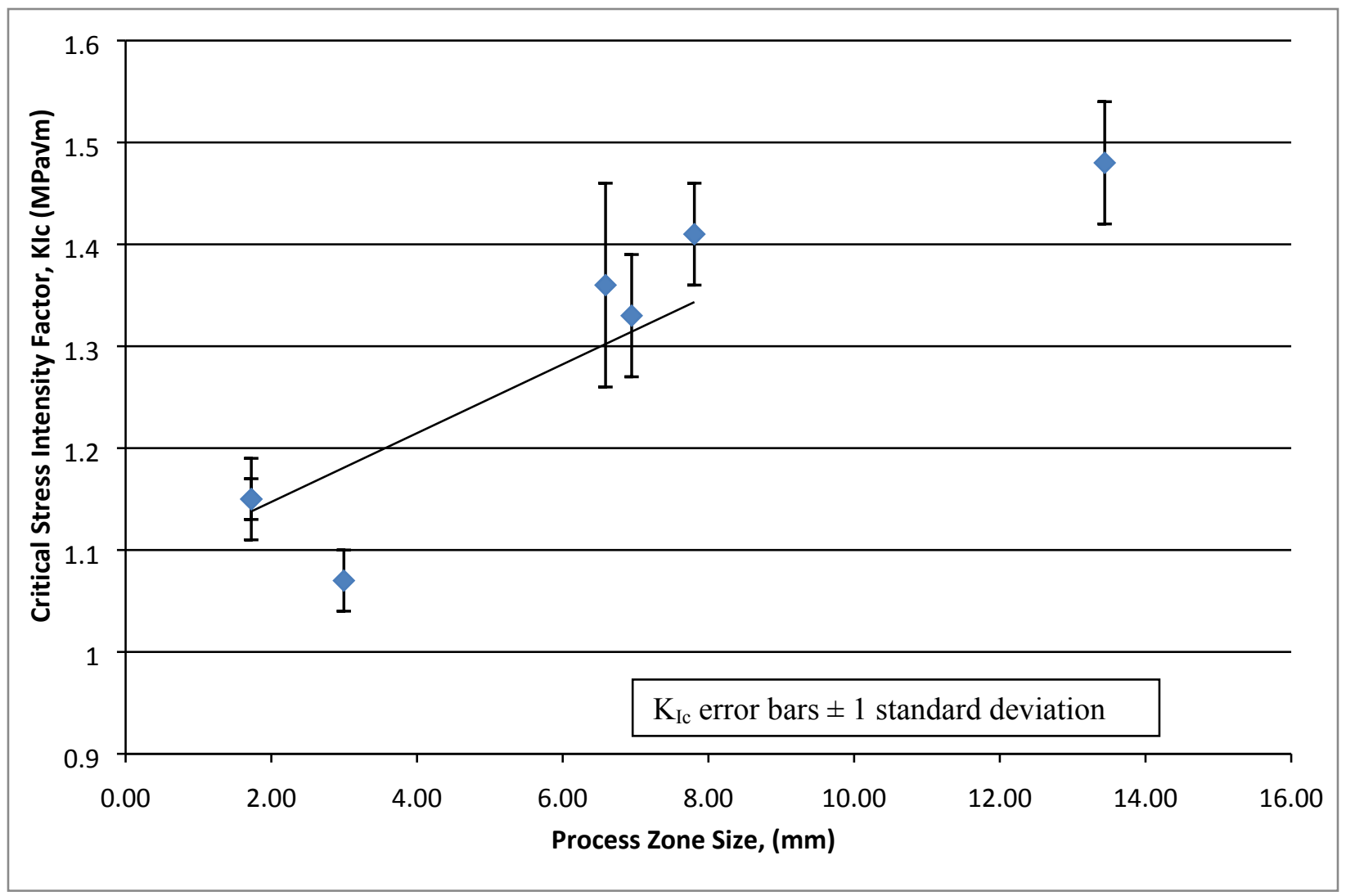

Figure 18 Variation of Critical Stress Intensity Factor with the graphite fracture process zone size

As expected, the correlation between $\mathrm{K}_{\mathrm{Ic}}$ and texture (i.e., $\mathrm{PZ}$ ) is improved with a linear fit to the data from Table 3 (Figure 18). The data suggests that $\mathrm{PZ}$ is a more useful description of the graphite texture (than is filler particle size) when trying to define the structure for the purpose of analysis or test. Later, in section 4, General Discussion, it will be shown how the PZ can be used to define the finite element mesh cell volume as prescribed by the American Society of Mechanical Engineers (ASME) design code. 


\section{SHEAR STRESS INTENSITY FACTOR, $\mathrm{K}_{\text {IIc }}$}

\subsection{EXPERIMENTAL}

The experimental method used to test the Double Edge Notch Compression (DENC) specimens was the same as that used in our previous testing ${ }^{13,14}$ of identical geometry DENC specimens.

\subsection{RESULTS}

The additional $\mathrm{K}_{\mathrm{IIc}}$ testing reported here was of graphite grades PCEA (both orientations) and IG-110, which was assumed to be isotropic with respect to $\mathrm{K}_{\text {IIc }}$. The results of the new measurements are reported in Table 14, Table 15 and Table 16 (see Appendix A, Experimental Data),

The $\mathrm{K}_{\text {IIc }}$ data means from this work are summarized in This ratio is clearly greater than 1.0 for all graphite grades examined here.

Table 4, along with prior data for NBG-18(WG) specimens. Also reported are the ratio values of $\mathrm{K}_{\mathrm{IIc}} / \mathrm{K}_{\mathrm{Ic}}$ for the grade/orientations were we have both $\mathrm{K}_{\mathrm{Ic}}$ and $\mathrm{K}_{\mathrm{IIc}}$ values (PCEA (PAR), PCEA (PER), NBG-18 (WG) and IG-110). This ratio is clearly greater than 1.0 for all graphite grades examined here.

Table 4 Summary $K_{I c}$ and $K_{I I c}$ data for the specimens tested here (note, in the case of the PCEA (PAR) specimens and the NBG-18 (WG) specimens our prior data is included or reported ${ }^{13,14}$ )

\begin{tabular}{|c|c|c|c|c|c|}
\hline \multirow{2}{*}{$\begin{array}{l}\mathrm{K}_{\text {IIC Graphite }} \text { specimen } \\
\text { and Notch } \\
\text { Orientation }\end{array}$} & \multicolumn{2}{|c|}{$K_{\mathrm{Ic}}$} & \multicolumn{2}{|c|}{$K_{\| c}$} & \multirow{2}{*}{ RATIO $K_{I I d} / K_{I c}$} \\
\hline & MPaVm & $\mathrm{n}\left(\mathrm{K}_{\mathrm{Ic}}\right)$ & MPaVm & $\mathrm{n}\left(\mathrm{K}_{\mathrm{IIC}}\right)$ & \\
\hline $\begin{array}{c}\text { PCEA (PAR } \\
\text { SPEC)(AG } \\
\text { notch) }\end{array}$ & $\begin{array}{c}1.48 \pm \\
0.06\end{array}$ & 57 & $\begin{array}{l}2.41 \pm \\
0.28^{*}\end{array}$ & $\begin{array}{c}57[8 \text { in } \\
2015) \\
\end{array}$ & 1.63 \\
\hline $\begin{array}{c}\text { PCEA (PERP } \\
\text { SPEC)(WG } \\
\text { notch) }\end{array}$ & $1.33 \pm 0.06$ & 24 & $\begin{array}{c}2.21 \pm \\
0.19\end{array}$ & 24 & 1.66 \\
\hline NBG-18 (AG) & $1.41 \pm 0.05$ & 25 & & & \\
\hline $\begin{array}{c}\text { NBG-18 } \\
\text { (WG) }\end{array}$ & $1.36 \pm 0.1$ & 25 & $\begin{array}{c}2.2 \pm \\
0.53^{* *}\end{array}$ & $\begin{array}{c}10 \text { [from } \\
2015 \\
\text { testing] }\end{array}$ & 1.62 \\
\hline IG-110 & $\begin{array}{c}1.07 \pm \\
0.03 \\
\end{array}$ & 32 & $\begin{array}{c}2.87 \pm \\
0.14\end{array}$ & 26 & 2.68 \\
\hline
\end{tabular}

*includes the additional specimens ( type 4's) tested in 2015 [see Carbon 98 (2016) 267-279]

**from type 4 specimens tested in 2015 [see Carbon 98 (2016) 267-279] 


\subsection{DISCUSSION}

The prior PCEA (PAR) $\mathrm{K}_{\mathrm{IIc}}$ value was $2.26 \pm 0.37 \mathrm{MPa} \sqrt{\mathrm{m}}$, and the new data for PCEA (PAR) is reported as $\mathrm{K}_{\text {IIc }}=2.44 \pm 0.26$ (with PCEA (PER) $\mathrm{K}_{\text {IIc }}=2.21 \pm 0.19$ ). The $\mathrm{K}_{\text {IIc }}$ values obtained here for PCEA (PAR) and PCEA (PER) are in good agreement with the values obtain previously for PCEA (PAR). Interestingly, the $\mathrm{K}_{\text {IIc }}$ value obtained for the isostatically pressed, fine grain graphite, IG-110 was substantially larger than that measured for the medium grained PCEA or NBG-18 graphite grades (2.87 \pm 0.14 for IG-110 cf. $\left.2.2-2.4 \mathrm{~K}_{\mathrm{IIc}}\right)$ suggesting that IG-110 is more shear resistant than the medium grain graphite grades PCEA or NBG-18.

Previously, Shetty ${ }^{15}$ had speculated that $\mathrm{K}_{\mathrm{IIc}}$ was not a unique materials property, i.e., there is a different value of $\mathrm{K}_{\mathrm{IIc}}$ and hence a different Shetty coefficient, c, for each specimen geometry and loading condition. Moreover, from the results of the current study it appears the $\mathrm{K}_{\text {IIc }}$ values derived from the DENC geometry specimens may not be conservative and are seen to be artificially high. With these negative results for $\mathrm{K}_{\mathrm{IIc}}$ testing on other graphite grades, we have not tested the grade 2114 graphite for its shear toughness and will not pursue this line of research further. 


\section{GENERAL DISCUSSION}

\subsection{APPLICATION OF FRACTURE MECHNICS IN ASTM STANDARDS AND SPECIFICATIONS}

ASTM Standards specifications for nuclear graphite ${ }^{4,5}$ do not currently require a minimum Critical Stress Intensity Factor $\left(\mathrm{K}_{\mathrm{Ic}}\right)$ value. The specified minimum value was removed during the past balloting process because there was no accepted standard test method available to determine a viable $\mathrm{K}_{\mathrm{Ic}}$ value for graphite. An approved standard test method ${ }^{3}$ now exists and is used to report the results in this comprehensive study with a fixed specimen size. Thus, we may confidently specify a minimum $\mathrm{K}_{\mathrm{Ic}}$ and ASTM test method to the nuclear graphite ASTM Standard specifications (D7219 and D7301).

Table 5 gives the mean value minus three standard deviations (mean $-3 *$ St. Dev.) for the seven graphite grade/orientation combinations studied here. If the value of the lowest reported mean $3 *$ St. Dev. are taken from Table 5 a value of 0.98 would be obtained for the minimum $\mathrm{K}_{\mathrm{Ic}}$. For ASTM standard specification purposes a minimum $\mathrm{K}_{\mathrm{Ic}}$ of $0.95 \mathrm{MPa} \sqrt{\mathrm{m}}$ (determined on a $200 \mathrm{x}$ $20 \times 15-\mathrm{mm}$ SENB) should be required for any graphite grade considered for nuclear component applications. At this level, none of the grades in Table 5 (or other current grades being considered for nuclear applications such as Sino-Steel's grade SNG742 ${ }^{8}$ ) would be excluded.

Table 5 Mean values, Standard deviation and [mean-(3*St. Dev.)] values

\begin{tabular}{|l|c|c|c|}
\hline \multirow{2}{*}{\multicolumn{1}{|c|}{ Grade }} & \multicolumn{3}{|c|}{$\mathrm{K}_{\mathrm{Ic}}(\mathrm{MPa} \sqrt{\mathrm{m}})$} \\
\cline { 2 - 4 } & mean & st dev & mean-3 st. dev. \\
\hline $2114(\mathrm{WG})$ & 1.15 & 0.04 & 1.03 \\
\hline $2114(\mathrm{AG})$ & 1.15 & 0.02 & 1.09 \\
\hline IG-110 & 1.07 & 0.03 & 0.98 \\
\hline PCEA (WG) & 1.33 & 0.06 & 1.15 \\
\hline PCEA (AG) & 1.48 & 0.06 & 1.3 \\
\hline NBG-18 (WG) & 1.36 & 0.1 & 1.06 \\
\hline NBG-18 (AG) & 1.41 & 0.05 & 1.26 \\
\hline
\end{tabular}

Revisions to ASTM Standard Specifications D7219 and D7301 shall be introduced at the ASTM DO2.F Committee on Manufactured Carbons and Graphite.

\subsection{APPLICATION IN ASME GRAPHITE CORE DESIGN CODE}

The ASME B\&PV Code (2013 edition) in Section III, Division 5, sub-part A: Graphite materials, Article 3: Design, requires in paragraph HHA-3217 the calculation of the probability of component failure. This calculation is achieved through the application of a Finite Element Model (FEM) stress analysis to assess the stresses in a graphite core component. The code defines the FEM integration volume with two conditions (see HHA 3000). 
Condition 1: group volume $\mathrm{V}_{\mathrm{I}, \mathrm{II}, \mathrm{III}}, \ldots>\mathrm{V}_{\mathrm{m}}$

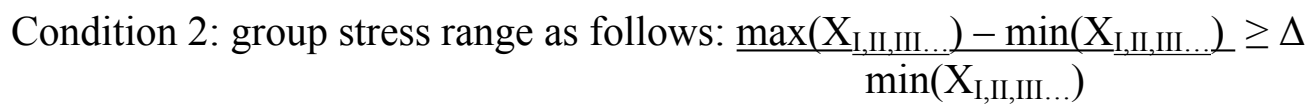

Where,

$\mathrm{Vm}=$ a process zone volume, which is the volume described by the cube of 10 times the maximum grain size, and

$\Delta=$ the stress range parameter, $7 \%$.

The integration volume defines the integration points at which, using the FEM analysis and the equations given in the ASME B\&PV code (sub part A: Graphite, Article HHA 3000 Design), an equivalent stress is defined and compared to the materials strength. Thus, the probability of survival is calculated.

For medium grained nuclear graphite such as NBG-18, with a maximum grain size of $1.6 \mathrm{~mm}$, $\mathrm{V}_{\mathrm{m}}$ is $(10 \times 1.6)^{3}=(16 \mathrm{~mm})^{3}$ or a volume or $4096 \mathrm{~mm}^{3}$. For a fine grained graphite such as IG110 , with a grain size of $20 \mu \mathrm{m}$, the integration volume $\mathrm{V}_{\mathrm{m}}=(10 \times 20)^{3}=(200 \mu \mathrm{m})^{3}$ or a volume of $0.008 \mathrm{~mm}^{3}$, a variation in $\mathrm{V}_{\mathrm{m}}$ of some 6 orders of magnitude!

Unfortunately, this ASME methodology places a huge computational analysis (and financial) burden on the designer of a fine grain graphite core component or assembly. Moreover, as is shown in Figure 19 this methodology places unrealistic constraints on the use of a fine grained graphite because the computed probabilities of failure are extremely conservative, if not untenable. 


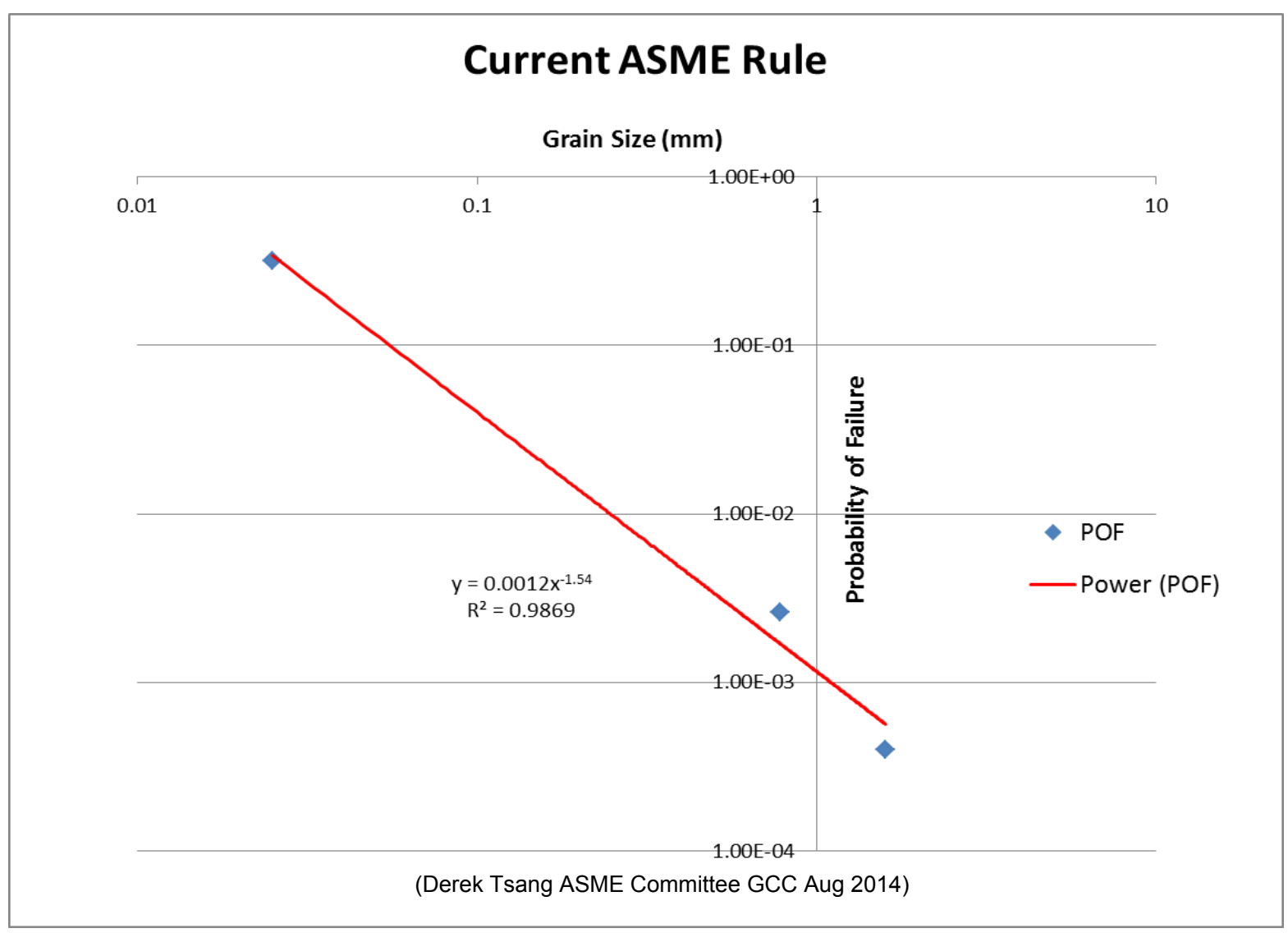

Figure 19 Calculated probability of failure for nuclear graphite core components as a function of Grain Size, mm.

The actual integration volume, $\mathrm{V}_{\mathrm{m}}$, used in the stress analysis should depend upon several factors, such as:

- Graphite texture (grain size is not a good indicator of texture).

- Component geometry (i.e., section size, web thickness, component size)

- Anticipated stress or stress gradient

The designer must have some discretion when determining the integration volume. What we describe here is suggested guidance on the initial selection of the integration volume.

Essentially, the integration volume is a kind of process zone, and as such, should be equated with the fracture process zone given by equation 3, previously. As discussed above, the fracture process zone is a better descriptor of graphite texture than is the grain or filler particle size when describing fracture as a function of texture. Calculated values of the fracture Process Zone Radius and volume are given in Table 3 for the graphite grades in the current study. From the critical radius ( $\mathrm{PZ}$ size) the appropriate integration volume, $\mathrm{V}_{\mathrm{m}}$, has been calculated and is given in Table 6. 


Table 6 Existing and Proposed new $\mathrm{V}_{\mathrm{m}}$ for the ASME Sect III, Div. 5 Graphite code (HH
\begin{tabular}{|c|c|c|c|c|}
\hline & \multicolumn{2}{|c|}{ Existing ASME Rule } & \multicolumn{2}{|c|}{ Proposed New Rule } \\
\cline { 2 - 5 } & Grain size & $\mathrm{V}_{\mathrm{m}}$ & $\begin{array}{c}\text { PZ size, } \mathrm{r}_{\mathrm{c}} \\
(\mathrm{mm})\end{array}$ & Proposed $\mathrm{V}_{\mathrm{m}}$ \\
\cline { 2 - 5 } GRADE & $\mathrm{Mm}$ & $\mathrm{mm}^{3}$ & $\mathrm{~mm}$ & $\begin{array}{c}4 / 3(\mathrm{Pi}) \mathrm{r}_{\mathrm{c}}{ }^{3} \\
\mathrm{~mm}^{3}\end{array}$ \\
\hline $\begin{array}{c}\text { NBG-18 } \\
\text { (WG) }\end{array}$ & 1.6 & 4096 & 6.6 & 1198.8 \\
\hline $\begin{array}{c}\text { NBG-18 } \\
\text { (AG) }\end{array}$ & 1.6 & 4096 & 7.8 & 1995.5 \\
\hline PCEA (WG) & 0.8 & 512 & 10.8 & 5335.5 \\
\hline PCEA (AG) & 0.8 & 512 & 8.6 & 2664.3 \\
\hline IG-110 & 0.02 & 0.008 & 3.0 & 113.1 \\
\hline 2114 & 0.013 & 0.0022 & 1.7 & 21.7 \\
\hline
\end{tabular}

The proposed new integration volume, $\mathrm{V}_{\mathrm{m}}$, varies by only $\sim \mathrm{x} 10$ between IG-110 to NBG-18, rather than the $\sim \mathrm{x} 1000000$ variation of the existing ASME definition of $\mathrm{V}_{\mathrm{m}}$. An ASME code action has been initiated in response to a formal enquiry from SINAP, Shanghai, China to try to eliminate the conservatism bought about by linking $\mathrm{V}_{\mathrm{m}}$ to the graphite grain size. The ASME graphite committee expects to conduct a series of benchmarks using set verification problems to determine (i) the validity of this approach to estimating the FEM integration volume, and (ii) the appropriate value of $\Delta$, the stress range parameter for this approach.

\section{CONCLUSIONS}

Here we have reported the $\mathrm{K}_{\mathrm{Ic}}$ and $\mathrm{K}_{\mathrm{IIc}}$ values for several nuclear graphite grades of interest to the USDOE Advanced Reactor Technologies program. The determination of $\mathrm{K}_{\text {IIc }}$ from the Double Edge Notched Compression (DENC) specimen was successful, our new data agreeing well with our previously reported data. However, the realization that $\mathrm{K}_{\text {IIc }}$ may not be a material constant means we will not pursue this line of research further. $\mathrm{K}_{\mathrm{Ic}}$ data was generated for four grades (both orientations for three grades) ranging from the fine grain isostatic pressed grades (IG-110 and 2114) to the medium grained vibrationally molded NBG-18 and the extruded medium grained PCEA. The acquisition of these data has allowed a minimum value for nuclear graphite $\mathrm{K}_{\mathrm{Ic}}$ to be identified $\left(\mathrm{K}_{\mathrm{Ic}(\min )}=0.95 \mathrm{MPa} \sqrt{\mathrm{m}}\right)$. This value and the $\mathrm{K}_{\mathrm{Ic}}$ ASTM test standard (with an appropriate note about the recommended specimen size) will be added to the ASTM specifications for Nuclear Graphite.

Acoustic Emission was monitored during fracture and is thought to be related to activity stemming from fracture activities in the fracture process zone. Both the cumulative acoustic emission counts and the measured $\mathrm{K}_{\mathrm{Ic}}$ increase with increasing fracture process zone critical radius and increasing grain size. However, the correlation is much better for the $\mathrm{K}_{\mathrm{Ic}}$ vs process zone radius than for the $\mathrm{K}_{\mathrm{Ic}}$ vs grain size, suggesting that fracture mechanics derived process zone size is a better indicator of graphite texture than is the widely used grain size. 
The ASME design Code for graphite cores uses a probabilistic approach in which the stress from a FEM analysis is compared to a known strength distribution for the selected graphite. The code rules specify how the FEM integration volume should be calculated based upon the graphite grain size. This methodology has been shown to penalize the use of fine grain graphite. A code action has been initiated to link the FEM cell size (Integration volume) to the fracture process zone size (derived from the $\mathrm{K}_{\mathrm{Ic}}$ and $\sigma_{\mathrm{t}}$ ). Note that $\sigma_{\mathrm{t}}$ is currently obtained from ASTM C565 ${ }^{16}$ or ASTM C749 ${ }^{17}$ dog-bone type specimens whose size does not always lend itself to testing irradiated graphite. Consequently, the DO2.F Committee on Manufactured Carbons and Graphite is pursuing a standard for the Brazilian Disc specimen (Split-disk specimen) for $\sigma_{t}$ whose geometry does lends itself to smaller and irradiated samples.

\section{ACKNOWLEDGEMENTS}

This work is sponsored by the U.S. Department of Energy, Office of Nuclear Energy Science and Technology, Advanced Reactor Technologies, under contract DE-AC05-00OR22725 with Oak Ridge National Laboratory, managed by UT-Battelle, LLC.

\section{DISTRIBUTION}

ORNL

Tim Burchell

Don Erdmann III

James Hunter

Cara Hannel

Rick R. Lowden
$\underline{\mathrm{INL}}$

Michael Davenport

William Windes 
APPENDIX A EXPERIMENTAL DATA 
Table $7 \mathrm{~K}_{\mathrm{Ic}}$ and $\mathrm{AE}$ data for grade 2114, WG specimen (AG fracture orientation)

\begin{tabular}{|c|c|c|c|c|c|c|c|c|c|c|c|c|c|c|}
\hline \multicolumn{15}{|c|}{$2114(15 \times 20 \times 200 \mathrm{~mm}, \mathrm{a} / \mathrm{W}=0.40)$} \\
\hline \multirow[t]{2}{*}{ Specimen ID } & \multirow{2}{*}{$\begin{array}{c}\text { Spec } \\
\text { Orien } \\
\text { tatio } \\
n\end{array}$} & \multirow{2}{*}{$\begin{array}{c}\text { Crac } \\
\text { k } \\
\text { Orie } \\
\text { ntati } \\
\text { on }\end{array}$} & \multirow[t]{2}{*}{$\mathrm{g}$} & \multicolumn{2}{|c|}{$P(\max )$} & \multirow{2}{*}{$\begin{array}{l}\mathrm{S} \\
\\
\\
\mathrm{M}\end{array}$} & \multirow{2}{*}{$\begin{array}{c}B^{*}\left(W^{\wedge}(3 / 2\right. \\
))\end{array}$} & \multirow{2}{*}{$\begin{array}{c}3\left((a / W)^{\wedge}(1 /\right. \\
2))\end{array}$} & \multirow{2}{*}{$\begin{array}{c}2(1- \\
(a / W))^{\wedge}(3 / \\
2))\end{array}$} & \multirow{2}{*}{$\begin{array}{c}\text { KIc } \\
\text { MPaVm }\end{array}$} & \multicolumn{2}{|c|}{ Onset Force } & \multirow{2}{*}{$\begin{array}{c}\begin{array}{c}\Sigma A E \text { at } \\
\text { max } \\
\text { load }\end{array} \\
\text { AE } \\
\text { Counts }\end{array}$} & \multirow{2}{*}{$\begin{array}{c}\Sigma \mathrm{AE} \text { at } \\
\text { total } \\
\text { fracture } \\
(50 \mathrm{~N} \text { or } \\
11.24 \mathrm{lbf} \\
\text { load) } \\
\text { AE Counts }\end{array}$} \\
\hline & & & & lbf & $\mathrm{N}$ & & & & & & lbf & $\mathrm{N}$ & & \\
\hline 2114-Block-2-WG-2 & WG & AG & 1 & 34.09 & 148.30 & 0.16 & $4.24 \mathrm{E}-05$ & 1.897 & 0.930 & 1.14 & 33.34 & 148.30 & 1053 & 10772 \\
\hline 2114-Block-2-WG-3 & WG & AG & 1 & 33.19 & 147.63 & 0.16 & $4.24 \mathrm{E}-05$ & 1.897 & 0.930 & 1.14 & 26.95 & 119.87 & 1153 & 13227 \\
\hline 2114-Block-2-WG-4 & WG & AG & 1 & 32.30 & 143.67 & 0.16 & $4.24 \mathrm{E}-05$ & 1.897 & 0.930 & 1.11 & 26.95 & 119.87 & 1289 & 7937 \\
\hline 2114-Block-2-WG-5 & WG & AG & 1 & 34.20 & 152.12 & 0.16 & $4.24 \mathrm{E}-05$ & 1.897 & 0.930 & 1.17 & 29.55 & 131.44 & 984 & 18284 \\
\hline 2114-Block-2-WG-6 & WG & $A G$ & 1 & 33.16 & 147.50 & 0.16 & $4.24 \mathrm{E}-05$ & 1.897 & 0.930 & 1.14 & 27.30 & 121.43 & 715 & 19853 \\
\hline 2114-Block-2-WG-7 & WG & AG & 1 & 33.73 & 150.03 & 0.16 & $4.24 \mathrm{E}-05$ & 1.897 & 0.930 & 1.15 & 26.38 & 117.34 & 1726 & 26582 \\
\hline 2114-Block-2-WG-8 & WG & AG & 1 & 33.30 & 148.12 & 0.16 & $4.24 \mathrm{E}-05$ & 1.897 & 0.930 & 1.14 & 28.61 & 127.26 & 1870 & 20658 \\
\hline 2114-Block-2-WG-9 & WG & AG & 1 & 34.58 & 153.81 & 0.16 & $4.24 \mathrm{E}-05$ & 1.897 & 0.930 & 1.18 & 32.33 & 143.80 & 600 & 6308 \\
\hline 2114-Block-2-WG-10 & WG & $A G$ & 1 & 33.23 & 147.81 & 0.16 & $4.24 \mathrm{E}-05$ & 1.897 & 0.930 & 1.14 & 29.48 & 131.13 & 1521 & 10233 \\
\hline 2114-Block-2-WG-11 & WG & $A G$ & 1 & 34.02 & 151.32 & 0.16 & $4.24 \mathrm{E}-05$ & 1.897 & 0.930 & 1.16 & 28.55 & 126.99 & 1498 & 26485 \\
\hline 2114-Block-2-WG-12 & WG & $A G$ & 1 & 32.66 & 145.27 & 0.16 & $4.24 \mathrm{E}-05$ & 1.897 & 0.930 & 1.12 & 27.52 & 122.41 & 1564 & 19721 \\
\hline 2114-Block-2-WG-13 & WG & $A G$ & 1 & 34.02 & 151.32 & 0.16 & $4.24 \mathrm{E}-05$ & 1.897 & 0.930 & 1.16 & 26.33 & 117.12 & 1634 & 20640 \\
\hline 2114-Block-2-WG-14 & WG & $A G$ & 1 & 33.42 & 148.65 & 0.16 & $4.24 \mathrm{E}-05$ & 1.897 & 0.930 & 1.14 & 30.66 & 136.38 & 693 & 11455 \\
\hline 2114-Block-2-WG-15 & WG & $A G$ & 1 & 31.64 & 140.73 & 0.16 & $4.24 \mathrm{E}-05$ & 1.897 & 0.930 & 1.08 & 30.52 & 135.75 & 697 & 7453 \\
\hline 2114-Block-2-WG-18 & WG & AG & 1 & 34.42 & 153.10 & 0.16 & $4.24 \mathrm{E}-05$ & 1.897 & 0.930 & 1.18 & 27.91 & 124.14 & 1438 & 11028 \\
\hline 2114-Block-2-WG-19 & WG & AG & 1 & 32.77 & 145.76 & 0.16 & $4.24 \mathrm{E}-05$ & 1.897 & 0.930 & 1.12 & 29.42 & 130.86 & 2447 & 16047 \\
\hline 2114-Block-2-WG-20 & WG & $A G$ & 1 & 33.95 & 151.01 & 0.16 & $4.24 \mathrm{E}-05$ & 1.897 & 0.930 & 1.16 & 28.31 & 125.92 & 920 & 7545 \\
\hline 2114-Block-2-WG-21 & WG & $A G$ & 1 & 31.34 & 139.40 & 0.16 & $4.24 \mathrm{E}-05$ & 1.897 & 0.930 & 1.07 & 27.59 & 122.72 & 1872 & 8953 \\
\hline 2114-Block-2-WG-22 & WG & $A G$ & 1 & 32.11 & 142.83 & 0.16 & $4.24 \mathrm{E}-05$ & 1.897 & 0.930 & 1.10 & 17.70 & 78.73 & 1722 & 16293 \\
\hline 2114-Block-2-WG-23 & WG & AG & 1 & 32.97 & 146.65 & 0.16 & $4.24 \mathrm{E}-05$ & 1.897 & 0.930 & 1.13 & 27.77 & 123.52 & 1325 & 13988 \\
\hline 2114-Block-2-WG-24 & WG & $A G$ & 1 & 31.31 & 139.27 & 0.16 & $4.24 \mathrm{E}-05$ & 1.897 & 0.930 & 1.07 & 27.17 & 120.85 & 856 & 7291 \\
\hline 2114-Block-2-WG-25 & WG & $A G$ & 1 & 34.94 & 155.41 & 0.16 & $4.24 \mathrm{E}-05$ & 1.897 & 0.930 & 1.20 & 29.13 & 129.57 & 1028 & 6920 \\
\hline
\end{tabular}




\begin{tabular}{|c|c|c|c|c|c|c|c|c|c|c|c|c|c|c|}
\hline 2114-Block-2-WG-26 & WG & $A G$ & 1 & 33.25 & 147.90 & 0.16 & $4.24 \mathrm{E}-05$ & 1.897 & 0.930 & 1.14 & 20.33 & 90.43 & 2695 & 8785 \\
\hline 2114-Block-2-WG-27 & WG & $A G$ & 1 & \multicolumn{2}{|c|}{ ERROR } & 0.16 & $4.24 \mathrm{E}-05$ & 1.897 & 0.930 & \multicolumn{5}{|c|}{ ERROR } \\
\hline 2114-Block-2-WG-28 & WG & $A G$ & 1 & 33.41 & 148.61 & 0.16 & $4.24 \mathrm{E}-05$ & 1.897 & 0.930 & 1.14 & 29.56 & 131.48 & 657 & 13574 \\
\hline 2114-Block-2-WG-29 & WG & $A G$ & 1 & 31.56 & 140.38 & 0.16 & $4.24 \mathrm{E}-05$ & 1.897 & 0.930 & 1.08 & 27.62 & 122.85 & 1771 & 8092 \\
\hline 2114-Block-2-WG-30 & WG & $A G$ & 1 & 33.16 & 147.50 & 0.16 & $4.24 \mathrm{E}-05$ & 1.897 & 0.930 & 1.14 & 27.84 & 123.83 & 1877 & 11602 \\
\hline 2114-Block-2-WG-31 & WG & $A G$ & 1 & 33.48 & 148.92 & 0.16 & $4.24 \mathrm{E}-05$ & 1.897 & 0.930 & 1.15 & 30.56 & 135.93 & 702 & 11784 \\
\hline 2114-Block-4-WG-2 & WG & AG & 1 & 33.28 & 148.03 & 0.16 & $4.24 \mathrm{E}-05$ & 1.897 & 0.930 & 1.14 & 27.52 & 122.41 & 2236 & 10301 \\
\hline 2114-Block-4-WG-3 & WG & $A G$ & 1 & 34.70 & 154.35 & 0.16 & $4.24 \mathrm{E}-05$ & 1.897 & 0.930 & 1.19 & 28.50 & 126.77 & 669 & 8957 \\
\hline 2114-Block-4-WG-4 & WG & $A G$ & 1 & 34.53 & 153.59 & 0.16 & $4.24 \mathrm{E}-05$ & 1.897 & 0.930 & 1.18 & 27.00 & 120.10 & 1604 & 9800 \\
\hline 2114-Block-4-WG-5 & WG & $A G$ & 1 & \multicolumn{2}{|c|}{ ERROR } & 0.16 & $4.24 \mathrm{E}-05$ & 1.897 & 0.930 & \multicolumn{5}{|c|}{ ERROR } \\
\hline 2114-Block-4-WG-6 & WG & $A G$ & 1 & 34.81 & 154.83 & 0.16 & $4.24 \mathrm{E}-05$ & 1.897 & 0.930 & 1.19 & 20.55 & 91.41 & 2435 & 37007 \\
\hline 2114-Block-4-WG-7 & WG & AG & 1 & 34.94 & 155.41 & 0.16 & $4.24 \mathrm{E}-05$ & 1.897 & 0.930 & 1.20 & 30.19 & 134.29 & 1320 & 9405 \\
\hline 2114-Block-4-WG-8 & WG & $A G$ & 1 & 34.31 & 152.61 & 0.16 & $4.24 \mathrm{E}-05$ & 1.897 & 0.930 & 1.17 & 28.91 & 128.59 & 2665 & 33905 \\
\hline 2114-Block-4-WG-9 & WG & $A G$ & 1 & 34.14 & 151.85 & 0.16 & $4.24 \mathrm{E}-05$ & 1.897 & 0.930 & 1.17 & 27.64 & 122.94 & 1134 & 19987 \\
\hline 2114-Block-4-WG-10 & WG & $A G$ & 1 & 33.77 & 150.21 & 0.16 & $4.24 \mathrm{E}-05$ & 1.897 & 0.930 & 1.16 & 30.09 & 133.84 & 2877 & 22462 \\
\hline 2114-Block-4-WG-11 & WG & $A G$ & 1 & 35.20 & 156.57 & 0.16 & $4.24 \mathrm{E}-05$ & 1.897 & 0.930 & 1.21 & 31.36 & 139.49 & 1965 & 17828 \\
\hline 2114-Block-4-WG-12 & WG & $A G$ & 1 & 35.08 & 156.04 & 0.16 & $4.24 \mathrm{E}-05$ & 1.897 & 0.930 & 1.20 & 25.09 & 111.60 & 1565 & 39453 \\
\hline 2114-Block-4-WG-13 & WG & $A G$ & 1 & 35.19 & 156.53 & 0.16 & $4.24 \mathrm{E}-05$ & 1.897 & 0.930 & 1.20 & 29.66 & 131.93 & 745 & 46895 \\
\hline 2114-Block-4-WG-14 & WG & $A G$ & 1 & 34.09 & 151.63 & 0.16 & $4.24 \mathrm{E}-05$ & 1.897 & 0.930 & 1.17 & 28.47 & 126.63 & 1739 & 29652 \\
\hline 2114-Block-4-WG-15 & WG & $A G$ & 1 & 35.08 & 156.04 & 0.16 & $4.24 \mathrm{E}-05$ & 1.897 & 0.930 & 1.20 & 33.48 & 148.92 & 464 & 5359 \\
\hline 2114-Block-4-WG-18 & WG & $A G$ & 1 & 34.33 & 152.70 & 0.16 & $4.24 \mathrm{E}-05$ & 1.897 & 0.930 & 1.18 & 27.66 & 123.03 & 1771 & 15318 \\
\hline 2114-Block-4-WG-19 & WG & $A G$ & 1 & 33.86 & 150.61 & 0.16 & $4.24 \mathrm{E}-05$ & 1.897 & 0.930 & 1.16 & 27.78 & 123.57 & 2081 & 19128 \\
\hline 2114-Block-4-WG-20 & WG & $A G$ & 1 & 30.75 & 136.78 & 0.16 & $4.24 \mathrm{E}-05$ & 1.897 & 0.930 & 1.05 & 28.47 & 126.63 & 1275 & 8560 \\
\hline 2114-Block-4-WG-21 & WG & $A G$ & 1 & 33.44 & 148.74 & 0.16 & $4.24 \mathrm{E}-05$ & 1.897 & 0.930 & 1.15 & 2.88 & 12.81 & 634 & 14525 \\
\hline 2114-Block-4-WG-22 & WG & $A G$ & 1 & 33.80 & 150.34 & 0.16 & $4.24 \mathrm{E}-05$ & 1.897 & 0.930 & 1.16 & 25.50 & 113.42 & 1417 & 10702 \\
\hline 2114-Block-4-WG-23 & WG & $A G$ & 1 & 33.64 & 149.63 & 0.16 & $4.24 \mathrm{E}-05$ & 1.897 & 0.930 & 1.15 & 30.09 & 133.84 & 1776 & 21849 \\
\hline 2114-Block-4-WG-24 & WG & $A G$ & 1 & 34.06 & 151.50 & 0.16 & $4.24 \mathrm{E}-05$ & 1.897 & 0.930 & 1.17 & 30.31 & 134.82 & 954 & 33842 \\
\hline 2114-Block-4-WG-25 & WG & $A G$ & 1 & 33.33 & 148.25 & 0.16 & $4.24 \mathrm{E}-05$ & 1.897 & 0.930 & 1.14 & 23.86 & 106.13 & 3473 & 25938 \\
\hline 2114-Block-4-WG-26 & WG & $A G$ & 1 & 33.14 & 147.41 & 0.16 & $4.24 \mathrm{E}-05$ & 1.897 & 0.930 & 1.13 & 25.17 & 111.96 & 1964 & 20205 \\
\hline 2114-Block-4-WG-27 & WG & $A G$ & 1 & 34.58 & 153.81 & 0.16 & $4.24 \mathrm{E}-05$ & 1.897 & 0.930 & 1.18 & 31.67 & 140.87 & 564 & 9827 \\
\hline
\end{tabular}




\begin{tabular}{|c|c|c|c|c|c|c|c|c|c|c|c|c|c|c|}
\hline 2114-Block-4-WG-28 & WG & AG & 1 & 34.03 & 151.37 & 0.16 & $4.24 \mathrm{E}-05$ & 1.897 & 0.930 & 1.17 & 28.72 & 127.75 & 1906 & 16275 \\
\hline 2114-Block-4-WG-29 & WG & AG & 1 & 33.89 & 150.74 & 0.16 & $4.24 \mathrm{E}-05$ & 1.897 & 0.930 & 1.16 & 27.75 & 123.43 & 3445 & 9671 \\
\hline 2114-Block-4-WG-30 & WG & $A G$ & 1 & 34.72 & 154.43 & 0.16 & 4.24E-05 & 1.897 & 0.930 & 1.19 & 30.25 & 134.55 & 993 & 22103 \\
\hline \multirow[t]{3}{*}{ 2114-Block-4-WG-31 } & WG & $\overline{A G}$ & 1 & 34.27 & 152.43 & 0.16 & $4.24 \mathrm{E}-05$ & 1.897 & 0.930 & 1.17 & 28.67 & 127.52 & 2730 & 27464 \\
\hline & & & & Mean & 149.62 & & & & & 1.15 & 27.64 & 122.95 & 1532 & 16813 \\
\hline & & & & SD & 4.62 & & & & & 0.04 & 4.33 & 19.26 & 725 & 8992 \\
\hline
\end{tabular}


Table $8 \mathrm{~K}_{\mathrm{Ic}}$ and $\mathrm{AE}$ data for grade 2114, AG specimen (WG fracture orientation)

\begin{tabular}{|c|c|c|c|c|c|c|c|c|c|c|c|c|c|c|}
\hline \multicolumn{15}{|c|}{$2114(15 \times 20 \times 200 \mathrm{~mm}, \mathrm{a} / \mathrm{W}=0.40)$} \\
\hline \multirow[t]{2}{*}{ Specimen ID } & \multirow{2}{*}{$\begin{array}{c}\text { Spec } \\
\text { Orie } \\
\text { ntati } \\
\text { on }\end{array}$} & \multirow{2}{*}{$\begin{array}{c}\text { Crac } \\
\text { k } \\
\text { Orie } \\
\text { ntati } \\
\text { on }\end{array}$} & \multirow[t]{2}{*}{ g } & \multicolumn{2}{|c|}{$P(\max )$} & \multirow{2}{*}{$\begin{array}{c}\mathrm{S} \\
\\
\\
\mathrm{M}\end{array}$} & \multirow{2}{*}{$\begin{array}{c}\mathrm{B}^{*}\left(\mathrm{~W}^{\wedge}(3\right. \\
/ 2))\end{array}$} & \multirow{2}{*}{$\begin{array}{c}3\left((a / W)^{\wedge}\right. \\
(1 / 2))\end{array}$} & \multirow{2}{*}{$\begin{array}{c}2(1- \\
(a / W))^{\wedge}(3 \\
/ 2))\end{array}$} & \multirow{2}{*}{$\begin{array}{c}\text { KIc } \\
\text { MPa.Vm }\end{array}$} & \multicolumn{2}{|c|}{ Onset Force } & \multirow{2}{*}{$\begin{array}{c}\begin{array}{c}\sum \mathrm{AE} \text { at } \\
\text { max } \\
\text { load }\end{array} \\
\mathrm{AE} \\
\text { Counts }\end{array}$} & \multirow{2}{*}{$\begin{array}{c}\Sigma A E \text { at } \\
\text { total } \\
\text { fracture } \\
\text { (50 N or } \\
11.24 \mathrm{lbf} \\
\text { load) } \\
\text { AE Counts }\end{array}$} \\
\hline & & & & $\mathrm{Ibf}$ & $\mathrm{N}$ & & & & & & $\mathrm{lbf}$ & $\mathrm{N}$ & & \\
\hline 2114-Block-2-AG-2 & AG & WG & 1 & 34.77 & 154.66 & 0.16 & $4.24 \mathrm{E}-05$ & 1.897 & 0.930 & 1.19 & 33.89 & 150.74 & 2128 & 18609 \\
\hline 2114-Block-2-AG-3 & AG & WG & 1 & 33.52 & 149.10 & 0.16 & $4.24 \mathrm{E}-05$ & 1.897 & 0.930 & 1.15 & 30.92 & 137.53 & 1447 & 19446 \\
\hline 2114-Block-2-AG-4 & AG & WG & 1 & 34.61 & 153.95 & 0.16 & $4.24 \mathrm{E}-05$ & 1.897 & 0.930 & 1.19 & 29.36 & 130.59 & 2798 & 18300 \\
\hline 2114-Block-2-AG-5 & $A G$ & WG & 1 & 33.06 & 147.05 & 0.16 & $4.24 \mathrm{E}-05$ & 1.897 & 0.930 & 1.13 & 30.75 & 136.78 & 1148 & 7844 \\
\hline 2114-Block-2-AG-6 & AG & WG & 1 & 33.25 & 147.90 & 0.16 & $4.24 \mathrm{E}-05$ & 1.897 & 0.930 & 1.14 & 32.02 & 142.42 & 487 & 6796 \\
\hline 2114-Block-2-AG-7 & AG & WG & 1 & 34.06 & 151.50 & 0.16 & $4.24 \mathrm{E}-05$ & 1.897 & 0.930 & 1.17 & 29.88 & 132.91 & 1020 & 7284 \\
\hline 2114-Block-2-AG-8 & $A G$ & WG & 1 & 33.66 & 149.72 & 0.16 & $4.24 \mathrm{E}-05$ & 1.897 & 0.930 & 1.15 & 28.48 & 126.68 & 1746 & 7090 \\
\hline 2114-Block-2-AG-9 & $A G$ & WG & 1 & 33.11 & 147.27 & 0.16 & $4.24 \mathrm{E}-05$ & 1.897 & 0.930 & 1.13 & 28.47 & 126.63 & 1530 & 14231 \\
\hline 2114-Block-2-AG-10 & AG & WG & 1 & 33.80 & 150.34 & 0.16 & $4.24 \mathrm{E}-05$ & 1.897 & 0.930 & 1.16 & 30.23 & 134.46 & 723 & 14783 \\
\hline 2114-Block-2-AG-11 & $A G$ & WG & 1 & 33.72 & 149.99 & 0.16 & $4.24 \mathrm{E}-05$ & 1.897 & 0.930 & 1.15 & 30.94 & 137.62 & 1682 & 17627 \\
\hline 2114-Block-2-AG-12 & AG & WG & 1 & 33.55 & 149.23 & 0.16 & $4.24 \mathrm{E}-05$ & 1.897 & 0.930 & 1.15 & 30.61 & 136.15 & 2286 & 13801 \\
\hline 2114-Block-2-AG-13 & AG & WG & 1 & 34.28 & 152.48 & 0.16 & $4.24 \mathrm{E}-05$ & 1.897 & 0.930 & 1.17 & 25.14 & 111.82 & 3200 & 61041 \\
\hline 2114-Block-2-AG-14 & $A G$ & WG & 1 & 32.44 & 144.29 & 0.16 & $4.24 \mathrm{E}-05$ & 1.897 & 0.930 & 1.11 & 28.02 & 124.63 & 1844 & 10957 \\
\hline 2114-Block-2-AG-15 & AG & WG & 1 & 32.81 & 145.94 & 0.16 & $4.24 \mathrm{E}-05$ & 1.897 & 0.930 & 1.12 & 29.00 & 128.99 & 2438 & 9283 \\
\hline 2114-Block-2-AG-18 & AG & WG & 1 & 33.30 & 148.12 & 0.16 & $4.24 \mathrm{E}-05$ & 1.897 & 0.930 & 1.14 & 27.80 & 123.65 & 2267 & 22766 \\
\hline 2114-Block-2-AG-19 & AG & WG & 1 & 32.98 & 146.70 & 0.16 & $4.24 \mathrm{E}-05$ & 1.897 & 0.930 & 1.13 & 29.77 & 132.42 & 1763 & 5039 \\
\hline 2114-Block-2-AG-20 & AG & WG & 1 & 33.44 & 148.74 & 0.16 & $4.24 \mathrm{E}-05$ & 1.897 & 0.930 & 1.15 & 27.33 & 121.56 & 2869 & 39956 \\
\hline 2114-Block-2-AG-21 & AG & WG & 1 & 33.98 & 151.14 & 0.16 & $4.24 \mathrm{E}-05$ & 1.897 & 0.930 & 1.16 & 30.30 & 134.77 & 1250 & 11975 \\
\hline 2114-Block-2-AG-22 & $A G$ & WG & 1 & 33.33 & 148.25 & 0.16 & $4.24 \mathrm{E}-05$ & 1.897 & 0.930 & 1.14 & 30.02 & 133.53 & 1588 & 12484 \\
\hline 2114-Block-2-AG-23 & AG & WG & 1 & 32.97 & 146.65 & 0.16 & $4.24 \mathrm{E}-05$ & 1.897 & 0.930 & 1.13 & 28.63 & 127.35 & 1453 & 10374 \\
\hline 2114-Block-2-AG-24 & AG & WG & 1 & 32.81 & 145.94 & 0.16 & $4.24 \mathrm{E}-05$ & 1.897 & 0.930 & 1.12 & 23.17 & 103.06 & 1066 & 22923 \\
\hline 2114-Block-2-AG-25 & $A G$ & WG & 1 & 34.08 & 151.59 & 0.16 & $4.24 \mathrm{E}-05$ & 1.897 & 0.930 & 1.17 & 27.75 & 123.43 & 1615 & 15020 \\
\hline
\end{tabular}




\begin{tabular}{|c|c|c|c|c|c|c|c|c|c|c|c|c|c|c|}
\hline 2114-Block-2-AG-26 & $A G$ & WG & 1 & 33.67 & 149.76 & 0.16 & $4.24 \mathrm{E}-05$ & 1.897 & 0.930 & 1.15 & 30.28 & 134.69 & 897 & 20713 \\
\hline 2114-Block-2-AG-27 & AG & WG & 1 & 33.23 & 147.81 & 0.16 & $4.24 \mathrm{E}-05$ & 1.897 & 0.930 & 1.14 & 29.89 & 132.95 & 1733 & 39895 \\
\hline 2114-Block-2-AG-28 & $A G$ & WG & 1 & 32.83 & 146.03 & 0.16 & 4.24E-05 & 1.897 & 0.930 & 1.12 & 28.83 & 128.24 & 1841 & 10635 \\
\hline 2114-Block-2-AG-29 & AG & WG & 1 & 34.28 & 152.48 & 0.16 & $4.24 \mathrm{E}-05$ & 1.897 & 0.930 & 1.17 & 27.97 & 124.41 & 1499 & 21790 \\
\hline 2114-Block-2-AG-30 & AG & WG & 1 & 33.48 & 148.92 & 0.16 & $4.24 \mathrm{E}-05$ & 1.897 & 0.930 & 1.15 & 10.61 & 47.19 & 1461 & 8409 \\
\hline 2114-Block-2-AG-31 & AG & WG & 1 & 33.39 & 148.52 & 0.16 & $4.24 \mathrm{E}-05$ & 1.897 & 0.930 & 1.14 & 28.70 & 127.66 & 1433 & 20701 \\
\hline 2114-Block-4-AG-2 & AG & WG & 1 & 35.23 & 156.70 & 0.16 & $4.24 \mathrm{E}-05$ & 1.897 & 0.930 & 1.21 & 30.02 & 133.53 & 1220 & 15296 \\
\hline 2114-Block-4-AG-3 & $A G$ & WG & 1 & 32.83 & 146.03 & 0.16 & $4.24 \mathrm{E}-05$ & 1.897 & 0.930 & 1.12 & 24.58 & 109.33 & 3234 & 29936 \\
\hline 2114-Block-4-AG-4 & AG & WG & 1 & 34.38 & 152.92 & 0.16 & $4.24 \mathrm{E}-05$ & 1.897 & 0.930 & 1.18 & 31.02 & 137.98 & 1092 & 13689 \\
\hline 2114-Block-4-AG-5 & $A G$ & WG & 1 & 33.08 & 147.14 & 0.16 & $4.24 \mathrm{E}-05$ & 1.897 & 0.930 & 1.13 & 30.08 & 133.80 & 790 & 10858 \\
\hline 2114-Block-4-AG-6 & $A G$ & WG & 1 & 33.59 & 149.41 & 0.16 & $4.24 \mathrm{E}-05$ & 1.897 & 0.930 & 1.15 & 28.33 & 126.01 & 1989 & 8739 \\
\hline 2114-Block-4-AG-7 & AG & WG & 1 & 33.23 & 147.81 & 0.16 & $4.24 \mathrm{E}-05$ & 1.897 & 0.930 & 1.14 & 28.91 & 128.59 & 1704 & 11864 \\
\hline 2114-Block-4-AG-8 & $A G$ & WG & 1 & 32.38 & 144.03 & 0.16 & $4.24 \mathrm{E}-05$ & 1.897 & 0.930 & 1.11 & 28.13 & 125.12 & 547 & 6328 \\
\hline 2114-Block-4-AG-9 & AG & WG & 1 & 33.50 & 149.01 & 0.16 & $4.24 \mathrm{E}-05$ & 1.897 & 0.930 & 1.15 & 30.84 & 137.18 & 867 & 7086 \\
\hline 2114-Block-4-AG-10 & $A G$ & WG & 1 & 31.73 & 141.14 & 0.16 & $4.24 \mathrm{E}-05$ & 1.897 & 0.930 & 1.09 & 24.03 & 106.89 & 1355 & 18986 \\
\hline 2114-Block-4-AG-11 & $A G$ & WG & 1 & 34.19 & 152.08 & 0.16 & $4.24 \mathrm{E}-05$ & 1.897 & 0.930 & 1.17 & 28.66 & 127.48 & 794 & 5311 \\
\hline 2114-Block-4-AG-12 & AG & WG & 1 & 34.36 & 152.83 & 0.16 & $4.24 \mathrm{E}-05$ & 1.897 & 0.930 & 1.18 & 31.30 & 139.22 & 1175 & 14359 \\
\hline 2114-Block-4-AG-13 & AG & WG & 1 & \multicolumn{2}{|c|}{ ERROR } & 0.16 & $4.24 \mathrm{E}-05$ & 1.897 & 0.930 & 0.00 & \multicolumn{4}{|c|}{ ERROR } \\
\hline 2114-Block-4-AG-14 & AG & WG & 1 & 33.25 & 147.90 & 0.16 & $4.24 \mathrm{E}-05$ & 1.897 & 0.930 & 1.14 & 27.78 & 123.57 & 880 & 32525 \\
\hline 2114-Block-4-AG-15 & $A G$ & WG & 1 & 33.64 & 149.63 & 0.16 & $4.24 \mathrm{E}-05$ & 1.897 & 0.930 & 1.15 & 27.34 & 121.61 & 3608 & 18412 \\
\hline 2114-Block-4-AG-18 & $A G$ & WG & 1 & 32.84 & 146.07 & 0.16 & $4.24 \mathrm{E}-05$ & 1.897 & 0.930 & 1.12 & 31.33 & 139.36 & 1698 & 7980 \\
\hline 2114-Block-4-AG-19 & $A G$ & WG & 1 & 33.28 & 148.03 & 0.16 & $4.24 \mathrm{E}-05$ & 1.897 & 0.930 & 1.14 & 28.06 & 124.81 & 672 & 8479 \\
\hline 2114-Block-4-AG-20 & AG & WG & 1 & 33.28 & 148.03 & 0.16 & $4.24 \mathrm{E}-05$ & 1.897 & 0.930 & 1.14 & 29.73 & 132.24 & 1382 & 9807 \\
\hline 2114-Block-4-AG-21 & $A G$ & WG & 1 & 33.20 & 147.67 & 0.16 & $4.24 \mathrm{E}-05$ & 1.897 & 0.930 & 1.14 & 29.67 & 131.97 & 949 & 12141 \\
\hline 2114-Block-4-AG-22 & $A G$ & WG & 1 & 32.05 & 142.56 & 0.16 & $4.24 \mathrm{E}-05$ & 1.897 & 0.930 & 1.10 & 29.30 & 130.33 & 881 & 8345 \\
\hline 2114-Block-4-AG-23 & $A G$ & WG & 1 & 33.75 & 150.12 & 0.16 & $4.24 \mathrm{E}-05$ & 1.897 & 0.930 & 1.16 & 31.20 & 138.78 & 1363 & 11084 \\
\hline 2114-Block-4-AG-24 & $A G$ & WG & 1 & 33.63 & 149.59 & 0.16 & $4.24 \mathrm{E}-05$ & 1.897 & 0.930 & 1.15 & 29.22 & 129.97 & 505 & 5728 \\
\hline 2114-Block-4-AG-25 & AG & WG & 1 & 34.00 & 151.23 & 0.16 & $4.24 \mathrm{E}-05$ & 1.897 & 0.930 & 1.16 & 28.31 & 125.92 & 1003 & 10919 \\
\hline 2114-Block-4-AG-26 & $A G$ & WG & 1 & 33.53 & 149.14 & 0.16 & $4.24 \mathrm{E}-05$ & 1.897 & 0.930 & 1.15 & 28.31 & 125.92 & 1528 & 27756 \\
\hline 2114-Block-4-AG-27 & $A G$ & WG & 1 & 32.64 & 145.18 & 0.16 & $4.24 \mathrm{E}-05$ & 1.897 & 0.930 & 1.12 & 28.92 & 128.64 & 2035 & 12369 \\
\hline
\end{tabular}




\begin{tabular}{|c|c|c|c|c|c|c|c|c|c|c|c|c|c|c|}
\hline 2114-Block-4-AG-28 & $\overline{A G}$ & WG & 1 & 33.56 & 149.27 & 0.16 & $4.24 \mathrm{E}-05$ & 1.897 & 0.930 & 1.15 & 28.11 & 125.03 & 547 & 16745 \\
\hline 2114-Block-4-AG-29 & $\overline{A G}$ & WG & 1 & 32.81 & 145.94 & 0.16 & $4.24 \mathrm{E}-05$ & 1.897 & 0.930 & 1.12 & 25.64 & 114.05 & 931 & 10379 \\
\hline 2114-Block-4-AG-30 & $A G$ & WG & 1 & 33.17 & 147.54 & 0.16 & $4.24 \mathrm{E}-05$ & 1.897 & 0.930 & 1.14 & 30.59 & 136.06 & 2221 & 17049 \\
\hline \multirow[t]{3}{*}{ 2114-Block-4-AG-31 } & $\overline{A G}$ & WG & 1 & 35.34 & 157.19 & 0.16 & $4.24 \mathrm{E}-05$ & 1.897 & 0.930 & 1.21 & 33.44 & 148.74 & 1134 & 25155 \\
\hline & & & & Mean & 148.77 & & & & & 1.15 & & 127.49 & 1503 & 15713 \\
\hline & & & & SD & 3.05 & & & & & 0.02 & & 14.10 & 717 & 10229 \\
\hline
\end{tabular}


Table $9 \mathrm{~K}_{\mathrm{Ic}}$ and $\mathrm{AE}$ data for grade IG-110 (Graphite assumed to be isotropic)

\begin{tabular}{|c|c|c|c|c|c|c|c|c|c|c|c|c|c|c|}
\hline \multicolumn{15}{|c|}{ IG-110 (15x20x200 mm, a/W=0.40) } \\
\hline \multirow{2}{*}{$\begin{array}{l}\text { Specimen } \\
\text { ID }\end{array}$} & \multirow{2}{*}{$\begin{array}{c}\text { Spec } \\
\text { Orie } \\
\text { ntati } \\
\text { on }\end{array}$} & \multirow{2}{*}{$\begin{array}{c}\text { Crack } \\
\text { Orienta } \\
\text { tion }\end{array}$} & \multirow[t]{2}{*}{ g } & \multicolumn{2}{|c|}{$P(\max )$} & \multirow{2}{*}{$\begin{array}{c}S \\
M\end{array}$} & \multirow[t]{2}{*}{$\mathrm{B}^{*}\left(\mathrm{~W}^{\wedge}(3 / 2)\right)$} & \multirow{2}{*}{$\begin{array}{c}3\left((a / W)^{\wedge}\right. \\
(1 / 2))\end{array}$} & \multirow{2}{*}{$\begin{array}{c}2(1- \\
(a / W))^{\wedge}( \\
3 / 2))\end{array}$} & \multirow{2}{*}{$\begin{array}{c}\text { KIc } \\
\text { MPa.Vm }\end{array}$} & \multicolumn{2}{|c|}{ Onset Force } & \multirow{2}{*}{$\begin{array}{c}\begin{array}{c}\Sigma A E \text { at } \\
\text { max } \\
\text { load }\end{array} \\
A E \\
\text { Counts }\end{array}$} & \multirow{2}{*}{$\begin{array}{c}\sum A E \text { at total } \\
\text { fracture (50 } \\
\text { N or } 11.24 \\
\text { lbf load) } \\
\text { AE Counts }\end{array}$} \\
\hline & & & & $\mathrm{lbf}$ & $\mathrm{N}$ & & & & & & lbf & $\mathrm{N}$ & & \\
\hline IG-110/1 & $x$ & $x$ & 1 & 30.48 & 135.58 & 0.16 & $4.243 E-05$ & 1.897 & 0.930 & 1.04 & 29.06 & 129.26 & 642 & 8241 \\
\hline IG-110/2 & $x$ & $x$ & 1 & 31.84 & 141.62 & 0.16 & $4.243 E-05$ & 1.897 & 0.930 & 1.09 & 29.86 & 132.82 & 224 & 9671 \\
\hline IG-110/3 & $x$ & $x$ & 1 & 31.95 & 142.11 & 0.16 & $4.243 E-05$ & 1.897 & 0.930 & 1.09 & 28.83 & 128.24 & 233 & 13478 \\
\hline IG-110/4 & $x$ & $x$ & 1 & 31.17 & 138.64 & 0.16 & $4.243 \mathrm{E}-05$ & 1.897 & 0.930 & 1.07 & 26.58 & 118.23 & 334 & 9914 \\
\hline IG-110/5 & $x$ & $x$ & 1 & 31.73 & 141.14 & 0.16 & $4.243 \mathrm{E}-05$ & 1.897 & 0.930 & 1.09 & 26.61 & 118.36 & 357 & 8825 \\
\hline IG-110/6 & $x$ & $x$ & 1 & 30.77 & 136.86 & 0.16 & $4.243 \mathrm{E}-05$ & 1.897 & 0.930 & 1.05 & 26.64 & 118.49 & 399 & 12438 \\
\hline IG-110/7 & $x$ & $x$ & 1 & 31.88 & 141.80 & 0.16 & $4.243 \mathrm{E}-05$ & 1.897 & 0.930 & 1.09 & 29.13 & 129.57 & 143 & 14181 \\
\hline IG-110/8 & $x$ & $x$ & 1 & 31.63 & 140.69 & 0.16 & $4.243 \mathrm{E}-05$ & 1.897 & 0.930 & 1.08 & 28.86 & 128.37 & 481 & 9717 \\
\hline IG-110/9 & $x$ & $x$ & 1 & 31.08 & 138.24 & 0.16 & $4.243 \mathrm{E}-05$ & 1.897 & 0.930 & 1.06 & 28.16 & 125.26 & 85 & 11846 \\
\hline IG-110/10 & $x$ & $x$ & 1 & 31.61 & 140.60 & 0.16 & $4.243 \mathrm{E}-05$ & 1.897 & 0.930 & 1.08 & 24.03 & 106.89 & 478 & 11904 \\
\hline IG-110/11 & $x$ & $x$ & 1 & 29.44 & 130.95 & 0.16 & $4.243 \mathrm{E}-05$ & 1.897 & 0.930 & 1.01 & 27.06 & 120.36 & 593 & 11047 \\
\hline IG-110/12 & $x$ & $x$ & 1 & 31.73 & 141.14 & 0.16 & $4.243 \mathrm{E}-05$ & 1.897 & 0.930 & 1.09 & 31.39 & 139.62 & 333 & 12184 \\
\hline IG-110/13 & $x$ & $x$ & 1 & 30.88 & 137.35 & 0.16 & $4.243 \mathrm{E}-05$ & 1.897 & 0.930 & 1.06 & 38.67 & 172.00 & 219 & 10521 \\
\hline IG-110/14 & $x$ & $x$ & 1 & 32.05 & 142.56 & 0.16 & $4.243 \mathrm{E}-05$ & 1.897 & 0.930 & 1.10 & 20.8 & 92.52 & 643 & 11009 \\
\hline IG-110/15 & $x$ & $x$ & 1 & 32.56 & 144.83 & 0.16 & $4.243 \mathrm{E}-05$ & 1.897 & 0.930 & 1.11 & 24.42 & 108.62 & 63 & 11228 \\
\hline IG-110/16 & $x$ & $x$ & 1 & 28.34 & 126.06 & 0.16 & $4.243 \mathrm{E}-05$ & 1.897 & 0.930 & 0.97 & 23.75 & 105.64 & 447 & 9265 \\
\hline IG-110/17 & $x$ & $x$ & 1 & 29.92 & 133.08 & 0.16 & $4.243 \mathrm{E}-05$ & 1.897 & 0.930 & 1.02 & 26.67 & 118.63 & 1474 & 12300 \\
\hline IG-110/18 & $x$ & $x$ & 1 & 31.61 & 140.60 & 0.16 & $4.243 \mathrm{E}-05$ & 1.897 & 0.930 & 1.08 & 24.52 & 109.06 & 1630 & 15043 \\
\hline IG-110/19 & $x$ & $x$ & 1 & 31.31 & 139.27 & 0.16 & $4.243 \mathrm{E}-05$ & 1.897 & 0.930 & 1.07 & 25.91 & 115.25 & 307 & 10161 \\
\hline IG-110/20 & $x$ & $x$ & 1 & 31.63 & 140.69 & 0.16 & $4.243 \mathrm{E}-05$ & 1.897 & 0.930 & 1.08 & 28.19 & 125.39 & 760 & 11794 \\
\hline IG-110/21 & $x$ & $x$ & 1 & 31.73 & 141.14 & 0.16 & $4.243 \mathrm{E}-05$ & 1.897 & 0.930 & 1.09 & 27.41 & 121.92 & 222 & 12629 \\
\hline IG-110/22 & $x$ & $x$ & 1 & 32.20 & 143.23 & 0.16 & $4.243 \mathrm{E}-05$ & 1.897 & 0.930 & 1.10 & 30.22 & 134.42 & 795 & 10831 \\
\hline IG-110/23 & $x$ & $x$ & 1 & 31.52 & 140.20 & 0.16 & $4.243 \mathrm{E}-05$ & 1.897 & 0.930 & 1.08 & 29.48 & 131.13 & 1174 & 14337 \\
\hline
\end{tabular}




\begin{tabular}{|c|c|c|c|c|c|c|c|c|c|c|c|c|c|c|}
\hline IG-110/24 & $x$ & $x$ & 1 & 30.86 & 137.27 & 0.16 & $4.243 \mathrm{E}-05$ & 1.897 & 0.930 & 1.06 & 28.38 & 126.23 & 319 & 10683 \\
\hline IG-110/25 & $x$ & $x$ & 1 & 30.56 & 135.93 & 0.16 & $4.243 \mathrm{E}-05$ & 1.897 & 0.930 & 1.05 & 29.67 & 131.97 & 500 & 10711 \\
\hline IG-110/26 & $x$ & $x$ & 1 & 30.94 & 137.62 & 0.16 & 4.243E-05 & 1.897 & 0.930 & 1.06 & 27.22 & 121.07 & 358 & 13217 \\
\hline IG-110/27 & $x$ & $x$ & 1 & 31.34 & 139.40 & 0.16 & $4.243 \mathrm{E}-05$ & 1.897 & 0.930 & 1.07 & 28.97 & 128.86 & 510 & 13519 \\
\hline IG-110/28 & $x$ & $x$ & 1 & 31.48 & 140.02 & 0.16 & 4.243E-05 & 1.897 & 0.930 & 1.08 & 27.17 & 120.85 & 1199 & 12578 \\
\hline IG-110/29 & $x$ & $x$ & 1 & 30.86 & 137.27 & 0.16 & $4.243 \mathrm{E}-05$ & 1.897 & 0.930 & 1.06 & 24.84 & 110.49 & 1368 & 13215 \\
\hline IG-110/30 & $x$ & $x$ & 1 & 29.83 & 132.68 & 0.16 & $4.243 \mathrm{E}-05$ & 1.897 & 0.930 & 1.02 & 27.92 & 124.19 & 450 & 13709 \\
\hline IG-110/31 & $x$ & $x$ & 1 & 31.08 & 138.24 & 0.16 & $4.243 \mathrm{E}-05$ & 1.897 & 0.930 & 1.06 & 28.61 & 127.26 & 1630 & 11240 \\
\hline \multirow[t]{3}{*}{ IG-110/32 } & $x$ & $x$ & 1 & 32.09 & 142.74 & 0.16 & 4.243E-05 & 1.897 & 0.930 & 1.10 & 30.14 & 134.06 & 364 & 14189 \\
\hline & & & & Mean & 138.74 & & & & & 1.07 & & 123.59 & 585 & 11738 \\
\hline & & & & SD & 3.91 & & & & & 0.03 & & 13.42 & 446 & 1738 \\
\hline
\end{tabular}


Table $10 \mathrm{~K}_{\text {Ic }}$ and AE data for grade PCEA, WG specimen (AG fracture orientation)

\begin{tabular}{|c|c|c|c|c|c|c|c|c|c|c|c|c|c|c|}
\hline \multicolumn{15}{|c|}{ PCEA WG (PAR) orientation $(15 \times 20 \times 200 \mathrm{~mm}, \mathrm{a} / \mathrm{W}=0.40)$} \\
\hline \multirow{2}{*}{$\begin{array}{c}\text { Specime } \\
\text { n ID }\end{array}$} & \multirow{2}{*}{$\begin{array}{c}\text { Spec } \\
\text { Orienta } \\
\text { tion } \\
\\
\text { WG }\end{array}$} & \multirow{2}{*}{$\begin{array}{l}\text { Crack } \\
\text { Orient } \\
\text { ation } \\
\\
\text { AG }\end{array}$} & \multirow[t]{2}{*}{ g } & \multicolumn{2}{|c|}{$P(\max )$} & \multirow{2}{*}{$\begin{array}{c}S \\
\\
\\
M\end{array}$} & \multirow[t]{2}{*}{$\mathrm{B}^{*}\left(\mathrm{~W}^{\wedge}(3 / 2)\right)$} & \multirow{2}{*}{$\begin{array}{c}3\left((a / W)^{\wedge}\right. \\
(1 / 2))\end{array}$} & \multirow{2}{*}{$\begin{array}{c}2(1- \\
(a / W))^{\wedge}( \\
3 / 2))\end{array}$} & \multirow{2}{*}{$\begin{array}{c}\text { KIc } \\
\mathrm{MPa} . \mathrm{Vm}\end{array}$} & \multicolumn{2}{|c|}{ Onset Force } & \multirow{2}{*}{$\begin{array}{c}\sum A E \text { at } \\
\text { max } \\
\text { load }\end{array}$} & \multirow{2}{*}{$\begin{array}{c}\begin{array}{c}\Sigma A E \text { at } \\
\text { total } \\
\text { fracture } \\
(50 \mathrm{~N} \text { or } \\
11.24 \mathrm{lbf} \\
\text { load })\end{array} \\
\mathrm{AE} \\
\text { Counts }\end{array}$} \\
\hline & & & & lbf & $\mathrm{N}$ & & & & & & lbf & $\mathrm{N}$ & & \\
\hline 1 & WG & AG & 1 & 43.36 & 192.87 & 0.16 & $4.243 E-05$ & 1.897 & 0.930 & 1.48 & 32.03 & 142.47 & 4437 & 35749 \\
\hline 2 & WG & AG & 1 & 40.81 & 181.52 & 0.16 & $4.243 \mathrm{E}-05$ & 1.897 & 0.930 & 1.40 & 21.60 & 96.08 & 1533 & 25520 \\
\hline 3 & WG & $A G$ & 1 & 40.16 & 178.63 & 0.16 & $4.243 \mathrm{E}-05$ & 1.897 & 0.930 & 1.38 & 10.17 & 45.24 & 2390 & 19050 \\
\hline 4 & WG & $A G$ & 1 & 41.33 & 183.84 & 0.16 & $4.243 \mathrm{E}-05$ & 1.897 & 0.930 & 1.42 & 37.91 & 168.62 & 772 & 30700 \\
\hline 5 & WG & $A G$ & 1 & 42.25 & 187.93 & 0.16 & $4.243 \mathrm{E}-05$ & 1.897 & 0.930 & 1.45 & 15.69 & 69.79 & 2805 & 28561 \\
\hline 6 & WG & $A G$ & 1 & 41.13 & 182.95 & 0.16 & $4.243 \mathrm{E}-05$ & 1.897 & 0.930 & 1.41 & 38.08 & 169.38 & 3105 & 24562 \\
\hline 7 & WG & $A G$ & 1 & 41.41 & 184.19 & 0.16 & $4.243 \mathrm{E}-05$ & 1.897 & 0.930 & 1.42 & 24.34 & 108.26 & 4761 & 40729 \\
\hline 8 & WG & $A G$ & 1 & 43.05 & 191.49 & 0.16 & $4.243 \mathrm{E}-05$ & 1.897 & 0.930 & 1.47 & 37.16 & 165.29 & 1523 & 22813 \\
\hline 9 & WG & $A G$ & 1 & 42.19 & 187.66 & 0.16 & $4.243 E-05$ & 1.897 & 0.930 & 1.44 & 25.75 & 114.54 & 3491 & 30377 \\
\hline 10 & WG & $A G$ & 1 & 42.94 & 191.00 & 0.16 & $4.243 E-05$ & 1.897 & 0.930 & 1.47 & 21.09 & 93.81 & 2986 & 28485 \\
\hline 11 & WG & $A G$ & 1 & 44.47 & 197.80 & 0.16 & $4.243 \mathrm{E}-05$ & 1.897 & 0.930 & 1.52 & 21.34 & 94.92 & 1877 & 30416 \\
\hline 12 & WG & $A G$ & 1 & 41.09 & 182.77 & 0.16 & $4.243 \mathrm{E}-05$ & 1.897 & 0.930 & 1.41 & 29.28 & 130.24 & 5789 & 44433 \\
\hline 13 & WG & $A G$ & 1 & 39.81 & 177.07 & 0.16 & $4.243 \mathrm{E}-05$ & 1.897 & 0.930 & 1.36 & 24.89 & 110.71 & 4294 & 32401 \\
\hline 14 & WG & $A G$ & 1 & 42.52 & 189.13 & 0.16 & $4.243 E-05$ & 1.897 & 0.930 & 1.46 & 27.86 & 123.92 & 3016 & 32940 \\
\hline 15 & WG & $A G$ & 1 & 40.75 & 181.26 & 0.16 & $4.243 \mathrm{E}-05$ & 1.897 & 0.930 & 1.40 & 24.52 & 109.06 & 1066 & 25032 \\
\hline 16 & WG & $A G$ & 1 & 41.28 & 183.61 & 0.16 & $4.243 \mathrm{E}-05$ & 1.897 & 0.930 & 1.41 & 26.44 & 117.61 & 4257 & 29954 \\
\hline 17 & WG & $A G$ & 1 & 40.91 & 181.97 & 0.16 & $4.243 \mathrm{E}-05$ & 1.897 & 0.930 & 1.40 & 30.56 & 135.93 & 2136 & 30591 \\
\hline 18 & WG & $A G$ & 1 & 41.92 & 186.46 & 0.16 & $4.243 E-05$ & 1.897 & 0.930 & 1.44 & 35.52 & 157.99 & 1491 & 20411 \\
\hline 19 & WG & $A G$ & 1 & 42.70 & 189.93 & 0.16 & $4.243 E-05$ & 1.897 & 0.930 & 1.46 & 35.77 & 159.10 & 205 & 8631 \\
\hline 20 & WG & $A G$ & 1 & 42.83 & 190.51 & 0.16 & $4.243 \mathrm{E}-05$ & 1.897 & 0.930 & 1.47 & 29.45 & 130.99 & 3509 & 31582 \\
\hline 21 & WG & $A G$ & 1 & 42.20 & 187.71 & 0.16 & $4.243 E-05$ & 1.897 & 0.930 & 1.44 & 28.55 & 126.99 & 3835 & 35986 \\
\hline 22 & WG & $A G$ & 1 & 41.77 & 185.79 & 0.16 & $4.243 \mathrm{E}-05$ & 1.897 & 0.930 & 1.43 & 26.42 & 117.52 & 6319 & 38339 \\
\hline
\end{tabular}




\begin{tabular}{|c|c|c|c|c|c|c|c|c|c|c|c|c|c|c|}
\hline 23 & WG & $A G$ & 1 & 40.30 & 179.25 & 0.16 & $4.243 \mathrm{E}-05$ & 1.897 & 0.930 & 1.38 & 21.52 & 95.72 & 5543 & 29834 \\
\hline 24 & WG & $A G$ & 1 & 43.45 & 193.27 & 0.16 & $4.243 E-05$ & 1.897 & 0.930 & 1.49 & 29.13 & 129.57 & 2200 & 27514 \\
\hline 25 & WG & $A G$ & 1 & 40.52 & 180.23 & 0.16 & $4.243 \mathrm{E}-05$ & 1.897 & 0.930 & 1.39 & 24.91 & 110.80 & 4616 & 38495 \\
\hline 26 & WG & $A G$ & 1 & 39.45 & 175.47 & 0.16 & $4.243 \mathrm{E}-05$ & 1.897 & 0.930 & 1.35 & 28.02 & 124.63 & 1496 & 25556 \\
\hline 27 & WG & $A G$ & 1 & 41.42 & 184.24 & 0.16 & $4.243 \mathrm{E}-05$ & 1.897 & 0.930 & 1.42 & 31.89 & 141.85 & 2769 & 24581 \\
\hline 28 & WG & $A G$ & 1 & 41.19 & 183.21 & 0.16 & $4.243 \mathrm{E}-05$ & 1.897 & 0.930 & 1.41 & 32.02 & 142.42 & 4044 & 28204 \\
\hline 29 & WG & $A G$ & 1 & 41.95 & 186.59 & 0.16 & $4.243 \mathrm{E}-05$ & 1.897 & 0.930 & 1.44 & 30.28 & 134.69 & 4697 & 32077 \\
\hline 30 & WG & $A G$ & 1 & 39.44 & 175.43 & 0.16 & $4.243 \mathrm{E}-05$ & 1.897 & 0.930 & 1.35 & 26.61 & 118.36 & 3400 & 24835 \\
\hline 31 & WG & $A G$ & 1 & 41.52 & 184.68 & 0.16 & $4.243 \mathrm{E}-05$ & 1.897 & 0.930 & 1.42 & 23.48 & 104.44 & 710 & 19807 \\
\hline 32 & WG & $A G$ & 1 & 40.97 & 182.23 & 0.16 & $4.243 \mathrm{E}-05$ & 1.897 & 0.930 & 1.40 & 29.67 & 131.97 & 2392 & 22120 \\
\hline 33 & WG & $A G$ & 1 & 40.11 & 178.41 & 0.16 & $4.243 \mathrm{E}-05$ & 1.897 & 0.930 & 1.37 & 33.69 & 149.85 & 2244 & 25451 \\
\hline 34 & WG & $A G$ & 1 & 42.75 & 190.15 & 0.16 & $4.243 \mathrm{E}-05$ & 1.897 & 0.930 & 1.46 & 33.75 & 150.12 & 3208 & 27906 \\
\hline 35 & WG & $A G$ & 1 & 43.16 & 191.98 & 0.16 & $4.243 \mathrm{E}-05$ & 1.897 & 0.930 & 1.48 & 27.53 & 122.45 & 1005 & 27353 \\
\hline 36 & WG & $A G$ & 1 & 43.08 & 191.62 & 0.16 & $4.243 \mathrm{E}-05$ & 1.897 & 0.930 & 1.48 & 29.00 & 128.99 & 2915 & 24021 \\
\hline 37 & WG & $A G$ & 1 & 40.88 & 181.83 & 0.16 & $4.243 \mathrm{E}-05$ & 1.897 & 0.930 & 1.40 & 30.48 & 135.58 & 3639 & 25483 \\
\hline 38 & WG & $A G$ & 1 & 42.42 & 188.68 & 0.16 & $4.243 \mathrm{E}-05$ & 1.897 & 0.930 & 1.45 & 35.45 & 157.68 & 1150 & 17289 \\
\hline 39 & WG & $A G$ & 1 & 43.64 & 194.11 & 0.16 & $4.243 \mathrm{E}-05$ & 1.897 & 0.930 & 1.49 & 34.48 & 153.37 & 3474 & 28578 \\
\hline 40 & WG & $A G$ & 1 & 42.03 & 186.95 & 0.16 & $4.243 \mathrm{E}-05$ & 1.897 & 0.930 & 1.44 & 34.63 & 154.03 & 3503 & 35985 \\
\hline 41 & WG & $A G$ & 1 & 43.95 & 195.49 & 0.16 & $4.243 \mathrm{E}-05$ & 1.897 & 0.930 & 1.50 & 37.84 & 168.31 & 1176 & 30191 \\
\hline 42 & WG & $A G$ & 1 & 41.50 & 184.59 & 0.16 & $4.243 \mathrm{E}-05$ & 1.897 & 0.930 & 1.42 & 30.75 & 136.78 & 2451 & 29300 \\
\hline 43 & WG & $A G$ & 1 & 42.64 & 189.66 & 0.16 & $4.243 \mathrm{E}-05$ & 1.897 & 0.930 & 1.46 & 33.27 & 147.98 & 3911 & 22513 \\
\hline 44 & WG & $A G$ & 1 & 42.42 & 188.68 & 0.16 & $4.243 \mathrm{E}-05$ & 1.897 & 0.930 & 1.45 & 23.39 & 104.04 & 2158 & 24498 \\
\hline 45 & WG & $A G$ & 1 & 42.23 & 187.84 & 0.16 & $4.243 \mathrm{E}-05$ & 1.897 & 0.930 & 1.45 & 36.70 & 163.24 & 1059 & 22596 \\
\hline 46 & WG & $A G$ & 1 & 42.50 & 189.04 & 0.16 & $4.243 \mathrm{E}-05$ & 1.897 & 0.930 & 1.46 & 33.84 & 150.52 & 2471 & 30253 \\
\hline 47 & WG & $A G$ & 1 & 42.91 & 190.86 & 0.16 & $4.243 \mathrm{E}-05$ & 1.897 & 0.930 & 1.47 & 31.03 & 138.02 & 729 & 26748 \\
\hline 48 & WG & $A G$ & 1 & 41.24 & 183.44 & 0.16 & $4.243 \mathrm{E}-05$ & 1.897 & 0.930 & 1.41 & 53.33 & 237.21 & 1758 & 21367 \\
\hline 49 & WG & $A G$ & 1 & 42.02 & 186.90 & 0.16 & $4.243 \mathrm{E}-05$ & 1.897 & 0.930 & 1.44 & 33.22 & 147.76 & 2678 & 29301 \\
\hline 50 & WG & $A G$ & 1 & 42.19 & 187.66 & 0.16 & $4.243 \mathrm{E}-05$ & 1.897 & 0.930 & 1.44 & 24.22 & 107.73 & 2880 & 24097 \\
\hline 51 & WG & $A G$ & 1 & 46.30 & 205.94 & 0.16 & $4.243 \mathrm{E}-05$ & 1.897 & 0.930 & 1.59 & 35.58 & 158.26 & 2752 & 21350 \\
\hline 52 & WG & $A G$ & 1 & 43.52 & 193.58 & 0.16 & $4.243 \mathrm{E}-05$ & 1.897 & 0.930 & 1.49 & 29.59 & 131.62 & 3591 & 24394 \\
\hline
\end{tabular}




\begin{tabular}{|c|c|c|c|c|c|c|c|c|c|c|c|c|c|c|}
\hline 53 & WG & $A G$ & 1 & 44.14 & 196.33 & 0.16 & $4.243 E-05$ & 1.897 & 0.930 & 1.51 & 28.00 & 124.54 & 2581 & 23293 \\
\hline 54 & WG & $A G$ & 1 & 42.13 & 187.39 & 0.16 & $4.243 \mathrm{E}-05$ & 1.897 & 0.930 & 1.44 & 24.45 & 108.75 & 2847 & 27831 \\
\hline 55 & WG & $A G$ & 1 & 41.22 & 183.35 & 0.16 & $4.243 E-05$ & 1.897 & 0.930 & 1.41 & 23.81 & 105.91 & 1460 & 16809 \\
\hline 56 & WG & $A G$ & 1 & 43.73 & 194.51 & 0.16 & $4.243 \mathrm{E}-05$ & 1.897 & 0.930 & 1.50 & 34.97 & 155.55 & 1849 & 22870 \\
\hline 57 & WG & $A G$ & 1 & 46.94 & 208.79 & 0.16 & $4.243 \mathrm{E}-05$ & 1.897 & 0.930 & 1.61 & 33.05 & 147.01 & 1397 & 17864 \\
\hline 58 & WG & $A G$ & 1 & 44.20 & 196.60 & 0.16 & $4.243 E-05$ & 1.897 & 0.930 & 1.51 & 33.31 & 148.16 & 3505 & 23493 \\
\hline 59 & WG & $A G$ & 1 & 45.44 & 202.12 & 0.16 & $4.243 \mathrm{E}-05$ & 1.897 & 0.930 & 1.56 & 31.94 & 142.07 & 3114 & 23056 \\
\hline 60 & WG & $A G$ & 1 & 45.94 & 204.34 & 0.16 & $4.243 \mathrm{E}-05$ & 1.897 & 0.930 & 1.57 & 36.05 & 160.35 & 2262 & 28776 \\
\hline 61 & WG & $A G$ & 1 & 44.38 & 197.40 & 0.16 & $4.243 \mathrm{E}-05$ & 1.897 & 0.930 & 1.52 & 41.52 & 184.68 & 702 & 14357 \\
\hline 62 & WG & $A G$ & 1 & 45.25 & 201.27 & 0.16 & $4.243 E-05$ & 1.897 & 0.930 & 1.55 & 33.75 & 150.12 & 778 & 18215 \\
\hline 63 & WG & $A G$ & 1 & 44.63 & 198.51 & 0.16 & $4.243 E-05$ & 1.897 & 0.930 & 1.53 & 39.20 & 174.36 & 1000 & 16201 \\
\hline 64 & WG & $A G$ & 1 & 43.28 & 192.51 & 0.16 & $4.243 \mathrm{E}-05$ & 1.897 & 0.930 & 1.48 & 31.09 & 138.29 & 5671 & 38815 \\
\hline 65 & WG & $A G$ & 1 & 45.05 & 200.38 & 0.16 & $4.243 \mathrm{E}-05$ & 1.897 & 0.930 & 1.54 & 33.33 & 148.25 & 1000 & 16194 \\
\hline 66 & WG & $A G$ & 1 & 42.81 & 190.42 & 0.16 & $4.243 \mathrm{E}-05$ & 1.897 & 0.930 & 1.47 & 25.25 & 112.31 & 4599 & 26816 \\
\hline 67 & WG & $A G$ & 1 & 45.13 & 200.74 & 0.16 & $4.243 E-05$ & 1.897 & 0.930 & 1.55 & 16.14 & 71.79 & 2290 & 23568 \\
\hline 68 & WG & $A G$ & 1 & 46.16 & 205.32 & 0.16 & $4.243 \mathrm{E}-05$ & 1.897 & 0.930 & 1.58 & 35.55 & 158.13 & 3082 & 21736 \\
\hline 69 & WG & $A G$ & 1 & 42.91 & 190.86 & 0.16 & $4.243 \mathrm{E}-05$ & 1.897 & 0.930 & 1.47 & 37.89 & 168.53 & 1093 & 14163 \\
\hline 70 & WG & $A G$ & 1 & 46.08 & 204.96 & 0.16 & $4.243 \mathrm{E}-05$ & 1.897 & 0.930 & 1.58 & 34.77 & 154.66 & 1456 & 14056 \\
\hline 71 & WG & $A G$ & 1 & 43.30 & 192.60 & 0.16 & $4.243 E-05$ & 1.897 & 0.930 & 1.48 & 31.72 & 141.09 & 2887 & 34545 \\
\hline 72 & WG & $A G$ & 1 & 44.08 & 196.07 & 0.16 & $4.243 E-05$ & 1.897 & 0.930 & 1.51 & 36.22 & 161.11 & 1005 & 15303 \\
\hline 73 & WG & $A G$ & 1 & 43.92 & 195.36 & 0.16 & $4.243 \mathrm{E}-05$ & 1.897 & 0.930 & 1.50 & 30.48 & 135.58 & 3245 & 13706 \\
\hline 74 & WG & $A G$ & 1 & 44.38 & 197.40 & 0.16 & $4.243 \mathrm{E}-05$ & 1.897 & 0.930 & 1.52 & 30.92 & 137.53 & 3212 & 32921 \\
\hline 75 & WG & $A G$ & 1 & 45.20 & 201.05 & 0.16 & $4.243 \mathrm{E}-05$ & 1.897 & 0.930 & 1.55 & 26.80 & 119.21 & 801 & 14184 \\
\hline 76 & WG & $A G$ & 1 & 43.19 & 192.11 & 0.16 & $4.243 \mathrm{E}-05$ & 1.897 & 0.930 & 1.48 & 21.41 & 95.23 & 493 & 18771 \\
\hline 77 & WG & $A G$ & 1 & 43.73 & 194.51 & 0.16 & $4.243 E-05$ & 1.897 & 0.930 & 1.50 & 32.83 & 146.03 & 910 & 16602 \\
\hline 78 & WG & $A G$ & 1 & 45.95 & 204.39 & 0.16 & $4.243 \mathrm{E}-05$ & 1.897 & 0.930 & 1.57 & 33.06 & 147.05 & 1764 & 19228 \\
\hline 79 & WG & $A G$ & 1 & 44.17 & 196.47 & 0.16 & $4.243 \mathrm{E}-05$ & 1.897 & 0.930 & 1.51 & 31.69 & 140.96 & 1191 & 17845 \\
\hline 80 & WG & $A G$ & 1 & 44.59 & 198.34 & 0.16 & $4.243 \mathrm{E}-05$ & 1.897 & 0.930 & 1.53 & 35.16 & 156.39 & 1684 & 14945 \\
\hline 81 & WG & $A G$ & 1 & 45.17 & 200.92 & 0.16 & $4.243 \mathrm{E}-05$ & 1.897 & 0.930 & 1.55 & 31.19 & 138.73 & 2711 & 26095 \\
\hline 82 & WG & $A G$ & 1 & 43.67 & 194.24 & 0.16 & 4.243E-05 & 1.897 & 0.930 & 1.50 & 30.64 & 136.29 & 1548 & 13227 \\
\hline
\end{tabular}




\begin{tabular}{|c|c|c|c|c|c|c|c|c|c|c|c|c|c|c|}
\hline 83 & WG & AG & 1 & 45.69 & 203.23 & 0.16 & $4.243 \mathrm{E}-05$ & 1.897 & 0.930 & 1.56 & 28.69 & 127.61 & 2446 & 19372 \\
\hline 84 & WG & AG & 1 & 44.73 & 198.96 & 0.16 & $4.243 \mathrm{E}-05$ & 1.897 & 0.930 & 1.53 & 37.73 & 167.82 & 898 & 14848 \\
\hline 85 & WG & AG & 1 & 45.52 & 202.47 & 0.16 & 4.243E-05 & 1.897 & 0.930 & 1.56 & 35.48 & 157.82 & 1721 & 21557 \\
\hline 86 & WG & $A G$ & 1 & 43.63 & 194.07 & 0.16 & $4.243 \mathrm{E}-05$ & 1.897 & 0.930 & 1.49 & 31.97 & 142.20 & 1775 & 21024 \\
\hline 87 & WG & AG & 1 & 43.67 & 194.24 & 0.16 & $4.243 \mathrm{E}-05$ & 1.897 & 0.930 & 1.50 & 25.20 & 112.09 & 3086 & 24318 \\
\hline 88 & WG & AG & 1 & 43.09 & 191.66 & 0.16 & $4.243 \mathrm{E}-05$ & 1.897 & 0.930 & 1.48 & 31.56 & 140.38 & 2779 & 23439 \\
\hline 89 & WG & AG & 1 & 44.44 & 197.67 & 0.16 & $4.243 \mathrm{E}-05$ & 1.897 & 0.930 & 1.52 & 35.09 & 156.08 & 1409 & 21010 \\
\hline 90 & WG & $A G$ & 1 & 46.03 & 204.74 & 0.16 & $4.243 \mathrm{E}-05$ & 1.897 & 0.930 & 1.58 & 39.11 & 173.96 & 371 & 21345 \\
\hline 91 & WG & $A G$ & 1 & 44.09 & 196.11 & 0.16 & $4.243 \mathrm{E}-05$ & 1.897 & 0.930 & 1.51 & 27.48 & 122.23 & 1964 & 19446 \\
\hline 92 & WG & $A G$ & 1 & 46.88 & 208.52 & 0.16 & $4.243 \mathrm{E}-05$ & 1.897 & 0.930 & 1.61 & 38.80 & 172.58 & 1611 & 18068 \\
\hline 93 & WG & AG & 1 & 42.81 & 190.42 & 0.16 & $4.243 \mathrm{E}-05$ & 1.897 & 0.930 & 1.47 & 27.59 & 122.72 & 1016 & 15203 \\
\hline 94 & WG & AG & 1 & 45.56 & 202.65 & 0.16 & $4.243 \mathrm{E}-05$ & 1.897 & 0.930 & 1.56 & 36.58 & 162.71 & 341 & 13760 \\
\hline 95 & WG & AG & 1 & 46.50 & 206.83 & 0.16 & $4.243 \mathrm{E}-05$ & 1.897 & 0.930 & 1.59 & 24.19 & 107.60 & 1486 & 17939 \\
\hline 96 & WG & AG & 1 & 44.36 & 197.31 & 0.16 & 4.243E-05 & 1.897 & 0.930 & 1.52 & 32.44 & 144.29 & 2361 & 20620 \\
\hline 97 & WG & $A G$ & 1 & 44.77 & 199.14 & 0.16 & $4.243 \mathrm{E}-05$ & 1.897 & 0.930 & 1.53 & 34.69 & 154.30 & 1568 & 18041 \\
\hline 98 & WG & $A G$ & 1 & 44.30 & 197.05 & 0.16 & $4.243 \mathrm{E}-05$ & 1.897 & 0.930 & 1.52 & 37.36 & 166.18 & 867 & 18274 \\
\hline 99 & WG & AG & 1 & 42.81 & 190.42 & 0.16 & $4.243 \mathrm{E}-05$ & 1.897 & 0.930 & 1.47 & 28.72 & 127.75 & 2300 & 22060 \\
\hline 100 & WG & AG & 1 & 41.06 & 182.63 & 0.16 & $4.243 \mathrm{E}-05$ & 1.897 & 0.930 & 1.41 & 38.83 & 172.72 & 1143 & 14030 \\
\hline 101 & WG & AG & 1 & 41.30 & 183.70 & 0.16 & 4.243E-05 & 1.897 & 0.930 & 1.41 & 31.00 & 137.89 & 667 & 11278 \\
\hline 102 & WG & $A G$ & 1 & 43.75 & 194.60 & 0.16 & 4.243E-05 & 1.897 & 0.930 & 1.50 & 31.16 & 138.60 & 2084 & 16320 \\
\hline 103 & WG & AG & 1 & 43.70 & 194.38 & 0.16 & $4.243 \mathrm{E}-05$ & 1.897 & 0.930 & 1.50 & 27.84 & 123.83 & 1809 & 15632 \\
\hline 104 & WG & $A G$ & 1 & 43.78 & 194.73 & 0.16 & $4.243 \mathrm{E}-05$ & 1.897 & 0.930 & 1.50 & 28.27 & 125.74 & 938 & 19574 \\
\hline 105 & WG & AG & 1 & 42.88 & 190.73 & 0.16 & $4.243 \mathrm{E}-05$ & 1.897 & 0.930 & 1.47 & 33.39 & 148.52 & 1566 & 20127 \\
\hline 106 & WG & AG & 1 & 44.50 & 197.94 & 0.16 & $4.243 \mathrm{E}-05$ & 1.897 & 0.930 & 1.52 & 26.86 & 119.47 & 1087 & 18967 \\
\hline 107 & WG & AG & 1 & 45.56 & 202.65 & 0.16 & 4.243E-05 & 1.897 & 0.930 & 1.56 & 36.72 & 163.33 & 1740 & 27702 \\
\hline 108 & WG & AG & 1 & 43.89 & 195.22 & 0.16 & $4.243 \mathrm{E}-05$ & 1.897 & 0.930 & 1.50 & 29.33 & 130.46 & 2915 & 24105 \\
\hline 109 & WG & $A G$ & 1 & 43.75 & 194.60 & 0.16 & $4.243 \mathrm{E}-05$ & 1.897 & 0.930 & 1.50 & 21.03 & 93.54 & 590 & 17429 \\
\hline 110 & WG & AG & 1 & 46.81 & 208.21 & 0.16 & $4.243 \mathrm{E}-05$ & 1.897 & 0.930 & 1.60 & 25.81 & 114.80 & 1797 & 20208 \\
\hline 111 & WG & AG & 1 & 44.66 & 198.65 & 0.16 & $4.243 \mathrm{E}-05$ & 1.897 & 0.930 & 1.53 & 32.80 & 145.89 & 2303 & 25544 \\
\hline 112 & WG & AG & 1 & 44.95 & 199.94 & 0.16 & $4.243 \mathrm{E}-05$ & 1.897 & 0.930 & 1.54 & 22.95 & 102.08 & 940 & 19030 \\
\hline
\end{tabular}




\begin{tabular}{|c|c|c|c|c|c|c|c|c|c|c|c|c|c|c|}
\hline 113 & WG & AG & 1 & 45.36 & 201.76 & 0.16 & $4.243 \mathrm{E}-05$ & 1.897 & 0.930 & 1.55 & 33.80 & 150.34 & 2372 & 25110 \\
\hline 114 & WG & $A G$ & 1 & 45.39 & 201.89 & 0.16 & $4.243 \mathrm{E}-05$ & 1.897 & 0.930 & 1.55 & 34.44 & 153.19 & 1156 & 16514 \\
\hline 115 & WG & AG & 1 & 45.19 & 201.01 & 0.16 & $4.243 E-05$ & 1.897 & 0.930 & 1.55 & 33.75 & 150.12 & 3766 & 28066 \\
\hline 116 & WG & $A G$ & 1 & 41.53 & 184.73 & 0.16 & $4.243 \mathrm{E}-05$ & 1.897 & 0.930 & 1.42 & 33.00 & 146.78 & 1325 & 27697 \\
\hline 117 & WG & AG & 1 & 42.83 & 190.51 & 0.16 & $4.243 E-05$ & 1.897 & 0.930 & 1.47 & 29.11 & 129.48 & 3264 & 19394 \\
\hline \multirow[t]{3}{*}{118} & WG & $A G$ & 1 & 46.75 & 207.94 & 0.16 & $4.243 \mathrm{E}-05$ & 1.897 & 0.930 & 1.60 & 36.00 & 160.13 & 2211 & 20707 \\
\hline & & & & Mean & 192.62 & & & & & 1.48 & & 136.78 & 2288 & 23578 \\
\hline & & & & SD & 7.97 & & & & & 0.06 & & 26.02 & 1291 & 6821 \\
\hline
\end{tabular}


Table $11 \mathrm{~K}_{\mathrm{Ic}}$ and $\mathrm{AE}$ data for grade PCEA, AG specimen (WG fracture orientation)

\begin{tabular}{|c|c|c|c|c|c|c|c|c|c|c|c|c|c|c|}
\hline \multicolumn{15}{|c|}{ PCEA AG (PER) orientation $(15 \times 20 \times 200 \mathrm{~mm}, \mathrm{a} / \mathrm{W}=\mathbf{0 . 4 0})$} \\
\hline \multirow[t]{2}{*}{$\begin{array}{c}\text { Specime } \\
\text { n ID }\end{array}$} & \multirow{2}{*}{$\begin{array}{c}\begin{array}{c}\text { Spec } \\
\text { Orient } \\
\text { ation }\end{array} \\
\\
\text { AG }\end{array}$} & \multirow{2}{*}{$\begin{array}{c}\text { Crack } \\
\text { Orien } \\
\text { tation }\end{array}$} & \multirow[t]{2}{*}{$\mathrm{g}$} & \multicolumn{2}{|c|}{$P(\max )$} & \multirow{2}{*}{$\begin{array}{l}S \\
M\end{array}$} & \multirow[t]{2}{*}{$\begin{array}{c}\mathrm{B}^{*}\left(\mathrm{~W}^{\wedge}(3 / 2)\right. \\
)\end{array}$} & \multirow[t]{2}{*}{$\begin{array}{c}3\left((a / W)^{\wedge}(1 /\right. \\
2))\end{array}$} & \multirow[t]{2}{*}{$\begin{array}{c}2(1- \\
(a / W))^{\wedge}(3 / 2 \\
))^{-2}\end{array}$} & \multirow{2}{*}{$\begin{array}{c}\mathrm{Klc} \\
\mathrm{MPa} . \mathrm{V} \\
\mathrm{m}\end{array}$} & \multicolumn{2}{|c|}{ Onset Force } & \multirow{2}{*}{$\begin{array}{c}\begin{array}{c}\Sigma A E \text { at } \\
\text { max } \\
\text { load }\end{array} \\
\text { AE } \\
\text { Counts }\end{array}$} & \multirow{2}{*}{ 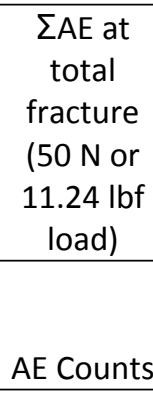 } \\
\hline & & & & $\mathrm{lbf}$ & $\mathrm{N}$ & & & & & & $\mathrm{lbf}$ & $\mathrm{N}$ & & \\
\hline 1 & AG & WG & 1 & 37.94 & 168.76 & 0.16 & 4.243E-05 & 1.897 & 0.930 & 1.30 & 28.5 & 126.77 & 3294 & 27403 \\
\hline 2 & AG & WG & 1 & 37.91 & 168.62 & 0.16 & $4.243 \mathrm{E}-05$ & 1.897 & 0.930 & 1.30 & 4.05 & 18.01 & 4128 & 22595 \\
\hline 3 & AG & WG & 1 & 38.09 & 169.42 & 0.16 & 4.243E-05 & 1.897 & 0.930 & 1.30 & 23.13 & 102.88 & 1926 & 7149 \\
\hline 4 & $A G$ & WG & 1 & 36.83 & 163.82 & 0.16 & 4.243E-05 & 1.897 & 0.930 & 1.26 & 24.75 & 110.09 & 2265 & 24061 \\
\hline 5 & $A G$ & WG & 1 & 38.23 & 170.05 & 0.16 & $4.243 \mathrm{E}-05$ & 1.897 & 0.930 & 1.31 & 32.55 & 144.78 & 1295 & 18248 \\
\hline 6 & $A G$ & WG & 1 & 38.88 & 172.94 & 0.16 & 4.243E-05 & 1.897 & 0.930 & 1.33 & 27.02 & 120.18 & 1836 & 22146 \\
\hline 7 & $\mathrm{AG}$ & WG & 1 & 37.27 & 165.78 & 0.16 & 4.243E-05 & 1.897 & 0.930 & 1.28 & 31.59 & 140.51 & 1177 & 18708 \\
\hline 8 & $A G$ & WG & 1 & 36.72 & 163.33 & 0.16 & 4.243E-05 & 1.897 & 0.930 & 1.26 & 30.72 & 136.64 & 2878 & 20993 \\
\hline 9 & $A G$ & WG & 1 & 36.63 & 162.93 & 0.16 & 4.243E-05 & 1.897 & 0.930 & 1.25 & 31.34 & 139.40 & 2561 & 17332 \\
\hline 10 & $A G$ & WG & 1 & 38.25 & 170.14 & 0.16 & 4.243E-05 & 1.897 & 0.930 & 1.31 & 27.20 & 120.99 & 2669 & 17948 \\
\hline 11 & $A G$ & WG & 1 & 38.00 & 169.02 & 0.16 & $4.243 \mathrm{E}-05$ & 1.897 & 0.930 & 1.30 & 31.05 & 138.11 & 1939 & 25492 \\
\hline 12 & $A G$ & WG & 1 & 38.02 & 169.11 & 0.16 & $4.243 \mathrm{E}-05$ & 1.897 & 0.930 & 1.30 & 27.78 & 123.57 & 1491 & 25606 \\
\hline 13 & $A G$ & WG & 1 & 38.20 & 169.91 & 0.16 & 4.243E-05 & 1.897 & 0.930 & 1.31 & 29.69 & 132.06 & 2794 & 21366 \\
\hline 14 & $\mathrm{AG}$ & WG & 1 & 37.19 & 165.42 & 0.16 & $4.243 \mathrm{E}-05$ & 1.897 & 0.930 & 1.27 & 30.58 & 136.02 & 506 & 19765 \\
\hline 15 & AG & WG & 1 & 36.28 & 161.37 & 0.16 & 4.243E-05 & 1.897 & 0.930 & 1.24 & 25.36 & 112.80 & 1389 & 20452 \\
\hline 16 & $A G$ & WG & 1 & 38.83 & 172.72 & 0.16 & 4.243E-05 & 1.897 & 0.930 & 1.33 & 25.16 & 111.91 & 3971 & 20284 \\
\hline 17 & $A G$ & WG & 1 & 37.84 & 168.31 & 0.16 & 4.243E-05 & 1.897 & 0.930 & 1.30 & 31.41 & 139.71 & 2534 & 24765 \\
\hline 18 & $A G$ & WG & 1 & 37.02 & 164.66 & 0.16 & 4.243E-05 & 1.897 & 0.930 & 1.27 & 19.33 & 85.98 & 1899 & 26736 \\
\hline 19 & AG & WG & 1 & 38.16 & 169.74 & 0.16 & 4.243E-05 & 1.897 & 0.930 & 1.31 & 32.89 & 146.29 & 1260 & 21288 \\
\hline 20 & $A G$ & WG & 1 & 36.66 & 163.06 & 0.16 & 4.243E-05 & 1.897 & 0.930 & 1.26 & 32.44 & 144.29 & 1419 & 23220 \\
\hline 21 & AG & WG & 1 & 38.50 & 171.25 & 0.16 & $4.243 \mathrm{E}-05$ & 1.897 & 0.930 & 1.32 & 28.42 & 126.41 & 492 & 21194 \\
\hline
\end{tabular}




\begin{tabular}{|c|c|c|c|c|c|c|c|c|c|c|c|c|c|c|}
\hline 22 & $A G$ & WG & 1 & 37.84 & 168.31 & 0.16 & 4.243E-05 & 1.897 & 0.930 & 1.30 & 20.52 & 91.27 & 1259 & 29206 \\
\hline 23 & $A G$ & WG & 1 & 38.34 & 170.54 & 0.16 & 4.243E-05 & 1.897 & 0.930 & 1.31 & 31.70 & 141.00 & 3095 & 24336 \\
\hline 24 & $A G$ & WG & 1 & 37.64 & 167.42 & 0.16 & 4.243E-05 & 1.897 & 0.930 & 1.29 & 21.05 & 93.63 & 1689 & 1724 \\
\hline 25 & AG & WG & 1 & 37.11 & 165.07 & 0.16 & 4.243E-05 & 1.897 & 0.930 & 1.27 & 25.16 & 111.91 & 2372 & 20006 \\
\hline 26 & AG & WG & 1 & 38.42 & 170.89 & 0.16 & 4.243E-05 & 1.897 & 0.930 & 1.32 & 30.99 & 137.84 & 817 & 21799 \\
\hline 27 & $A G$ & WG & 1 & 37.02 & 164.66 & 0.16 & 4.243E-05 & 1.897 & 0.930 & 1.27 & 30.53 & 135.80 & 2327 & 20764 \\
\hline 28 & $A G$ & WG & 1 & 38.89 & 172.98 & 0.16 & 4.243E-05 & 1.897 & 0.930 & 1.33 & 32.64 & 145.18 & 2998 & 25038 \\
\hline 29 & $A G$ & WG & 1 & 38.81 & 172.63 & 0.16 & 4.243E-05 & 1.897 & 0.930 & 1.33 & 25.95 & 115.43 & 1156 & 22052 \\
\hline 30 & AG & WG & 1 & 37.02 & 164.66 & 0.16 & 4.243E-05 & 1.897 & 0.930 & 1.27 & 23.89 & 106.26 & 1184 & 15749 \\
\hline 31 & AG & WG & 1 & 36.88 & 164.04 & 0.16 & 4.243E-05 & 1.897 & 0.930 & 1.26 & 26.17 & 116.40 & 1859 & 22394 \\
\hline 32 & $A G$ & WG & 1 & 37.20 & 165.47 & 0.16 & 4.243E-05 & 1.897 & 0.930 & 1.27 & 27.20 & 120.99 & 5388 & 31909 \\
\hline 33 & AG & WG & 1 & 37.86 & 168.40 & 0.16 & 4.243E-05 & 1.897 & 0.930 & 1.30 & 23.61 & 105.02 & 1520 & 13496 \\
\hline 34 & AG & WG & 1 & 38.84 & 172.76 & 0.16 & 4.243E-05 & 1.897 & 0.930 & 1.33 & 23.39 & 104.04 & 1241 & 26466 \\
\hline 35 & AG & WG & 1 & 37.59 & 167.20 & 0.16 & 4.243E-05 & 1.897 & 0.930 & 1.29 & 20.59 & 91.58 & 2541 & 20106 \\
\hline 36 & AG & WG & 1 & 37.42 & 166.44 & 0.16 & 4.243E-05 & 1.897 & 0.930 & 1.28 & 27.34 & 121.61 & 2423 & 21789 \\
\hline 37 & $A G$ & WG & 1 & 36.50 & 162.35 & 0.16 & 4.243E-05 & 1.897 & 0.930 & 1.25 & 24.2 & 107.64 & 5643 & 39300 \\
\hline 38 & AG & WG & 1 & \multirow{2}{*}{\multicolumn{2}{|c|}{ Test Error }} & 0.16 & 4.243E-05 & 1.897 & 0.930 & 0.00 & \multirow{2}{*}{\multicolumn{4}{|c|}{ Test Error }} \\
\hline 39 & AG & WG & 1 & & & 0.16 & 4.243E-05 & 1.897 & 0.930 & 0.00 & & & & \\
\hline 40 & AG & WG & 1 & 38.45 & 171.03 & 0.16 & 4.243E-05 & 1.897 & 0.930 & 1.32 & 28.7 & 127.66 & 2116 & 24798 \\
\hline 41 & AG & WG & 1 & 37.27 & 165.78 & 0.16 & 4.243E-05 & 1.897 & 0.930 & 1.28 & 16.84 & 74.90 & 1766 & 17615 \\
\hline 42 & $\mathrm{AG}$ & WG & 1 & 39.92 & 177.56 & 0.16 & 4.243E-05 & 1.897 & 0.930 & 1.37 & 25.8 & 114.76 & 1246 & 20415 \\
\hline 43 & $A G$ & WG & 1 & 39.48 & 175.61 & 0.16 & 4.243E-05 & 1.897 & 0.930 & 1.35 & 31.83 & 141.58 & 1138 & 19168 \\
\hline 44 & AG & WG & 1 & 38.77 & 172.45 & 0.16 & 4.243E-05 & 1.897 & 0.930 & 1.33 & 26.59 & 118.27 & 2523 & 23824 \\
\hline 45 & AG & WG & 1 & 37.78 & 168.05 & 0.16 & 4.243E-05 & 1.897 & 0.930 & 1.29 & 31.45 & 139.89 & 1849 & 24080 \\
\hline 46 & $A G$ & WG & 1 & 38.53 & 171.38 & 0.16 & $4.243 \mathrm{E}-05$ & 1.897 & 0.930 & 1.32 & 34.27 & 152.43 & 511 & 22520 \\
\hline 47 & $A G$ & WG & 1 & 38.56 & 171.51 & 0.16 & 4.243E-05 & 1.897 & 0.930 & 1.32 & 33.19 & 147.63 & 585 & 20991 \\
\hline 48 & AG & WG & 1 & 37.27 & 165.78 & 0.16 & 4.243E-05 & 1.897 & 0.930 & 1.28 & 24.88 & 110.67 & 2149 & 29039 \\
\hline 49 & AG & WG & 1 & 38.66 & 171.96 & 0.16 & 4.243E-05 & 1.897 & 0.930 & 1.32 & 28.89 & 128.50 & 2245 & 26924 \\
\hline 50 & AG & WG & 1 & 38.7 & 172.14 & 0.16 & 4.243E-05 & 1.897 & 0.930 & 1.33 & 27.3 & 121.43 & 3699 & 25070 \\
\hline 51 & $A G$ & WG & 1 & 39.81 & 177.07 & 0.16 & 4.243E-05 & 1.897 & 0.930 & 1.36 & 24.83 & 110.44 & 1468 & 16145 \\
\hline
\end{tabular}




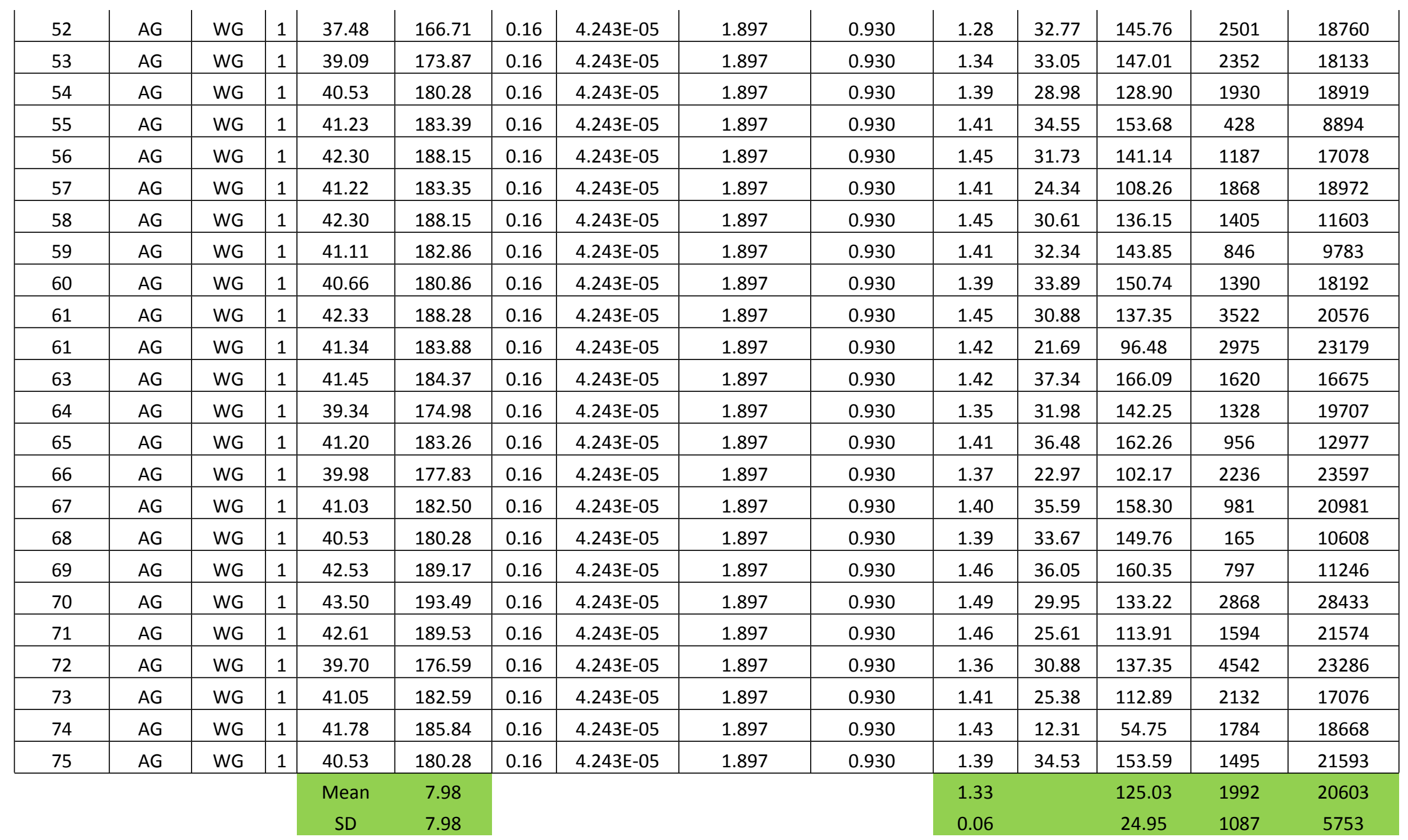


Table $12 \mathrm{~K}_{\mathrm{Ic}}$ and $\mathrm{AE}$ data for grade NBG-18, AG specimen-perpendicular to long axis of billet (WG fracture orientation)

\begin{tabular}{|c|c|c|c|c|c|c|c|c|c|c|c|c|c|c|}
\hline \multicolumn{15}{|c|}{ 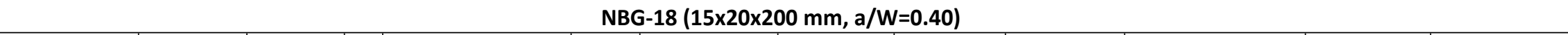 } \\
\hline \multirow[t]{2}{*}{ Specimen ID } & \multirow[t]{2}{*}{$\begin{array}{c}\text { Spec } \\
\text { Orientat } \\
\text { ion }\end{array}$} & \multirow[t]{2}{*}{$\begin{array}{l}\text { Crack } \\
\text { Orient } \\
\text { ation }\end{array}$} & \multirow[t]{2}{*}{$\mathrm{g}$} & \multicolumn{2}{|c|}{$\mathrm{P}(\max )$} & \multirow{2}{*}{$\mathrm{S}$} & \multirow[t]{2}{*}{$\begin{array}{c}\mathrm{B}^{*}\left(\mathrm{~W}^{\wedge}(3 / 2\right. \\
))\end{array}$} & \multirow[t]{2}{*}{$\begin{array}{c}3\left((a / w)^{\wedge}\right. \\
(1 / 2))\end{array}$} & \multirow[t]{2}{*}{$\begin{array}{c}2(1- \\
(a / W))^{\wedge}( \\
3 / 2))\end{array}$} & \multirow{2}{*}{$\begin{array}{c}\text { KIc } \\
\text { MPa.Vm }\end{array}$} & \multicolumn{2}{|c|}{ Onset Force } & \multirow{2}{*}{$\begin{array}{c}\begin{array}{c}\Sigma A E \text { at } \\
\text { max load }\end{array} \\
A E \\
\text { Counts }\end{array}$} & \multirow{2}{*}{ 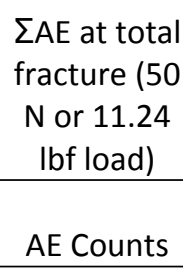 } \\
\hline & & & & $\mathrm{lbf}$ & $\mathrm{N}$ & & & & & & $\mathrm{lbf}$ & $\mathrm{N}$ & & \\
\hline NBG-18-4B & perp 1 & para & 1 & 36.06 & 160.39 & 0.16 & 4.243E-05 & 1.897 & 0.930 & 1.23 & 33.64 & 149.63 & 599 & 26681 \\
\hline NBG-18-4B & perp 2 & para & 1 & 40.42 & 179.79 & 0.16 & 4.243E-05 & 1.897 & 0.930 & 1.38 & 28.91 & 128.59 & 10,095 & 60,693 \\
\hline NBG-18-4B & perp 3 & para & 1 & 43.97 & 195.58 & 0.16 & 4.243E-05 & 1.897 & 0.930 & 1.51 & 25.61 & 113.91 & 1692 & 51,091 \\
\hline NBG-18-4B & perp 4 & para & 1 & 40.98 & 182.28 & 0.16 & 4.243E-05 & 1.897 & 0.930 & 1.40 & 29.48 & 131.13 & 3295 & 39,855 \\
\hline NBG-18-4B & perp 5 & para & 1 & 36.84 & 163.86 & 0.16 & 4.243E-05 & 1.897 & 0.930 & 1.26 & 19.23 & 85.54 & 12177 & 82986 \\
\hline NBG-18-4B & perp 6 & para & 1 & 39.33 & 174.94 & 0.16 & 4.243E-05 & 1.897 & 0.930 & 1.35 & 31.08 & 138.24 & 1181 & 25424 \\
\hline NBG-18-4B & perp 7 & para & 1 & 40.94 & 182.10 & 0.16 & 4.243E-05 & 1.897 & 0.930 & 1.40 & 12.47 & 55.47 & 7345 & 53357 \\
\hline NBG-18-4B & perp 8 & para & 1 & 35.13 & 156.26 & 0.16 & 4.243E-05 & 1.897 & 0.930 & 1.20 & 17.00 & 75.62 & 1777 & 19834 \\
\hline NBG-18-4B & perp 9 & para & 1 & 40.98 & 182.28 & 0.16 & 4.243E-05 & 1.897 & 0.930 & 1.40 & 34.36 & 152.83 & 3400 & 46207 \\
\hline NBG-18-4B & perp 10 & para & 1 & 41.28 & 183.61 & 0.16 & 4.243E-05 & 1.897 & 0.930 & 1.41 & 31.61 & 140.60 & 3319 & 47280 \\
\hline NBG-18-4B & perp 11 & para & 1 & 42.23 & 187.84 & 0.16 & 4.243E-05 & 1.897 & 0.930 & 1.45 & 27.77 & 123.52 & 4311 & 57434 \\
\hline NBG-18-4B & perp 12 & para & 1 & 35.25 & 156.79 & 0.16 & 4.243E-05 & 1.897 & 0.930 & 1.21 & 22.73 & 101.10 & 2690 & 28195 \\
\hline NBG-18-4B & perp 13 & para & 1 & 43.88 & 195.18 & 0.16 & 4.243E-05 & 1.897 & 0.930 & 1.50 & 29.78 & 132.46 & 3412 & 52624 \\
\hline NBG-18-4B & perp 14 & para & 1 & 42.31 & 188.19 & 0.16 & 4.243E-05 & 1.897 & 0.930 & 1.45 & 31.06 & 138.15 & 2247 & 40316 \\
\hline NBG-18-4B & perp 15 & para & 1 & 41.63 & 185.17 & 0.16 & 4.243E-05 & 1.897 & 0.930 & 1.43 & 32.14 & 142.96 & 6122 & 64970 \\
\hline NBG-18 3B & perp 1 & para & 1 & 39.67 & 176.45 & 0.16 & 4.243E-05 & 1.897 & 0.930 & 1.36 & 29.69 & 132.06 & 1170 & 22898 \\
\hline NBG-18 3B & perp 2 & para & 1 & 41.84 & 186.10 & 0.16 & 4.243E-05 & 1.897 & 0.930 & 1.43 & 17.44 & 77.57 & 5012 & 55472 \\
\hline NBG-18 3B & perp 3 & para & 1 & 36.94 & 164.31 & 0.16 & 4.243E-05 & 1.897 & 0.930 & 1.26 & 28.09 & 124.94 & 2168 & 30326 \\
\hline NBG-18 3B & perp 4 & para & 1 & 42.56 & 189.31 & 0.16 & 4.243E-05 & 1.897 & 0.930 & 1.46 & 36.72 & 163.33 & 3388 & 43929 \\
\hline NBG-18 3B & perp 5 & para & 1 & 33.45 & 148.79 & 0.16 & 4.243E-05 & 1.897 & 0.930 & 1.15 & 21.39 & 95.14 & 1768 & 21859 \\
\hline NBG-18 3B & perp 6 & para & 1 & 37.89 & 168.53 & 0.16 & 4.243E-05 & 1.897 & 0.930 & 1.30 & 29.97 & 133.31 & 949 & 20175 \\
\hline NBG-18 3B & perp 7 & para & 1 & 38.69 & 172.09 & 0.16 & 4.243E-05 & 1.897 & 0.930 & 1.32 & 32.78 & 145.81 & 3423 & 46857 \\
\hline NBG-18 3B & perp 8 & para & 1 & 40.14 & 178.54 & 0.16 & 4.243E-05 & 1.897 & 0.930 & 1.37 & 25.39 & 112.93 & 3662 & 32795 \\
\hline
\end{tabular}




\begin{tabular}{|c|c|c|c|c|c|c|c|c|c|c|c|c|c|c|}
\hline NBG-18 3B & perp 9 & para & 1 & 36.41 & 161.95 & 0.16 & $4.243 \mathrm{E}-05$ & 1.897 & 0.930 & 1.25 & 29.24 & 130.06 & 945 & 28084 \\
\hline NBG-18 3B & perp 10 & para & 1 & 41.09 & 182.77 & 0.16 & 4.243E-05 & 1.897 & 0.930 & 1.41 & 34.20 & 152.12 & 3298 & 42977 \\
\hline & & & & Mean & 176.12 & & & & & 1.36 & & 123.08 & 3578 & 41693 \\
\hline
\end{tabular}


Table $13 \mathrm{~K}_{\mathrm{Ic}}$ and AE data for grade NBG-18, WG specimen-parallel to long axis of billet (AG fracture orientation)

\begin{tabular}{|c|c|c|c|c|c|c|c|c|c|c|c|c|c|c|}
\hline \multicolumn{15}{|c|}{ NBG-18 $(15 \times 20 \times 200 \mathrm{~mm}, \mathrm{a} / \mathrm{W}=0.40)$} \\
\hline \multirow[t]{2}{*}{ Spec } & \multirow[t]{2}{*}{$\begin{array}{l}\text { Spec } \\
\text { Orien } \\
\text { tation }\end{array}$} & \multirow[t]{2}{*}{$\begin{array}{c}\text { Crack } \\
\text { Orien } \\
\text { tatio } \\
n \\
\end{array}$} & \multirow[t]{2}{*}{$\mathrm{g}$} & \multicolumn{2}{|c|}{$\mathrm{P}(\max )$} & \multirow[t]{2}{*}{$\mathrm{S}$} & \multirow[t]{2}{*}{$\begin{array}{c}\mathrm{B}^{*}\left(\mathrm{~W}^{\wedge}(3 / 2)\right. \\
)\end{array}$} & \multirow[t]{2}{*}{$\begin{array}{c}3\left((a / W)^{\wedge}(\right. \\
1 / 2))\end{array}$} & \multirow[t]{2}{*}{$\begin{array}{c}2(1- \\
(a / W))^{\wedge}( \\
3 / 2))\end{array}$} & \multirow{2}{*}{$\begin{array}{l}\mathrm{Klc} \\
\mathrm{MPa} \\
. \mathrm{Vm} \\
\end{array}$} & \multicolumn{2}{|c|}{ Onset Force } & \multirow{2}{*}{$\begin{array}{c}\begin{array}{c}\Sigma A E \text { at max } \\
\text { load }\end{array} \\
\text { AE Counts }\end{array}$} & \multirow{2}{*}{$\begin{array}{c}\begin{array}{c}\Sigma \mathrm{AE} \text { at total } \\
\text { fracture (50 N } \\
\text { or } \begin{array}{c}11.24 \mathrm{lbf} \\
\text { load) }\end{array} \\
\text { AE Counts }\end{array} \\
\end{array}$} \\
\hline & & & & $\mathrm{Ibf}$ & $\mathrm{N}$ & & & & & & $\mathrm{lbf}$ & $\mathrm{N}$ & & \\
\hline NBG-18-3B & par 1 & perp & 1 & 36.98 & 164.49 & 0.16 & $4.243 \mathrm{E}-05$ & 1.897 & 0.930 & 1.27 & 22.22 & 98.83 & 5748 & 55674 \\
\hline NBG-18-3B & par 2 & perp & 1 & 43.39 & 193.00 & 0.16 & 4.243E-05 & 1.897 & 0.930 & 1.49 & 25.94 & 115.38 & 3,812 & 48,474 \\
\hline NBG-18-3B & par 3 & perp & 1 & 41.78 & 185.84 & 0.16 & 4.243E-05 & 1.897 & 0.930 & 1.43 & 23.61 & 105.02 & 5325 & 78,777 \\
\hline NBG-18-3B & par 4 & perp & 1 & 41.28 & 183.61 & 0.16 & 4.243E-05 & 1.897 & 0.930 & 1.41 & 29.48 & 131.13 & 4210 & 51,883 \\
\hline NBG-18-3B & par 5 & perp & 1 & 40.86 & 181.75 & 0.16 & 4.243E-05 & 1.897 & 0.930 & 1.40 & 28.03 & 124.68 & 3826 & 57460 \\
\hline NBG-18-3B & par 6 & perp & 1 & 38.83 & 172.72 & 0.16 & $4.243 \mathrm{E}-05$ & 1.897 & 0.930 & 1.33 & 29.61 & 131.71 & 4641 & 60117 \\
\hline NBG-18-3B & par 7 & perp & 1 & 40.63 & 180.72 & 0.16 & $4.243 \mathrm{E}-05$ & 1.897 & 0.930 & 1.39 & 18.88 & 83.98 & 5045 & 64099 \\
\hline NBG-18-3B & par 8 & perp & 1 & 42.66 & 189.75 & 0.16 & $4.243 \mathrm{E}-05$ & 1.897 & 0.930 & 1.46 & 31.91 & 141.94 & 2393 & 46733 \\
\hline NBG-18-3B & par 9 & perp & 1 & 40.52 & 180.23 & 0.16 & 4.243E-05 & 1.897 & 0.930 & 1.39 & 20.47 & 91.05 & 11825 & 48650 \\
\hline NBG-18-3B & par 10 & perp & 1 & 42.42 & 188.68 & 0.16 & 4.243E-05 & 1.897 & 0.930 & 1.45 & 28.19 & 125.39 & 4091 & 55132 \\
\hline NBG-18-3B & par 11 & perp & 1 & 42.27 & 188.02 & 0.16 & $4.243 \mathrm{E}-05$ & 1.897 & 0.930 & 1.45 & 22.23 & 98.88 & 6423 & 52933 \\
\hline NBG-18-3B & par 12 & perp & 1 & 43.19 & 192.11 & 0.16 & $4.243 \mathrm{E}-05$ & 1.897 & 0.930 & 1.48 & 29.78 & 132.46 & 2253 & 71502 \\
\hline NBG-18-3B & par 13 & perp & 1 & 42.20 & 187.71 & 0.16 & $4.243 \mathrm{E}-05$ & 1.897 & 0.930 & 1.44 & 18.66 & 83.00 & 6490 & 62971 \\
\hline NBG-18-3B & par 14 & perp & 1 & 40.70 & 181.03 & 0.16 & 4.243E-05 & 1.897 & 0.930 & 1.39 & 31.86 & 141.71 & 3693 & 36406 \\
\hline NBG-18-3B & par 15 & perp & 1 & 40.03 & 178.05 & 0.16 & $4.243 \mathrm{E}-05$ & 1.897 & 0.930 & 1.37 & 30.98 & 137.80 & 6566 & 48518 \\
\hline NBG-18-3B & par 16 & perp & 1 & 41.66 & 185.30 & 0.16 & $4.243 \mathrm{E}-05$ & 1.897 & 0.930 & 1.43 & 31.02 & 137.98 & 3774 & 53527 \\
\hline NBG-18-3B & par 17 & perp & 1 & 41.86 & 186.19 & 0.16 & 4.243E-05 & 1.897 & 0.930 & 1.43 & 34.95 & 155.46 & 1300 & 37149 \\
\hline NBG-18-3B & par 18 & perp & 1 & 40.13 & 178.50 & 0.16 & $4.243 \mathrm{E}-05$ & 1.897 & 0.930 & 1.37 & 26.28 & 116.89 & 1193 & 62687 \\
\hline NBG-18-3B & par 19 & perp & 1 & 40.78 & 181.39 & 0.16 & $4.243 \mathrm{E}-05$ & 1.897 & 0.930 & 1.40 & 26.2 & 116.54 & 5590 & 60061 \\
\hline NBG-18-3B & par 20 & perp & 1 & 43.31 & 192.64 & 0.16 & $4.243 \mathrm{E}-05$ & 1.897 & 0.930 & 1.48 & 25.86 & 115.03 & 2316 & 53549 \\
\hline NBG-18-3B & par 21 & perp & 1 & 41.00 & 182.37 & 0.16 & 4.243E-05 & 1.897 & 0.930 & 1.40 & 11.52 & 51.24 & 3818 & 43040 \\
\hline NBG-18-3B & par 22 & perp & 1 & 40.19 & 178.77 & 0.16 & 4.243E-05 & 1.897 & 0.930 & 1.38 & 18.55 & 82.51 & 2775 & 44076 \\
\hline NBG-18-3B & par 23 & perp & 1 & 39.36 & 175.07 & 0.16 & $4.243 \mathrm{E}-05$ & 1.897 & 0.930 & 1.35 & 17.67 & 78.60 & 3676 & 44261 \\
\hline
\end{tabular}




\begin{tabular}{|c|c|c|c|c|c|c|c|c|c|c|c|c|c|c|}
\hline NBG-18-3B & par 24 & perp & 1 & 40.39 & 179.65 & 0.16 & 4.243E-05 & 1.897 & 0.930 & 1.38 & 30.31 & 134.82 & 3445 & 42021 \\
\hline NBG-18-3B & par 25 & perp & 1 & 40.70 & 181.03 & 0.16 & $4.243 \mathrm{E}-05$ & 1.897 & 0.930 & 1.39 & 30.56 & 135.93 & 1991 & 72604 \\
\hline & & & & $\begin{array}{c}\text { MEAN } \\
\text { S.D. }\end{array}$ & $\begin{array}{c}182.75 \\
6.56\end{array}$ & & & & & $\begin{array}{l}1.41 \\
0.05\end{array}$ & & $\begin{array}{c}116.20 \\
20.98\end{array}$ & $\begin{array}{l}4249 \\
2209\end{array}$ & $\begin{array}{l}54092 \\
10826\end{array}$ \\
\hline
\end{tabular}


Table $14 \mathrm{~K}_{\text {IIc }}$ data for grade PCEA, specimen cut parallel to billet long axis or extrusion direction

\begin{tabular}{|c|c|c|c|c|c|c|c|c|c|c|}
\hline \multicolumn{11}{|c|}{ PCEA Par specs (AG Notch should be tougher) } \\
\hline \multirow[b]{2}{*}{ Spec no } & \multirow[b]{2}{*}{ fracture comments } & \multirow{2}{*}{$\begin{array}{l}\text { Compressive } \\
\text { pert. (shear } \\
\text { force), lbs }\end{array}$} & \multirow{2}{*}{$\begin{array}{c}\text { Compressive } \\
\text { pert. (shear } \\
\text { force), } \mathrm{N}\end{array}$} & \multirow{2}{*}{$\begin{array}{c}\mathrm{H}=2 \mathrm{~h} \\
\mathrm{~mm}\end{array}$} & \multirow{2}{*}{$\begin{array}{c}W=2 w \\
m m\end{array}$} & \multirow{2}{*}{$\begin{array}{l}\mathrm{T}=2 \mathrm{t} \\
\mathrm{mm}\end{array}$} & \multirow{2}{*}{$\begin{array}{c}\sigma \mathrm{c}=\mathrm{F} /\left(\mathrm{w}^{*} \mathrm{~T}\right) \\
\mathrm{N} / \mathrm{mm}^{2}\end{array}$} & \multirow{2}{*}{$\begin{array}{c}\text { TADA'S EQUATION } \\
\text { Kiic }=(\sigma c / 4)^{*} \text { SQT }\left(\mathrm{Pi}^{*}{ }^{*} \text { E- }\right. \\
3) \\
\text { MPa.Vm }\end{array}$} & \multirow{2}{*}{$\begin{array}{c}2 \mathrm{a} \\
\mathrm{mm}\end{array}$} & \multirow{2}{*}{$\mathrm{a}$} \\
\hline & & & & & & & & & & \\
\hline PCEA-Block 2-Para-1 & Load pert. and $\mathrm{AE}$ & 39075 & 170043.3 & 100.13 & 130.18 & 50.09 & 52.15 & 2.54 & 24.20 & 12.10 \\
\hline PCEA-Block 2-Para-2 & $\mathrm{AE}$ & 33221.9 & 144572.3 & 100.13 & 130.15 & 50.10 & 44.34 & 2.16 & 24.15 & 12.08 \\
\hline PCEA-Block 2-Para-3 & $\mathrm{AE}$ & 36159.4 & 157355.4 & 100.12 & 130.12 & 50.02 & 48.35 & 2.35 & 24.14 & 12.07 \\
\hline PCEA-Block 2-Para-4 & Load pert. and $A E$ & 40375 & 175700.5 & 100.19 & 130.20 & 50.04 & 53.94 & 2.63 & 24.15 & 12.07 \\
\hline PCEA-Block 2-Para-5 & $\mathrm{AE}$ & 34687.5 & 150950.1 & 100.13 & 130.14 & 50.05 & 46.36 & 2.26 & 24.14 & 12.07 \\
\hline PCEA-Block 2-Para-6 & Load pert. and $\mathrm{AE}$ & 40968.8 & 178284.6 & 100.24 & 130.23 & 50.05 & 54.71 & 2.65 & 23.88 & 11.94 \\
\hline PCEA-Block 2-Para-7 & Load pert. and $A E$ & 43125 & 187667.8 & 100.15 & 130.12 & 50.00 & 57.69 & 2.81 & 24.11 & 12.05 \\
\hline PCEA-Block 2-Para-8 & Load pert. and $\mathrm{AE}$ & 33581 & 146135.0 & 100.15 & 130.13 & 50.05 & 44.88 & 2.18 & 24.11 & 12.05 \\
\hline PCEA-Block 2-Para-9 & Load perturbation & 38840.6 & 169023.3 & 100.17 & 130.16 & 50.06 & 51.88 & 2.53 & 24.13 & 12.06 \\
\hline PCEA-Block 2-Para-10 & Load pert. and $\mathrm{AE}$ & 36437.5 & 158565.7 & 100.18 & 130.21 & 50.01 & 48.70 & 2.37 & 24.07 & 12.03 \\
\hline PCEA-Block 2-Para-11 & NOT ANALYZED & & & 100.15 & 130.17 & 50.02 & & & 24.04 & 12.02 \\
\hline PCEA-Block 2-Para-12 & Load pert. and $A E$ & 40262.5 & 189882.8 & 100.13 & 130.19 & 50.01 & 58.33 & 2.83 & 23.98 & 11.99 \\
\hline PCEA-Block 2-Para-13 & Load pert. and $A E$ & 43634 & 189882.8 & 100.18 & 130.22 & 50.07 & 58.25 & 2.82 & 23.82 & 11.91 \\
\hline PCEA-Block 2-Para-14 & Load pert. and $A E$ & 34206.3 & 148856.1 & 100.15 & 130.12 & 50.02 & 45.74 & 2.22 & 24.05 & 12.03 \\
\hline PCEA-Block 2-Para-15 & Load pert. and $A E$ & 42934.8 & 186840.1 & 100.20 & 130.21 & 50.03 & 57.37 & 2.77 & 23.81 & 11.90 \\
\hline PCEA-Block 2-Para-16 & Load pert. and $\mathrm{AE}$ & 26900 & 117061.2 & 100.12 & 130.18 & 50.06 & 35.93 & 1.75 & 24.18 & 12.09 \\
\hline PCEA-Block 2-Para-17 & $\mathrm{AE}$ & 36965.6 & 160863.8 & 100.14 & 130.17 & 50.05 & 49.38 & 2.40 & 24.14 & 12.07 \\
\hline PCEA-Block 2-Para-18 & Load pert. and $A E$ & 39806.3 & 173225.7 & 100.22 & 130.25 & 50.06 & 53.14 & 2.57 & 23.83 & 11.92 \\
\hline PCEA-Block 3-Para-1 & Load pert. and $A E$ & 35003.9 & 152327.0 & 100.051 & 130.26 & 50.22 & 46.57 & 2.27 & 24.22 & 12.11 \\
\hline PCEA-Block 3-Para-2 & $\mathrm{AE}$ & 31185.4 & 135710.0 & 100.00 & 130.21 & 50.17 & 41.55 & 2.03 & 24.36 & 12.18 \\
\hline PCEA-Block 3-Para-3 & $\mathrm{AE}$ & 44858.1 & 195209.7 & 100.00 & 130.21 & 50.08 & 59.88 & 2.92 & 24.26 & 12.13 \\
\hline PCEA-Block 3-Para-4 & Load pert. and $\mathrm{AE}$ & 34463.1 & 149973.6 & 100.05 & 130.21 & 50.18 & 45.91 & 2.24 & 24.19 & 12.09 \\
\hline
\end{tabular}




\begin{tabular}{|c|c|c|c|c|c|c|c|c|c|c|}
\hline PCEA-Block 3-Para-5 & AE\&????? & 38914.4 & 169344.4 & 100.08 & 130.24 & 50.25 & 51.75 & 2.52 & 24.22 & 12.11 \\
\hline PCEA-Block 3-Para-6 & Load pert. and $A E$ & 43644 & 189926.3 & 100.04 & 130.25 & 50.18 & 58.12 & 2.84 & 24.26 & 12.13 \\
\hline PCEA-Block 3-Para-7 & NOT ANALYZED & & & 100.04 & 130.25 & 50.28 & & & 24.03 & 12.02 \\
\hline PCEA-Block 3-Para-8 & Load pert. and $A E$ & 39121.8 & 170247.0 & 100.10 & 130.19 & 50.20 & 52.11 & 2.53 & 24.00 & 12.00 \\
\hline PCEA-Block 3-Para-9 & Load pert. and $A E$ & 40371.8 & 175686.6 & 100.01 & 130.21 & 50.22 & 53.74 & 2.62 & 24.25 & 12.13 \\
\hline PCEA-Block 3-Para-10 & Load pert. and $A E$ & 39840.6 & 173375.0 & 100.01 & 130.21 & 50.12 & 53.13 & 2.58 & 24.06 & 12.03 \\
\hline PCEA-Block 3-Para-11 & NOT ANALYZED & & & 100.05 & 130.24 & 50.19 & & & 24.14 & 12.07 \\
\hline PCEA-Block 3-Para-12 & Load pert. and $A E$ & 41396.9 & 180147.6 & 99.99 & 130.22 & 50.09 & 55.24 & 2.68 & 24.05 & 12.02 \\
\hline PCEA-Block 3-Para-13 & $\mathrm{AE}$ & 37137.5 & 161611.9 & 100.05 & 130.27 & 50.22 & 49.41 & 2.41 & 24.15 & 12.08 \\
\hline PCEA-Block 3-Para-14 & Load pert. and $A E$ & 36840.6 & 160319.8 & 100.14 & 130.23 & 50.19 & 49.06 & 2.38 & 23.95 & 11.98 \\
\hline PCEA-Block 3-Para-15 & Load pert. and $A E$ & 31306.3 & 136236.1 & 100.11 & 130.97 & 50.20 & 41.45 & 2.01 & 23.92 & 11.96 \\
\hline PCEA-Block 3-Para-16 & Load pert. and $A E$ & 37446.9 & 162958.3 & 100.14 & 130.09 & 50.21 & 49.90 & 2.42 & 23.92 & 11.96 \\
\hline PCEA-Block 3-Para-17 & Load pert. and $A E$ & 36778.1 & 160047.8 & 100.18 & 130.26 & 50.13 & 49.02 & 2.38 & 24.02 & 12.01 \\
\hline PCEA-Block 3-Para-18 & Load perturbation & 35396.9 & 154037.3 & 100.19 & 130.13 & 50.18 & 47.18 & 2.29 & 23.96 & 11.98 \\
\hline PCEA-Block 4-Para-1 & Load perturbation & 38415.6 & 167173.8 & 99.99 & 130.22 & 50.15 & 51.20 & 2.49 & 24.01 & 12.00 \\
\hline PCEA-Block 4-Para-2 & Load pert. and $A E$ & 32356.3 & 140805.4 & 100.01 & 130.23 & 50.17 & 43.10 & 2.10 & 24.13 & 12.07 \\
\hline PCEA-Block 4-Para-3 & Load pert. and $A E$ & 34678.1 & 150909.2 & 99.85 & 130.21 & 50.15 & 46.22 & 2.26 & 24.42 & 12.21 \\
\hline PCEA-Block 4-Para-4 & NOT ANALYZED & & & 99.86 & 130.23 & 50.19 & & & 24.41 & 12.21 \\
\hline PCEA-Block 4-Para-5 & Load perturbation & 33156.3 & 144286.8 & 100.02 & 130.23 & 50.18 & 44.16 & 2.15 & 24.13 & 12.06 \\
\hline PCEA-Block 4-Para-6 & Load pert. and $A E$ & 38415.6 & 167173.8 & 100.02 & 130.25 & 50.16 & 51.17 & 2.49 & 24.06 & 12.03 \\
\hline PCEA-Block 4-Para-7 & Load pert. and $A E$ & 33403.1 & 145360.8 & 99.84 & 130.26 & 50.15 & 44.50 & 2.18 & 24.47 & 12.24 \\
\hline PCEA-Block 4-Para-8 & Load pert. and $A E$ & 38496.9 & 167527.6 & 99.99 & 130.21 & 50.15 & 51.31 & 2.49 & 24.04 & 12.02 \\
\hline PCEA-Block 4-Para-9 & Load pert. and $A E$ & 34487.5 & 150079.8 & 100.04 & 130.27 & 50.17 & 45.93 & 2.24 & 24.13 & 12.06 \\
\hline PCEA-Block 4-Para-10 & Load perturbation & 36678.1 & 159612.7 & 99.99 & 130.20 & 50.18 & 48.87 & 2.38 & 24.13 & 12.07 \\
\hline PCEA-Block 4-Para-11 & NOT ANALYZED & & & 99.85 & 130.21 & 50.14 & & & 24.44 & 12.22 \\
\hline PCEA-Block 4-Para-12 & $\mathrm{AE}$ & 33706.3 & 146680.2 & 100.00 & 130.18 & 50.19 & 44.90 & 2.19 & 24.12 & 12.06 \\
\hline PCEA-Block 4-Para-13 & Load perturbation & 39671.9 & 172640.8 & 99.80 & 130.24 & 50.18 & 52.84 & 2.59 & 24.54 & 12.27 \\
\hline PCEA-Block 4-Para-14 & $\mathrm{AE}$ & 38409.4 & 167146.8 & 100.01 & 130.24 & 50.20 & 51.13 & 2.48 & 23.98 & 11.99 \\
\hline PCEA-Block 4-Para-15 & Load perturbation & 33721.9 & 146748.1 & 100.00 & 130.19 & 50.19 & 44.92 & 2.19 & 24.23 & 12.12 \\
\hline PCEA-Block 4-Para-16 & $\mathrm{AE}$ & 46500 & 202354.8 & 100.00 & 130.20 & 50.16 & 61.97 & 3.02 & 24.16 & 12.08 \\
\hline
\end{tabular}




\begin{tabular}{|c|c|c|c|c|c|c|c|c|c|c|}
\hline PCEA-Block 4-Para-17 & Load pert. and $\mathrm{AE}$ & 41156.3 & 179100.5 & 99.97 & 130.19 & 50.20 & 54.81 & 2.67 & 24.08 & 12.04 \\
\hline PCEA-Block 4-Para-18 & Load pert. and $\mathrm{AE}$ & 39078.1 & 170056.8 & 99.85 & 130.21 & 50.19 & 52.04 & 2.54 & 24.28 & 12.14 \\
\hline
\end{tabular}


Table $15 \mathrm{~K}_{\text {IIC }}$ data for PCEA, specimens cut perpendicular to the billet long axis or extrusion direction

\begin{tabular}{|c|c|c|c|c|c|c|c|c|c|c|}
\hline & & $\begin{array}{c}\text { Compressi } \\
\text { ve pert. }\end{array}$ & $\begin{array}{c}\text { Compressi } \\
\text { ve pert. }\end{array}$ & $\mathrm{H}=2 \mathrm{~h}$ & $W=2 w$ & $T=2 t$ & $\begin{array}{c}\sigma c=F /( \\
\left.w^{*} T\right)\end{array}$ & $\begin{array}{c}\text { TADA'S EQUATION } \\
\text { Kiic }=(\sigma c / 4) * S Q T(P i \\
* a * E-3)\end{array}$ & $2 a$ & a \\
\hline Spec no & Fracture comments & $\begin{array}{c}\text { (shear } \\
\text { force), lbs }\end{array}$ & $\begin{array}{c}\text { (shear } \\
\text { force), N }\end{array}$ & $\mathrm{mm}$ & $\mathrm{mm}$ & $\mathrm{mm}$ & $\begin{array}{c}\mathrm{N} / \mathrm{mm} \\
2 \\
\end{array}$ & MPa.Vm & $\mathrm{mm}$ & $\mathrm{mm}$ \\
\hline PCEA-Block 1-Perp-1 & Load perturbation & 33437.5 & 145510.5 & 100.13 & 130.18 & 50.09 & 44.63 & 2.18 & 24.20 & 12.10 \\
\hline PCEA-Block 1-Perp-2 & $\mathrm{AE}$ & 31625 & 137623.0 & 100.13 & 130.15 & 50.10 & 42.21 & 2.06 & 24.15 & 12.08 \\
\hline PCEA-Block 1-Perp-3 & $\begin{array}{l}\text { Load pert. } \\
\text { \& AE (??) }\end{array}$ & 30450 & 132509.8 & 100.12 & 130.12 & 50.02 & 40.72 & 1.98 & 24.14 & 12.07 \\
\hline PCEA-Block 1-Perp-4 & $\begin{array}{l}\text { Load pert. } \\
\& A E \text { (??) }\end{array}$ & 27940.6 & 121589.6 & 100.19 & 130.20 & 50.04 & 37.33 & 1.82 & 24.15 & 12.07 \\
\hline PCEA-Block 1-Perp-5 & $\mathrm{AE}$ & 29884.4 & 130048.4 & 100.13 & 130.14 & 50.05 & 39.94 & 1.94 & 24.14 & 12.07 \\
\hline PCEA-Block 1-Perp-6 & $\begin{array}{l}\text { Load pert. } \\
\& A E \text { (??) }\end{array}$ & 33493.8 & 145755.5 & 100.24 & 130.23 & 50.05 & 44.73 & 2.17 & 23.88 & 11.94 \\
\hline PCEA-Block 2-Perp-1 & Load pert. \& AE & 39075 & 170043.3 & 100.15 & 130.12 & 50.00 & 52.27 & 2.54 & 24.11 & 12.05 \\
\hline PCEA-Block 2-Perp-2 & $\mathrm{AE}$ (??) & 32765.6 & 142586.6 & 100.15 & 130.13 & 50.05 & 43.79 & 2.13 & 24.11 & 12.05 \\
\hline PCEA-Block 2-Perp-3 & $\begin{array}{l}\text { Load pert. } \\
\text { \& AE (??) }\end{array}$ & 36175 & 157423.3 & 100.17 & 130.16 & 50.06 & 48.32 & 2.35 & 24.13 & 12.06 \\
\hline PCEA-Block 2-Perp-4 & Load pert. \& AE & 32509.4 & 141471.7 & 100.18 & 130.21 & 50.01 & 43.45 & 2.11 & 24.07 & 12.03 \\
\hline PCEA-Block 2-Perp-5 & $\begin{array}{l}\text { Load pert. } \\
\text { \& AE (??) }\end{array}$ & 31521.9 & 137174.4 & 100.15 & 130.17 & 50.02 & 42.13 & 2.05 & 24.04 & 12.02 \\
\hline PCEA-Block 2-Perp-6 & Load pert. \& AE & 32746.9 & 142505.2 & 100.13 & 130.19 & 50.01 & 43.77 & 2.12 & 23.98 & 11.99 \\
\hline PCEA-Block 3-Perp-1 & $\begin{array}{l}\text { Load pert. } \\
\& A E \text { (??) }\end{array}$ & 33143.8 & 144232.4 & $\begin{array}{c}100.05 \\
1 \\
\end{array}$ & 130.26 & 50.22 & 44.10 & 2.15 & 24.22 & 12.11 \\
\hline PCEA-Block 3-Perp-2 & $\mathrm{AE}$ & 32350 & 140778.0 & 100.00 & 130.21 & 50.17 & 43.10 & 2.11 & 24.36 & 12.18 \\
\hline PCEA-Block 3-Perp-3 & $\begin{array}{l}\text { Load pert. } \\
\& A E \text { (??) }\end{array}$ & 36643.8 & 159463.4 & 100.00 & 130.21 & 50.08 & 48.91 & 2.39 & 24.26 & 12.13 \\
\hline PCEA-Block 3-Perp-4 & Load pert. \& AE & 33456.3 & 145592.3 & 100.05 & 130.21 & 50.18 & 44.57 & 2.17 & 24.19 & 12.09 \\
\hline
\end{tabular}




\begin{tabular}{|c|c|c|c|c|c|c|c|c|c|c|}
\hline PCEA-Block 3-Perp-5 & $\begin{array}{l}\text { Load pert. } \\
\& A E \text { (??) }\end{array}$ & 35806.3 & 155818.8 & 100.08 & 130.24 & 50.25 & 47.62 & 2.32 & 24.22 & 12.11 \\
\hline PCEA-Block 3-Perp-6 & $\begin{array}{l}\text { Load pert. } \\
\text { \& AE (??) }\end{array}$ & 33946.9 & 147727.3 & 100.04 & 130.25 & 50.18 & 45.20 & 2.21 & 24.26 & 12.13 \\
\hline PCEA-Block 4-Perp-1 & $\mathrm{AE}$ & 36509.4 & 158878.5 & 99.99 & 130.22 & 50.15 & 48.66 & 2.36 & 24.01 & 12.00 \\
\hline PCEA-Block 4-Prep-2 & $\begin{array}{l}\text { Load pert. } \\
\& A E \text { (??) }\end{array}$ & 32909.4 & 143212.4 & 100.01 & 130.23 & 50.17 & 43.84 & 2.13 & 24.13 & 12.07 \\
\hline PCEA-Block 4-Perp-3 & $\begin{array}{c}\text { Load } \\
\text { perturbation?? }\end{array}$ & 39334.4 & 171172.1 & 99.85 & 130.21 & 50.15 & 52.43 & 2.57 & 24.42 & 12.21 \\
\hline PCEA-Block 4-Perp-4 & $\begin{array}{l}\text { Load pert. } \\
\text { \& AE (??) }\end{array}$ & 38751.1 & 168633.8 & 99.86 & 130.23 & 50.19 & 51.60 & 2.53 & 24.41 & 12.21 \\
\hline PCEA-Block 4-Perp-5 & $\begin{array}{l}\text { Load pert. } \\
\text { \& AE (??) }\end{array}$ & 34612.5 & 150623.8 & 100.02 & 130.23 & 50.18 & 46.09 & 2.24 & 24.13 & 12.06 \\
\hline PCEA-Block 4-Perp-6 & $\begin{array}{l}\text { Load pert. } \\
\text { \& AE (??) }\end{array}$ & 35968.8 & 156526.0 & 100.02 & 130.25 & 50.16 & 47.91 & 2.33 & 24.06 & 12.03 \\
\hline & Mean & & 147787.5 & & & & & 2.21 & & \\
\hline & St. Dev. & & 12545.4 & & & & & 0.19 & & \\
\hline
\end{tabular}


Table $16 \mathrm{~K}_{\text {IIc }}$ data for IG-110, isostatically pressed fine-grained graphite

\begin{tabular}{|c|c|c|c|c|c|c|c|c|c|c|}
\hline \multicolumn{11}{|c|}{ E IG-110 } \\
\hline \multirow{2}{*}{$\begin{array}{c}\text { Spec } \\
\text { no }\end{array}$} & \multirow[b]{2}{*}{ Fracture comments } & \multirow{2}{*}{$\begin{array}{c}\text { Compressive } \\
\text { perturbation } \\
\text { (shear force), } \\
\text { Ibs }\end{array}$} & \multirow{2}{*}{$\begin{array}{c}\text { Compressive } \\
\text { perturbation } \\
\text { (shear } \\
\text { force), } \mathrm{N} \\
\end{array}$} & $\mathrm{H}=2 \mathrm{~h}$ & $W=2 w$ & $T=2 t$ & $\begin{array}{c}\sigma c=F /(w \\
* T)\end{array}$ & $\begin{array}{c}\text { TADA'S EQUATION } \\
\text { Kiic }=(\sigma c / 4)^{*} \text { SQT }\left(P^{*}{ }^{*} *\right. \\
\text { E-3) }\end{array}$ & $2 a$ & a \\
\hline & & & & $\mathrm{mm}$ & $\mathrm{mm}$ & $\mathrm{mm}$ & $\mathrm{N} / \mathrm{mm} 2$ & $\mathrm{MPa} . \mathrm{Vm}$ & $\mathrm{mm}$ & $\mathrm{mm}$ \\
\hline E1 & Load pert. and $\mathrm{AE}$ & 43356.3 & 188674.3 & 100.79 & 130.01 & 50.01 & 58.04 & 2.86 & 24.82 & 12.41 \\
\hline E2 & Load pert. and $\mathrm{AE}$ & 43456.3 & 189109.5 & 100.69 & 130.02 & 50.02 & 58.16 & 2.86 & 24.66 & 12.33 \\
\hline E3 & Load pert. and $A E$ & 44415.6 & 193284.1 & 100.76 & 130.00 & 50.02 & 59.45 & 2.93 & 24.76 & 12.38 \\
\hline E4 & Load pert. and $A E$ & 40746.9 & 177318.9 & 100.88 & 130.03 & 50.02 & 54.52 & 2.70 & 24.90 & 12.45 \\
\hline E5 & Load pert. and $A E$ & 46015.6 & 200246.8 & 100.76 & 130.03 & 50.00 & 61.61 & 3.03 & 24.68 & 12.34 \\
\hline E6 & Load pert. and $A E$ & 43496.9 & 189286.2 & 100.74 & 130.02 & 49.97 & 58.27 & 2.87 & 24.75 & 12.37 \\
\hline E7 & Load pert. and $\mathrm{AE}$ & 42881.3 & 186607.2 & 100.06 & 130.08 & 49.90 & 57.49 & 2.80 & 24.15 & 12.07 \\
\hline E8 & NOT ANALYSED & & & 100.76 & 130.08 & 50.15 & & & 24.81 & 12.40 \\
\hline E9 & Load pert. and $\mathrm{AE}$ & 47768.8 & 207876.3 & 100.68 & 130.03 & 49.96 & 64.00 & 3.15 & 24.69 & 12.34 \\
\hline E10 & Load pert. and $A E$ & 42325 & 184186.4 & 99.96 & 130.05 & 50.02 & 56.64 & 2.75 & 23.94 & 11.97 \\
\hline E11 & Load pert. and $\mathrm{AE}$ & 42640.6 & 185559.8 & 100.02 & 130.20 & 50.05 & 56.95 & 2.78 & 24.32 & 12.16 \\
\hline E12 & Load pert. and $\mathrm{AE}$ & 38846.9 & 169050.7 & 100.03 & 130.02 & 50.03 & 51.98 & 2.52 & 24.01 & 12.00 \\
\hline E13 & Load pert. and $A E$ & 40387.5 & 175754.9 & 100.01 & 130.03 & 50.09 & 53.97 & 2.63 & 24.10 & 12.05 \\
\hline E14 & Load pert. and $A E$ & 35406.3 & 154078.2 & 99.99 & 130.05 & 50.04 & 47.35 & 2.30 & 24.11 & 12.05 \\
\hline $\mathrm{E} 15$ & Load pert. and $A E$ & 30256.3 & 131666.8 & 99.97 & 130.14 & 50.04 & 40.44 & 1.97 & 24.11 & 12.06 \\
\hline E16 & Load pert. and $\mathrm{AE}$ & 42406.3 & 184540.2 & 100.75 & 130.08 & 50.07 & 56.67 & 2.79 & 24.73 & 12.36 \\
\hline E17 & Load pert. and $\mathrm{AE}$ & 40403.1 & 175822.8 & 100.81 & 130.12 & 49.98 & 54.07 & 2.67 & 24.89 & 12.45 \\
\hline E18 & Load pert. and $\mathrm{AE}$ & 40240.6 & 175115.7 & 100.73 & 130.04 & 50.03 & 53.84 & 2.65 & 24.66 & 12.33 \\
\hline E19 & Load pert. and $\mathrm{AE}$ & 39075 & 170043.3 & 99.99 & 130.03 & 50.33 & 51.97 & 2.51 & 23.81 & 11.91 \\
\hline E20 & Load pert. and $A E$ & 40403.1 & 175822.8 & 99.88 & 130.08 & 50.10 & 53.97 & 2.62 & 23.94 & 11.97 \\
\hline E21 & Load pert. and $A E$ & 44340.6 & 192957.7 & 100.84 & 130.04 & 50.07 & 59.28 & 2.93 & 24.81 & 12.41 \\
\hline E22 & Load pert. and $A E$ & 41171.9 & 179168.4 & 100.02 & 130.02 & 50.05 & 55.07 & 2.67 & 23.93 & 11.96 \\
\hline
\end{tabular}




\begin{tabular}{|c|c|c|c|c|c|c|c|c|c|c|}
\hline E23 & load perturbation & 36103.1 & 157110.4 & 99.99 & 130.01 & 50.14 & 48.21 & 2.34 & 23.98 & 11.99 \\
\hline E24 & Load pert. and $A E$ & 44062.5 & 191747.5 & 100.03 & 130.05 & 50.06 & 58.91 & 2.88 & 24.26 & 12.13 \\
\hline E25 & Load pert. and $A E$ & 42631.3 & 185519.3 & 100.01 & 130.02 & 50.13 & 56.93 & 2.77 & 24.06 & 12.03 \\
\hline E26 & Load pert. and $A E$ & 35943.8 & 156417.2 & 99.98 & 130.09 & 50.10 & 48.00 & 2.34 & 24.13 & 12.07 \\
\hline E27 & Load pert. and $A E$ & 42175 & 183533.6 & 99.97 & 130.05 & 50.21 & 56.21 & 2.73 & 23.98 & 11.99 \\
\hline & Mean & & 190214.9 & & & & & 2.87 & & \\
\hline & St. Dev. & & 8587.9 & & & & & 0.14 & & \\
\hline
\end{tabular}




\section{REFERENCES}

${ }^{1}$ T. D. Burchell, Proc. CARBONE 90, International Carbon Conference, pp.278-279, Paris, France, July 16-20, 1990

${ }^{2}$ G. R. Romanoski and T. D. Burchell, In Proc. $20^{\text {th }}$ Biennial Conference on Carbon, pp 584-585, University of California, Santa Barbara, CA., July 23-28 1991

${ }^{3}$ D7779 - 11 "Standard Test Method for Determination of Fracture Toughness at Ambient Temperature". Annual Book of ASTM Standards, Vol. 5.05, Petroleum Product, Lubricants, and Fossil Fuels, p. 832. Pub. ASTM International, West Conshohocken, PA (2016)

${ }^{4}$ D7219- 08 "Standard Specification for Isotropic and Near-Isotropic Nuclear Graphite". Annual Book of ASTM Standards, Vol. 5.05, Petroleum Product, Lubricants, and Fossil Fuels, p. 802. Pub. ASTM International, West Conshohocken, PA (2016)

${ }^{5}$ D7301 - 11 "Standard Specification for Components Subjected to Low Neutron Irradiation Dose". Annual Book of ASTM Standards, Vol. 5.05, Petroleum Product, Lubricants, and Fossil Fuels, p. 807. Pub. ASTM International, West Conshohocken, PA (2016)

${ }^{6}$ Tim Burchell and Joe Strizak, ORNL/TM-2011/497, Post Irradiation Examination data for PCEA graphite Irradiated at $900^{\circ} \mathrm{C}$ in HFIR, May 2012

${ }^{7}$ T. Burchell and J. Strizak, "The effect of neutron irradiation on the fracture toughness of graphite", Nuclear Engineering and Design 271 (20140 262-269

${ }^{8}$ Hui Yang, He Li, Lihong Zhu, Dai Huang, Houzeng Wu, Mary Snead, Anne A. Campbell, Yutai Katoh and Timothy D. Burchell. International Nuclear Graphite Specialists Meeting, INGSM-17, Vienna, Austria, September $5-8,2016$

${ }^{9}$ Vallen Systeme, Acoustic Emission Sensors Specification Released Germany Dec. 2012, http://www.vallen.de

${ }^{10}$ T. D. Burchell, R. G. Cooke, B. McEnaney and I. M. Pickup. "Acoustic Emission from Graphite - the Effect of Texture. In Ext. Abs. \& Prog. Carbone 84, Bordeaux, France. July 2-6,(1984) p.110.

11 T. D. Burchell, R. G. Cooke, B. McEnaney and I. M. Pickup. "Acoustic Emission from Polygranular Graphite grades" Carbon 23 (1985) 739-747.

12 G. R. Romanoski and T. D. Burchell, Chpt. 14:" Fracture in Graphite" In T. D. Burchell (Editor) Carbon Materials for Advanced Technologies, pp. 485-534 (1999)

${ }^{13}$ ORNL/TM-2014/614, Timothy D. Burchell and Don Erdmann III, The Shear Fracture Toughness (KIIc) of Graphite Dec. 2014

14 Timothy D. Burchell, Don Erdmann III. “The shear fracture toughness, $K_{I I c}$, of graphite”, Carbon 98 (2016) $267-$ 279

15 D. K. Shetty, Mixed-Mode Fracture Criteria for Reliability Analysis and Design with Structural Ceramics, Trans ASME J. Eng. Gas Turbines Power 109 (3) (1987) 282-289

${ }^{16}$ C565 - 93 (reapproved 2010) "Standard Test Method for Tension Testing of Carbon and Graphite Mechanical Materials". Annual Book of ASTM Standards, Vol. 5.05, Petroleum Product, Lubricants, and Fossil Fuels, p. 710. Pub. ASTM International, West Conshohocken, PA (2016)

${ }^{17}$ C7490 - 15"Standard Test Method for Tensile Stress-Strain of Carbon or Graphite". Annual Book of ASTM Standards, Vol. 5.05, Petroleum Product, Lubricants, and Fossil Fuels, p. 710. Pub. ASTM International, West Conshohocken, PA (2016) 